PSIKOPEDAGOGIA, Vol. 1, No. 1, Juni 2012

ISSN: 2301-6167

\title{
ETOS PENDIDIKAN DAN KESEJAHTERAAN MIGRAN MUSLIM STUDI KASUS DI PEMUKIMAN MIGRAN PANGKOH KAB. PULANG PISAU PROVINSI KALIMANTAN TENGAH
}

\section{ETHOS EDUCATION AND WELFARE OF MIGRANT MUSLIM CASE STUDIES MIGRAN SETTLEMENT PANGKOH IN PULANG PISAU CENTRAL KALIMANTAN PROVINCE}

\author{
H. Abdul Qodir \\ Universitas Ahmad Dahlan \\ Email: sriwidaryati@ymail.com
}

\begin{abstract}
Abstrak
Masyarakat transmigran muslim di Pangkoh banyak berhasil di bidang pendidikan, bekerja, dan kehidupan lebih baik pada dasawarsa III (2002-2011). Padahal, pada awal tiba dasawarsa I (1982-1991), sebagian kecil memiliki pendidikan menengah, sebagian besar tamat SD, sетиа memulai kehidupan baru. MasaIahnya difokuskan pada etos pendidikan dan kesejahteraan. Penelitian ini bersifat deskriptif kualitatif, yang erat kaitannya dengan penelitian budaya. Pendekatan penelitian yang digunakan adalah etnografi dalam upaya memahami etos menempuh pendidikan dan mencapai kesejahteraan pada masyarakat migran Pangkoh. Subjek penelitian adalah orang migran muslim Pangkoh. Dalam pengumpulan data, menggunakan teknik utama adalah wawancara mendalam dan pengamatan yang kait dengan permasalahan. Analisis data dilakukan secara kualitatif yaitu dengan cara melakukan deskripsi secara naratif dan interpretatif terhadap fenomena etos dan kesejahteraan yang telah ditemukan pada keluarga migran muslim yang diteliti. Penelitian ini menunjukkan bahwa, pertama,masyarakat migran muslim pada awal tiba (1982) yang berpendidikan menengah atau sedikit lebih tinggi pada dasa warsa II meningkat dengan menempuh sampai sarjana S.1 untuk dirinya sendiri dan keluarga. Pekerjaan pokok beberapa migran muslim kelompok ini meningkat pada kepangkatan dan tugas memimpin sekolah. Peningkatan pendapatan dari tunjangan sertifikasi pendidik dan tunjangan memimpin. Kedua, masyarakat migran muslim yang awal kedatangannya berpendidikan dasar, sekolah dasar atau yang sederajat, memiliki etos pendidikan yang tidak langsung, dalam tiga dasawarsa.
\end{abstract}

Kata kunci:etos pendidikan, sejahtera, migran muslim

\begin{abstract}
Muslim migrants in society Pangkoh much success in the field of education, work, and life is better in the third decade (2002-2011). In fact, at the beginning of the decade arrived I (19821991), a small portion has a secondary education, the majority of elementary school, all start a new life. Masalahnya ethos is focused on education and welfare. This research is descriptive qualitative, which is closely related to cultural studies. The approach used in this study is ethnography in an effort to understand the ethos of education and prosper in migrant communities Pangkoh. Subjects were Pangkoh Muslim migrants. In collecting the data, using primary techniques are in-depth interviews and observations hooks with problems. The data were analyzed qualitatively ie by way of narrative and interpretive description of the phenomenon and welfare ethos that has been found in the Muslim migrant families studied. This study shows that, first, the Muslim migrant communities in the early arriving (1982) educated middle or slightly higher in the second decade increased by taking up a bachelor S.1 for himself and family. The principal work of this group some Muslim migrants increased in rank and the task of leading the school. Increased revenue from the allowances and benefits lead educator certification. Second, Muslim migrant communities that early arrival basic education, primary school or its equivalent, has the educational ethos that indirectly, in three decades.
\end{abstract}

Keywords: ethos of education, welfare, immigrant Muslims 


\section{PENDAHULUAN}

Transmigrasi atau migrasi merupakan hal yang menarik untuk dipelajari, karena dampak positif transmigrasi tampak nyata dapat dirasakan oleh keluarga dan masyarakat secara khusus, dan pemerintah pada umumnya.

Program transmigrasi merupakan program pemerintah yang bertujuan membuat rakyat lebih hutan primer dan hutan primer yang akan ditebangi. Tujuan utama dan program transmigrasi ini adalah menyediakan lokasi pemukiman bagi 15 juta orang lebih hingga pada akhir abad xxi. Lihat Repetto, Robert C., Public Policies and the Misuse of Forest Resources (Cambridge United Kingdom Academic [u.a.]: Cambridge Univ. Press, 1988), him. 77. Lihat pula Kebschull, Dietrich, Transmigration in Indonesia: An Empirical Analysis of Motivation, Expectations, dan Experiences (Hamburg: Verlag Weltarchive, 1986), hlm. 88-144. sejahtera. Program ini, nampaknya tidak hanya didanai pemerintah saja, tetapi Bank dunia pun ikut berpartisipasi karena keuntungankeuntungan yang diharapkan akan diperoleh setelah program transmigrasi berjalan. Tanah-tanah di daerah transmigran nampaknya banyak yang digunakan untuk tanah pertanian. Sejak zaman kolonial sampai sekarang nampak peningkatan dalam pemanfaatan tanah di daerah transmigran. Sistem transmigrasi dari satu pulau ke lain pulau berbeda. Misalnya daerah Kalimantan yang banyak memiliki sungai, dan transportasi yang banyak dilakukan melewati jalur air daripada jalur darat kecuali pada musim kemarau jalan darat lebih berfungsi.

Transmigrasi pun bermanfaat untuk petani lokal, maupun daerah asal. Daerah asal menjadi lebih lapang, baik dari segi tanah maupun rezeki, karena para transmigran sering mendatangkan rezeki dengan kiriman-kiriman mereka. Kepadatan daerah, misalnya dengan apa yang terjadi di Jawa, akan membahayakan tanah dan sistem pengairan, bahkan kehidupan manusia secara umum. Sedimentasi dan banjir di daerah aliran sungai telah menjadi ancaman yang serius. Keinginan pemerintah untuk meningkatkan taraf hidup nampaknya membuahkan hasil. Banyak transmigran yang mengalami peningkatan dalam kehidupan mereka. Mereka yang tadinya tidak mampu bersekolah atau melanjutkan ke perguruan tinggi dapat menyekolahkan anak-anak mereka hingga perguruan tinggi, dan mendapatkan pekerjaan yang sesuai dengan pendidikan mereka.

Anak-anak transmigran nampak hidup lebih baik dan makmur dibandingkan keadaan mereka sebelum mereka melakukan transmigrasi. Para transmigran yang hidup pas-pasan pun berusaha agar mereka memperoleh kehidupan yang lebih baik, bagi anak maupun orang tua dengan mengirim anak untuk belajar. Sebagaimana terjadi di belahan lain negara-negara di dunia, pendidikan masih dianggap hal penting di antara mereka yang berhijrah atau migrasi.

Tulisan berikut ini cukup mewakili apa yang terjadi di kalangan para transmigran di Indonesia.

Children's education is also very important to Mexican migrant workers. For many, the fact that they can send their children to School is a source of great pride. Not having had an opportunity to go to school themselves, many of them feel that they owe it to their children to do everything possible to better prepare them to compete for jobs.

Bahkan umumnya putra-putri transmigran memiliki jenjang pendidikan yang lebih tinggi dibandingkan dengan mereka yang tidak bertransmigrasi dan tetap tinggal di daerah asal, sebagaimana pernyataan berikut ini :

on the positive side, the children of immigrants showed no sign of "second generation decline". Most members of the second generation were attaining much more education than their parents and 
surprassing their native born minority counterparts. ${ }^{\circ}$

Pengamatan penulis terhadap hasilhasil ujian semester, kualitas penulisan skripsi, ketepatan waktu penyelesaian studi mahasiswa pada jenjang strata 1 dan perbincangan dengan sesama staf pengajar, semakin jelas fenomena keberhasilan mahasiswa anak transmigran, yang umumnya berbudaya Jawa dibanding mahasiswa non-transmigran yang muslim." Selain fenomena keberhasilan menempuh pendidikan, merekapun memiliki civic commitment yang tinggi, sebagaimana dapat dijumpai pada kelompok migran di negara lain.

Dengan ungkapan lain, mahasiswa anak transmigran pada umumnya (meskipun tidak seluruhnya) menunjukan tingkat keberhasilan belajar/studi yang lebih tinggi dibanding mahasiswa lain.

Sementara itu, berdasarkan pengamatan, banyak di antara mahasiswa anak migran hidup dengan keterbatasan ekonomi dan juga bukan berasal dari keluarga yang orang tuanya berpendidikan tinggi.

Hal ini bertentangan dengan hasil penelitian yang dilakukan Weis yang dipublikasikan pada tahun 1979, bahwa di Kenya, Ghana dan Nigeria rnahasiswa di universitas dan siswa pada akhir sekolah menengah alas nampaknya lcbih banyak dari kelompok rumah tangga berpendidikan.Apa implikasi dari hasil penelitian Weis ini? Apakah ini berarti bahwa mereka yang tidak berasal dari keluarga elit akan berpenampilan buruk di sekolah?

Pernyataan dalam hasil riset Weis ini berbeda dengan apa yang terjadi di lingkungan individu keluarga tranmigran muslim Pangkoh maupun temuan Lake dalam penelitian yang dipublikasikan Sian. Sian pernah mengutarakan penelitian Lake yang menunjukkan bahwa anak-anak yang miskin tidak selalu lebih buruk daripada mereka yang kaya atau hidup berkecukupan.
Anak-anak dari keluarga transmigrani muslim asal Pangkoh teramati memiliki kebiasaan yang unik dalam menempuh pendidikan atau ketika kembali ke desanya, sebagian besar dari mereka memiliki kebiasaan bekerja part time, mandiri dan tidak banyak membebani orang tua ketika merantau berkuliah, terutama mereka yang berasal dari keluarga migran yang petani, pedagang, perajin, peternak dan guru honorer. Banyak anak migran terlihat bersungguh-sungguh membantu pekerjaan orang tua setiap sore hari, seperti mengambil rumput dan memboncengkannya pada sepeda motor untuk ternak piaraan ayahnya selama berlibur kuliah atau usai sekolah di Pangkoh tanpa menampakkan rasa malu sedikitpun meskupun mereka pernah hidup di kota.

Sedikit berbeda dengan anak migran muslim yang berasal dari keluarga pejabat lokal seperti kepala desa, kepala KUA, kepala sekolah atau abdi negara, oleh karena itu, teramati ada tiga (3) fenomena atau gejala etos pada masyarakat Pangkoh pada observasi awal kepada beberapa keluarga migran, dengan gambaran fenomena sebagai berikut:

Fenomena yang pertama adalah beberapa kepala keluarga muslim yang menyekolahkan dan menguliahkan semua anaknya, memandang pendidikan lebih penting, krusial, mendesak dan harus didahulukan daripada aktivitas yang lain. Kelompok ini menyikapi peluang pendidikan secara positif, sehingga merasa harus mencari dan mengalokasikan dana untuk pendidikan dirinya dan anak-anaknya, selain untuk memenuhi kebutuhan pokok keluarga. Individu yang mempunyai sikap demikian ini adalah orang tua yang memiliki pendidikan, bekerja sebagai guru, petanipetani pemilik, atau beberapa keluarga swasta yang mempunyai penghasilan relatif banyak. Fenomena kedua, terlihat beberapa keluarga transmigran muslim yang tidak mempunyai penghasilan tetap, akan tetapi 
suka menyekolahkan atau menguliahkan hampir semua anaknya dan bekerja menjadi guru abdi negara, dosen dan menjadi polisi. Mereka, menggunakan penghasilan yang dikumpulkan dari basil bertani, berternak, berkebun untuk pendidikan anaknya, tetapi terkendala pendanaan karena volume penghasilan yang tidak menentu tanggal dan bulan serta jumlahnya penghasilan. Fenomena yang ketiga adalah keluarga yang menyikapi anak-anak secara permisif dan memberi alternatif kerja membantu usaha yang telah dirintis orangtua, fenomena ini berkembang pada keluarga yang kerja swasta, termasuk pekerja pada jasa angkutan, buruh tani, pedagang hasil-hasil tanaman palawija.

Pada fenomena-fenomena satu sampai tiga seperti disebut di atas diduga terdapat spirit (ethos) yang bervariasi, salah satunya adalah etos pendidikan. Fenomena itu, menurut sudut-pandang psikologi terdapat persoalan yang menarik dikaji untuk ditemukan penjelasan akademiknya dan dicarikan maknanya, seperti, mengapa anak-anak migran muslim banyak yang suka kepada pendidikan, guru-guru SD juga menempuh pendidikan tinggi dan hampir semua jadi sarjana Strata 1, etos apa yang meletarbelakangi keberhasilan guru-guru dan anak transmigrasi, mengapa anak transmigran suka mengejar pendidikan. Mengamati fenomena di atas menyebabkan penulis ingin tahu dan tertarik untuk memahami fenomena keberhasilan masyarakat migran muslim di bidang pendidikan, motivasi berprestasinya, dan kesejahteraannya.

Menurut asalnya, masyarakat di Pangkoh dibedakan menjadi dua, yaitu kelompok masyarakat lokal ash, baik dari suku Dayak maupun dari suku Banjar, dan kelompok masyarakat pendatang. Kelompok pendatang adalah warga transmigran atau migran yang menempati lokasi pemukiman tersendiri sejak tahun 1982, kemudian terjadi pembauran melalui perkawinan dengan penduduk lokal. Lokasi pemukiman yang dihuni masyarakat transmigran.

Keluarga transmigran di pemukiman Pangkoh 1 sampai 11 berjumlah 6.287 kepala keluarga (KK) menempati 5.866 rumah, dalam wilayah Kecamatan Pandih Batu terdapat 16 desa dengan jumlah penduduk 22.496 jiwa, laki-laki 11.736 dan perempuan 10.760 orang atau $19,73 \%$ dari 114.000 jiwa penduduk Kabupaten Pulang Pisau, $3^{\circ}$ dari sudut agama yang dipeluknya, masyarakat Pangkoh dapat dibedakan menjadi tiga (3) kelompok pemeluk agama, Muslim sebanyak 22.456 jiwa ; Kristen dan Katolik 15 jiwa; dan Hindu Kaharingan 21 jiwa.

Pengamatan awal mendapati transmigran muslim menjalani pekerjaan yang bervariasi, meskipun masih mengurus lahan pertanian sebagai pekerjaan pokok, transmigran menggunakan waktu luang untuk merintis usaha sampingan, seperti menjual sembilan bahan kebutuhan pokok, mengajar tidak tetap di Madrasah Diniyah dan PNS. Selain itu, tidak sedikit yang bekerja di bidang jasa ojek, pengemudi angkutan umum, servis alat elektronik, dan kerja sebagai tukang bangunan. Pendapatan kepala keluarga transmigran antara $\mathrm{Rp}$ 440.000 sampai dengan Rp. 1.600.000 perbulan, sementara itu, standar upah minimum pekerja provinsi adalah Rp. 1.000.000 perbulan.

Pendidikan

bermakna mengembangkan potensi peserta didik, anak-anak transmigran, guna meningkatkan kecerdasan, memperkuat kreativitas, dan menyiapkan out put yang terampil, meningkatkan kecerdasan, kreativitas, dan ketrampilan adalah melalui pendidikan. Tetapi individu di daerah transmigran masih dihadapkan pada permasalahan, yaitu antara lain rendahnya level pendidikan orangtua, lokasi pemukiman kurang subur, sedikitnya tenaga terampil dan jauh dari lembagalembaga pendidikan menengah atas, apalagi perguruan tinggi. Selain itu, mutu guru dan kualifikasi guru bidang studi masih dalam 
pembenahan, tak ada kemitraan yang terprogram antara lembaga pendidikan dengan sektor usaha.

Anak transmigran banyak mempunyai etos seperti remaja yang masih bersekolah di Madrasah Tsanawiyah sebanyak 192 orang, sebanyak 989 orang bersekolah di Sekolah Menengah Pertama (SMP), 189 siswa bersekolah di Madrasah Aliyah, 210 siswa di Sekolah Lanjutan Tingkat Atas, berkuliah di STAIN 95 orang, berkuliah di Universitas Palangka Raya 105 orang, di Perguruan tinggi Swasta 60 orang serta yang menjalani/menyelesaikan S2 sebanyak 5 orang.

Penelitian fenomena etos pendidikan dan kesejahteraan menjadi fokus penelitian karena memiliki karakteristik yang menarik yaitu banyak anak migran Muslim berhasil di bidang pendidikan pada dasawarsa ketiga (2002-2011), yang diduga karena etos mereka. Citra keluarga yang berhasil menyekolahkan anak dipandang masyarakat mempunyai martabat, mengangkat nama baik keluarga, keluarga yang berhasil meraih pendidikan sari ana terlihat makmur, menyekolahkan anak-anak, dan mampu menunaikan ibadah umrah atau hajji. Sehubungan dengan itu, peneliti termotivasi untuk meneliti dan memahami fenomena etos di balik semangat khas orang migran pada bidang pendidikan, dan kesejahteraan dari Islam dan perspektif psikologi.

Kunjungan dan pengamatan di lokasi melihat beberapa beberapa karakteristik dalam masyarakat migran seperti petani, berkarakteristik pedagang, karakteristik pengusaha, kareakteristik pegawai, karakteristik politisi, karakteristik pembina moral/karakter dari sebanyak kepala keluarga. Karakteristik dikenali, diamati berulang-kali dalam waktu yang relatif lama, sehingga dapat dikatakan sudah sampai kepada titik jenuh artinya di Pangkoh tidak ditemukan lagi karakteristik yang baru, dari karakteristik itu disederhanakan menjadi dua (2) kategori merujuk kepada pendidikan awal mereka.

Penelitian ini bertujuan mendeskripsikan dan memaknai fenomena etos menempuh pendidikan, keberhasilan dan kesej ahteraan migran muslim Pangkoh dengan menggunakan telaah Islam dan psikologi. Hasilnya berguna untuk mengembangkan etos pendidikan pada keluarga migran muslim, masukan pemerintah daerah Kabupaten Pulang Pisau, dan menunjukkan citra terkini, citra lama mengasumsikan bahwa orang migran muslim di Pangkoh berpendidikan rendah.

\section{KAJIAN LITERATUR}

\section{Penelitian yang Relevan}

a. Ahmad Janan Asifudin (2003).

Menurut Asifudin etos kerja islami adalah karakter dan kebiasaan manusia berkenaan dengan kerja, terpancar dari sistem keimanan/ aqidah Islam yang merupakan sikap hidup mendasar terhadapnya. Aqidah itu terbentuk oleh pemahaman yang diperoleh dari ajaran Wahyu dan akal yang bekerjasama secara proporsional. Maksud terpancar !di sini mencakup arti dan fungsi aqidah yang menjadi sumber motivasi serta sumber acuan dan nilai sehubungan dengan kerja.

Karakteristik etos kerja islami digali serta dirumuskan berdasarkan konsep iman dan amal saleh yang mensyaratkan ilmu, yaitu: (1) kerja merupakan penjabaran aqidah. (2) kerja dilandasi ilmu; dan (3) kerja dengan meneladani sifat-sifat Ilahi serta mengikuti petunjuk-pctunjuk-Nya. Dari tiga karakteristik etos kerja islami itu, ternyata dapat ditemukan hampir seluruh penampilan lahiriah ciri-ciri etos kerja tinggi pada merupakan agama amal, Selain itu, menunjukkan bahwa cara berpikir induktif dikembangkan pula dengan penelitian ini. Pada telaah psikologi terhadap latar belakang terbentuknya etos kerja islami digunakan telaah kritis terhadap bahanbahan literer yang relevan. Masing-masing 
diarahkan pada dihasilkannya kesimpulan yang menJawab seluruh pokok masalah yang ditargetkan. Bandingkan hasil penelitian Jirhanuddin 2001 pascasarjana UII Yogyakarta, yang meneliti Agama dan etos kerja pada masyarakat suku Dayak desa Lanjas, Muara Teweh, Kalimantan Tengah, bahwa pemahaman keagamaan tentang teologi kebebasan dan keterkaitan manusia, iman kepada hari akhir, takdir, pandangan tentang harta dan kehidupan dunia pada Suku Dayak masih bervariasi. Pada kelompok petani, PNS dan nelayan pemahaman keagamaan adalah baik dan positit sedangkan pada kelompok pedagang muslim dan tokoh agama cenderung memiliki pemahaman keagamaan yang negatif artinya pemahamannya kurang melahirkan etos kerja yang tinggi pada umumnya, seperti efektif, disiplin, profesional, tekun, dan hemat. Keunikan etos kerja islami yang berbeda dengan lainnya memang tidak pada penampilan lahir, tetapi pada sumber motivasi dan sumber nilai yang dimiliki.

Telaah terhadap penelitian di atas:

Asifudin meneliti etos kerja Islami menggunakan research kepustakaan, Teoriteori psikologi, khususnya psikologi motivasi digunakan menelaah motivasi kerja islami. Ia menemukan definisi etos kerja islami, karakteristiknya dan menerapkan telaah psikologi terhadap etos kerja yang dipaparkan secara jelas dan menarik. Sedangkan tema penelitian Etos Pendidikan dan Kesejahteraan Migran Muslim, dari pengusul adalah berbeda dengan apa yang dikeijakan Asifudin, inaka hasilnya dapat melengkapi.

Dalam upaya mendapatkan informasi hasil-hasil penelitian yang dilakukan lebih dahulu dan terkait dengan tema atau fokus penelitian tentang orang migran, maka telah melacak beberapa jurnal menggunakan mesin pencari "Google" hasil sebagai berikut:

\section{b. M. Gunthar Riady (2002)}

M Gunthar meneliti kemampuan adaptasi masyarakat transmigran di Unit Pemukiman Transmigrasi Kota Bangun, dengan sampel penelitian sebanyak 120 orang kepala Keluarga, Kalimantan Timur M.Gunthar Riady menemukan dua hal: (1)Tingkat kemampuan adaptasi transmigran adalah rendah. Hanya $21 \%$ dari responden yang mempunyai klasifikasi tinggi. Hal ini diperkuat pula oleh kenyataan bahwa tingkat pendapatan Keluarga transmigran pada umumnya rendah. Hanya 35\% dari mereka yang termasuk kategori tidak miskin dengan tingkat pendapatan > Rp 455.900,- perkapita per tahun. (2) Hasil perhitungan kuadrat Chi dan Koefisien Kontingensi dengan (\&\#61699;=0,05) maka dapat diketahui bahwa: (a) Tingkat kemampuan adaptasi transmigran di pengaruhi oleh tingkat pendidikan $(\mathrm{C}=0,35)$, artinya hubungan kedua variabel tersebut tergolong cukup kuat; (b) Tingkat kemampuan adaptasi transmigran dipengaruhi oleh tingkat teknologi yang dikuasainya $(\mathrm{C}=0,55)$, artinya tingkat keeratan hubungan itu kuat; (c) Tingkat kemampuan adaptasi transmigran dipengaruhi tingkat orientasi pasar $(\mathrm{C}=0,38)$, artinya tingkat keeratan hubungan itu termasuk cukup kuat; (d) Tingkat kemampuan adaptasi transmigran dipengaruhi tingkat kebutuhan hidupnya $(\mathrm{C}=0,28)$, artinya keeratan hubungan itu termasuk cukup kuat; (e) Tingkat kemampuan adaptasi transmigran dipengaruhi pekerjaan pokok di tempat asalnya $(\mathrm{C}=40)$, artinya tingkat keeratan hubungan itu termasuk kuat; (f) Tingkat kemampuan adaptasi transmigran dipengaruhi oleh motivasinya bertransmigrasi $(\mathrm{C}=0,42)$, artinya tingkat keeratan hubungan tersebut termasuk kuat.

\section{c. Yusak Maryunianta (2002)}

Yusak meneliti sifat mobilitas transmigran dan menganalisis faktor-faktor sosial ekonomi yang berpengaruh terhadap mobilitas transmigran untuk bekerja, dengan tema pengaruh beberapa faktor sosial ekonomi terhadap mobilitas transmigran 
Sikara-kara, Sumatera Utara. Yusak Maryunianta menemukan dua hal berikut: (1) mobilitas transmigran untuk bekerja pada masyarakat transmigran Sikara-kara bersifat non-permanen dalam bentuk sirkuler dan ulang alik. (2) variabel yang berpengaruh terhadap mobilitas transmigran adalah rendahnya produktifitas lahan, tingginya kebutuhan pokok dan non-pokok keluarga, dan tingkat pendidikan formal. Ketrampilan yang dimiliki transmigran menjadi faktor pendorong kerja, dan informasi kesempatan kerja di luar lokasi menjadi faktor penarik mereka bekerja.

\section{d. Penelitian tentang kesejahteraan migran pada daerah yang berbeda tahun 2006 oleh Tolnay, Stewart E; Eichenlaub, Suzanne C. (USA).}

Migrasi Besar ke selatan jauh dari tempat kelahiran merupakan salah satu peristiwa demografis yang paling signifikan dalam sejarah AS. Selama dan setelah Perang Dunia II, sebagian besar pindah ke Barat. Kami menggunakan informasi dari tahun 1970-2000 menggunakan sampel publik untuk membandingkan status ekonomi "migrant menetap" dari Timur Laut dan Midwest dengan "migran langsung" dari Selatan. Temuan kami menunjukkan bahwa migran menetap memiliki pendapatan yang lebih besar dan status pekerjaan yang lebih tinggi, tetapi tidak lebih mungkin untuk dipekerjakan daripada migran langsung dengan sosio-demografis profil yang sama. Keuntungan ekonomi yang dinikmati oleh migran menetap.

e. Penelitian tentang kesehatan mental migran perempuan Turki di Stockholm (2000) oleh Sofie Baarnhielm dan Solving Ekblad

Penelitian monyajikan hasil studi kualitatif yang bertujuan mengeksplorasi struktur inakna penyakit di kalangan somatizing Turki migran perempuan (usia 31 48 ) yang tinggal di pinggiran kota Stockholm dalam kondisi miskin dan minim kontak dengan pelayanan kesehatan lokal. Dua sampai tiga kali kunjungan wawancara tentang pengalaman dan pemahaman terhadap penyakit telah dilakukan serta memvalidasi hasil wawancara lanjutan pada tahun berikutmia.

Wawancara dianalisis dengan pendekatan grounded theory. Hasil disajikan sebagai pemahaman participants'agenda.

Kondisi tertekan dikomunikasikan melalui ekspresi konkret tubuh, emosi, sosial dan situasi kehidupan. Rasa nyeri kerap terjadi dan sering beralih dari satu ke satu sisi tubuh lain. Atribusi ditandai dengan ungkapan verbal yang koheren antara kesehatan dan aspek kehidupan.

Atribusi kejiwaan dinilai sebagai alat untuk pemulihan dari menekan emosi. Ditemukan dua sumber utama penyembuhan yaitu perawatan medis di Swedia dan Turki dan pengobatan tradisional.

Kapasitas mempengaruhi pemulihan yang paling terendah. Hubungan dengan keluarga dan dokter dianggap sebagai bagian penting pemulihan. Pertemuan dengan perawatan kesehatan setempat telah membawa peserta dalam kontak agenda psikologis untuk memahami penyakit mereka dan cara-cara baru berhubungan dengan penyembuhan penyakit. Mereka semua aktif berusaha, namun mengalami berbagai kcsuli tan. Hasil penelitian diperlukan saling mengeksplorasi dalam pertemuan klinis, dapat membantu pasien cepat sembuh dari penyakit.

\section{f. Penelitian tentang kesejahteraan migran (2008)}

Penelitian menunjukkan bahwa kesejahteraan migran adalah fenomena bertingkat, dinamis, dan bernilai. Bertingkat karena risiko dan faktor pelindung yang hadir pada ekologi, dari individu ke bidang sosial. Dinamis karena risiko obyektif dan subyektif dan faktor pelindung saling berinteraksi pada tingkat ekologi, menciptakan kondisi yang menguntungkan 
untuk menyesuaikan diri dengan lingkungan baru. Bernilai karena akses ke sumber daya dikondisikan oleh nouna-norma keadilan di masyarakat. Temuan ini merupakan akulturasi .yang digabungkan dengan literatur sebelumnya untuk mendukung tiga klaim yang diajukan dalam karya ini.

Telaah terhadap penelitian di atas: Dibandingkan dengan penelitian-penelitian terdahulu seperti disebutkan sebelumnya terhadap orang-orang yang berpindah (migran) dari daerahnya, penelitian disertasi ini memiliki ciri khas tersendiri. Pertama lingkungan alam di Pangkoh sangat berbeda dengan penelitian yang pernah dilakukan di luar negeri. Begitu suasana keagamaan dan norma-norma yang berlsembang. Misalnya imigran yang memiliki latar belakang katolik dan Luteran nampak rawan konflik tidak rukun maupun guyub. Munculnya Konflik besar dipengaruhi oleh adat kebiasaan minum whiskey atau minuman keras. Hal ini tidak terjadi pada transmigran Pangkoh, walaupun di sana ada beberapa keloinpok etnis dan terdapat tiga (3) pemeluk agama, akan tetapi mereka hidup rukun dan damai selama tiga dasawarsa di Pangkoh.

\section{Etos Pendidikan}

Etos pendidikan berasal dari dua kata yaitu etos dan pendidikan. Etos dapat berarti abode ${ }^{\circ}$ dwelling place. 41 Dalam bahasa Yunani, ethos berarti karakter dasar. Ethos bila dikaitkan dengan kebijaksanaan (wisdom) dapat berarti the recreation and re-affirmation of created order. Heidegger. mengaitkan keberadaan dengan tempat tinggal dan berpikir dengan esensi menjadi manusia. A man character is his spirit. Dengan kata lain, the inborn nature of man becomes his guiding spirit, his god.

Karlyn Kohrs Campbell, Susan Schultz Huxman mengartikan ethos sebagai suatu attitude atau sikap - the impressions or images people have of the source of a message. Like all attitudes, those about the credibility of a rhetor.
Dengan demikian etos pendidikan dapat dikatakan sebagai semangat fundamental, karakter, perilaku, sikap, kebiasaan dan spirit, menaruh kepercayaan (trust) dan mcnyikapi secara positif dan penuh harapan kepada pendidikan, bersumber dari motif internal atau motif eksternal, sehingga pendidikan menjadi harapan. Sumber motif internal dan eksternal selain dari psikologi, juga dari ajaran Agama yang dipeluk dan aspek budaya etnisitas.

Beberapa contoh penggunaan istilah etos pendidikan: He envisions an explicitly pluralist educational ethos emerging as a shift is made away from delivering curricular commodities toward revitalizing commitment-to andcapacities -for educational craft:

(Dia menyatakan bahwa etos pendidikan pluralis eksplisit muncul sebagai pergeseran kurikuler menuju revitalisasi komitmen terhadap kapasitas untuk pendidikan khusus kerajinan) Contoh penggunaan kata etos pendidikan, Good menyatakan bahwa.. debate over what would constitute the school's educational ethos, its essential "cultural" image, colored the early years of innovation... (...perdebatan mengenai etos pendidikan, sekolah dan pentingnya citra "budaya", menjadi inovasi yang ramai pada awal tahun ...). In this context of exclusive educational ethos that we have to project the development of special education.

(Dalam konteks etos pendidikan, digunakan untuk pengembangan pendidikan tertentu).

Toncich menyatakan sebagai berikut:

there is no more concise description of the purpose of universities and their educational ethos. ...The educational ethos of universities, as simply encapsulated by 'ancora imparo' is one into which secondary school students must to grow to fully appreciate.

Louie: this educational ethos extended even tothe peasants, the group least likely to benefit from the examination system. (etos pendidikan mempengaruhi 
secara luas termasuk kelompok yang tidak terlalu mendapat manfaat dari sistem ujian).

The third model of comprehensive education, the egalitarian, which although not opposed to either academic excellence or improved social relationships, stresses the importance of changes in educational ethos and the structurre of the learning process. Haydon: the notion of ethos seems to be the one most directly associated with values. This is partly because ethos emerges as being the most concerned with subjective factors that seem to be imprtant to the life of a school but are hard to characterise objectively or to measure...

Dengan kata lain nilai-nilai dapat juga meningkat karena etos yang digunakan di sekolah ketika mereka membicarakan nilai-nilai.

Observasi awal di lokasi, masyarakat migran memiliki etos pendidikan yang langsung dan tidak langsung, terlihat ada etos yang dimiliki kelompok selain yang perorangan. Keluarga transmigran adalah sebuah satuan kecil dalam masyarakat transmigran, terdiri dari sekurangnya suami, istri, dan anak yang semuanya muslim. Transmigrasi adalah perpindahan penduduk secara sukarela untuk tujuan meningkatkan kesejahteraan di wilayah (baca: desa) atau lokasi eks unit pemukiman transmigrasi (UPT).56 Penggunaan istilah transmigran dan kata migran sengaja tidak dibedakan, maka dipakai secara bergantian. Jadi istilah transmigran dalam penelitian ini adalah warga negara Republik Indonesia yang berpindah dari pulau Jawa ke lokasi pemukiman melalui pengaturan pemerintah atau perpindahan alas kemauan sendiri yang mendapat ijin dari pemerintah setempat. Dengan kata lain, sosok individu ayah, ibu, dan keturunannya yang

memiliki etos yang kait dengan faktor internal dan eksternal, dituangkan menjadi kerangka pikir penelitian pada gambar berikut:

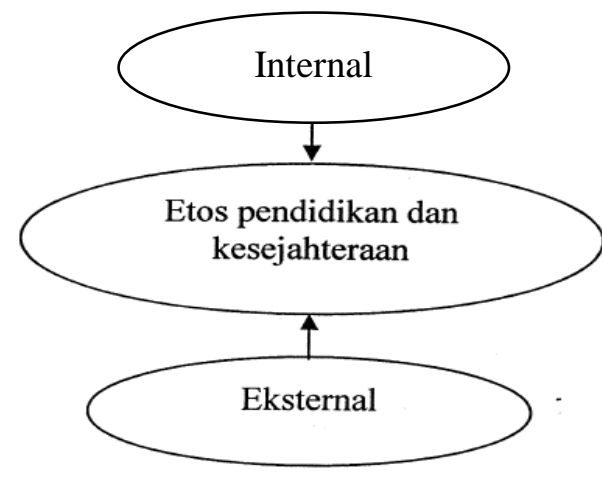

Gambar 1.1 Kerangka Berpikir

\section{Kesejahteraan}

Dalam ilmu sosial, humaniora dan psikologi, kesejahteraan sering dibagi dua. Kesejahteraan objektif atau sering disebut indikator sosial, dan kesehjateraan subjektif yang saat ini sedang hangat dibicarakan para ilmuwan sosial. Karena kesejahteraan subjektif dalam berbagai penelitian dirasakan lebih penting dari kesejahteraan objektif yang merupakan kesejahteraan yang dipatok oleh negara atau institusi tertentu.

Seligman (1998) berpendapat, seseorang dengan harta yang melimpah dan dari segi materi tercukupi, tidak dapat dikatakan memiliki kualitas hidup yang baik, apabila hidupnya dipenuhi dengan keluhan, depresi, dan gangguan mental.

Saat ini psikologi positif memiliki pusat studi emosi (Emotion centre)7yang erat kaitannya dengan kesejahteraan subjektif. Berbagai bentuk emosi positif diteliti guna meningkatkan kesejahteraan subjektif individu. Salah satu studi yang dilakukan adalah membangun emosi moral positif. Studi terhadap kesejahteraan subjektif juga merupakan studi kesehatan mental dan fisik yang penting. Diener dan Myers, dan sejumlah psikolog sosial menyebut kesejahteraan subjektif sebagai "ilmu pengetahuan tentang kebahagiaan" (science of happiness).

Mereka menyatakan bahwa kesejahteraan subjektif adalah evaluasi manusia secara kognitif dan afektif terhadap 
kehidupan mereka. Dua bentuk evaluasi ini menjadi komponen kesejahteraan subjektif. Komponen kognitif sering disebut dengan kepuasan hidup dan komponen afektif sering disebut dengan afek. Beberpa penelitian menunjukkan bahwa afek berperan terhadap kepuasan. Misalnya dalam suasana yang cerah individu cenderung memiliki skor yang tinggi dalam kepuasan hidup. $8^{\circ}$ Penelitian kesejahteraan subjektif yang terbanyak pada dasawarsa terakhir ini mencakup dua komponen tersebut. Beberapa penelitian di seluruh dunia menunjukkan manusia memerlukan pertolongan untuk menemukan apa yang membuat mereka bahagia.

Para psikolog sebenarnya dapat membantu menemukan jawaban faktorfaktor apa menyebabkan orang sejahtera dan bagaimana meningkatkannya.82 Sebelum itu, pertanyaan tentang kebahagiaan hampir tidak pernah ditanyakan oleh para psikolog abad pertama. Para psikolog lebih banyak menfokuskan pada aspek negatif dari kehidupan manusia. Perhatian para psikolog terhadap penyakit lebih besar daripada kesehatan, rasa takut lebih besar daripada keberanian, dan perilaku agresi lebih besar daripada rasa cinta.83 Penelusuran elektronik pada abstrak psikologi sejak tahun 1887 hingga tahun 1997 ditemukan artikel-artikel negatif dan positif dalam posisi tidak seimbang. Misalnya terdapat 8.072 artikel kemarahan, 57.800 artikel kecemasan, dan 70.856 artikel depresi; dan hanya 851 tentang kegembiraan, 2.958 kesejahteraan subjektif, dan 5.701 tentang kepuasan hidup. Perbandingan penelitian tentang emosi negatif dan positif adalah 17 ; 1.84 Hal serupa teijadi pada penulisan buku. Kebahagiaan dalam arti kesejahteraan subjektif saat sebelum psikologi positif dicanangkan masih sedikit diteliti dan dibicarakan. Individu yang memiliki kesejahteraan subjektif tinggi, ternyata merasa bahagia dan senang dengan teman dekat dan keluarga. Individu tersebut juga kreatif, optimis, kerja keras, tidak mudah putus asa, dan tersenyum lebih banyak daripada individu yang menyebut dirinya tidak bahagia. Individu yang bahagia (memiliki kesejahteraan subjektif yang tinggi) cenderung untuk tidak memikirkan diri sendiri, tidak memiliki banyak musuh, akrab dengan individu lain, dan lebih suka menolong. Keadaan jasmani individu yang bahagia lebih sehat, cepat sembuh dari penyakit dan lebih tahan menghadapi penyakit dibandingkan individu yang tidak bahagia. Individu yang bahagia cenderung melihat sisi "cerah" terhadap kehidupan. Melihat kepada individu yang lebih rendah dalam urusan materi. Perhatian terhadap individu yang lebih rendah dalam urusan materi, membuat individu merasa bersyukur karena merasa memiliki kelebihan dari individu lain. Apabila individu tersebut memberikan reaksi positif, misalnya dengan memberikan kelebihan yang dimiliki, maka akan meningkatkan emosi positif yang lain.

Berbagai hasil penelitian menunjukkan bahwa penggunaan alat ukur yang berbeda-beda nampaknya menghasilkan temuan yang konsisten. Berdasarkan uraian tersebut dapat diketahui, bahwa kesejahteraan subjektif memang diperlukan oleh individu dan nampaknya sangat berkaitan dengan nilai-nilai hidup yang dimiliki individu. Berdasarkan penelitian yang ada dapat disimpulkan bahwa kesej ahteraan subjektif dapat ditingkatkan. Misalnya dengan menumbuhkan nilai-nilai moral seperti pemaaf, bersyukur, berperilaku gembira, aktif menolong individu yang membutuhkan, dan memelihara rohani. Nilai-nilai moral ini juga menjadi perhatian para peneliti psikologi positif.

Sementara perhatian masyarakat terhadap masalah kesejahteraan subjektif semakin bertambah, namun banyak penelitian empiris terhadap usaha-usaha untuk meningkatkan kesejahteraan subjektif dengan melalui peningkatan aspek fisik (indikator objektif)kurang memperlihatkan hasil yang memuaskan. Penelitian-penelitian 
terhadap variabel-variabel eksternal, seperti penghasilan, kesehatan, dan jenjang pendidikan menunjukkan hal itu. Para peneliti seperti Oishi et al. (1999) dan Suh et al. (1998) kemudian mengalihkan perhatian mereka pada sebab internal. Seperti nilainilai hidup individu dan kepribadian. Penelitian mereka mendapat dukungan dari para ahli psikologi kesejahteraan subjektif. Berbagai penelitian menunjukkan bahwa nilai-nilai yang terkandung dalam ajaran berbagai agama merupakan hal yang cukup penting dalam mengatasi berbagai masalah psikologi dan mampu meningkatkan kesejahteraan individu. Misalnya penelitian yang pernah dilakukan terhadap mahasiswa yang mengambil mata kuliah psikologi kesehatan. Mahasiswa yang diberi perlakuan untuk menghitung nikmat ternyata memiliki afek positif dan kepuasan hidup yang lebih baik daripada yang tidak.

Nilai ajaran agama, misalnya etos yang tinggi dalam beribadah antara lain bekerja dengan cara membangun emosi positif dan meningkatkan motivasi individu. Pernyataan ini dikuatkan dengan berbagai temuan empirisml. Nenek moyang bangsa Amerika khususnya dan bangsa-bangsa lain dahulu memiliki perabot spiritual untuk duduk dengan nyaman tatkala mereka mengalami kegagalan. Perabot tersebut adalah kedekatan dengan Tuhan.

Perhatian yang semakin meningkat terhadap nilai-nilai agama yang universal, bukanlah tanpa alasan sama sekali. Secara umum dalam berbagai penelitian agama membawa kehidupan yang lebih baik bagi pemeluknya. Studi meta-analisis yang dilakukan terhadap berbagai hasil penelitian dengan subyek yang cukup banyak secara statistik, menguatkan pendapat tersebut. $1^{\circ} 4$ Para pemeluk agama yang aktif menjalankan ibadahnya, mempunyai umur yang lebih panjang daripada yang tidak.

Teori top down mencakup beberapa teori yang menjelaskan proses munculnya rasa bahagia dari dalam diri individu. Teori bottom up menjelaskan faktor-faktor eksternal yang menyebabkan individu merasa sejahtera. Teori top-down menjelaskan faktor-faktor internal yang menyebabkan individu sejahtera. Misalnya faktor kepribadian, tujuan, nilai, dan kepercayaan.

Aktivitas keagamaan yang sering dihubungkan dengan kebahagiaan adalah aktivitas sosial yang dilakukan individu yang beragama. Misalnya menolong orang yang berada dalam kesulitan dan melontarkan senyuman terhadap orang lain. Menurut teori Facial feedback hypothesis yang merupakan penjelas dari teori top down, individu yang berusaha tersenyum terhadap orang lain akan menimbulkan rasa sejahtera. Begitu pula dengan memberikan pertolongan terhadap orang lain akan menimbulkan emosi positif misalnya delasi (delation) yang berhubungan erat dengan kebahagiaan individu.

Mengacu pada kemampuan teoriteori di atas untuk menjelaskan hubungan antara ajaran agama dan kesejahteraan subjektif dan hasil penelitian yang ada $1^{\circ} 7$ maka merupakan suatu hal yang rasional untuk melakukan penelitian hubungan nilainilai agama dan kesejahteraan subjektif atas dasar teori-teori ini. Mereka menganggap Islam perlu diteliti untuk melihat sejauh mana perannya terhadap kesejahteraan subjektif dan untuk melihat apakah agama secara umum berperan positif terhadap kesejahteraan subjektif. Penelitian tentang masyarakat Islam dan Kesejahteraan subjektif memang sesuatu yang baru. Bahkan dua dasawarsa terdahulu belum ditemukan penelitian tersebut. Para ahli psikologi yang bergabung dalam psikologi positif, seperti Emmons dan Paloutzian (2003); Seligman (1999), McCullough et al, (2004) umumnya berpendapat bahwa ajaran Islam mengandung nilai-nilai yang secara empiris mampu meningkatkan kesejahteraan subjektif. Seperti rasa syukur, dan perilaku 
syukur, perintah untuk memaafkan orang yang menganiaya, dan silaturrohim.

Penelitian tentang kesejahteraan subjektif dalam jurnal-jurnal yang terbit kemudian tidak selalu konsisten dengan istilah kesejahteraan subjektif. Istilah bahagia (happy) dan kebahagiaan (happiness) masih sering dipakai dalam banyak penelitian. Dalam psikologi positif kesejahteraan subjektif menjadi salah satu pusat perhatian, karena kesejahteraan merupakan aspek positif individu. Kesejahteraan subjektif dapat didefinisikan sebagai evaluasi kognitif dan afektif terhadap kehidupan. Evaluasi kognitif orang yang bahagia berupa kepuasan hidup yang tinggi, evaluasi afektifnya adalah banyaknya afek positif dan sedikitnya afek negatif yang dirasakan.

Pembahasan tentang teori selama 30 tahun terakhir ini telah mengalami pergeseran penekanan. Penekanan penelitian mula-mula tertuju pada postulat yang menyatakan bahwa agar orang dapat hidup bahagia kebutuhan-kebutuhan tertentu hams dipenuhi (pandangan hedonik). Penekanan terakhir tertuju pada postulat yang menyatakan bahwa ada faktor-faktor tertentu dalam diri manusia yang membuat individu bahagia (pandangan eudaimonik). Pendekatan pertama berusaha Mengidentifikasi faktor-faktor eksternal, situasional, atau bottom-up. Pendekatan kedua menfokuskan pada proses top-down, yaitu faktor-faktor dalam diri manusia seperti nilai-nilai hidup, dan kepribadian. Teori-teori kebahagiaan kemudian dibangun dari kedua proses tersebut, yaitu teori bottom-up dan teori top-down.

\section{a. Teori bottom-up.}

Diener (1984) membedakan antara proses topdown dan bottom-up yang mempengaruhi kesejahteraan subjektif. Faktor-faktor bottom-up yang mempengaruhi kesejahteraan subjektif adalah peristiwa-peristiwa luar, situasi, dan pengaruh demografis. Pendekatan bottom-up dibangun atas ide Wilson bahwa ada kebutuhan-kebutuhan manusia yang bersifat mendasar dan umum, bila kebutuhankebutuhan tersebut terpenuhi,' maka dia akan berbahagia "2(Diener, 2000). Menurut Diener dan Scollon (2003) kebutuhan dasar individu bervariasi tergantung budaya, nilai hidup, dan kepercayaan.

Menurut teori bottom-yq, kesejahteraan subjektif hanya sebagai akumulasi kegembiraan yang kecil-kecil. Pendekatan ini menjelaskan, bahwa tatkala seseorang menilai apakah kehidupannya bahagia atau tidak, beberapa kalkulasi mental digunakan untuk menjumlah kegembiraan-kegembiraan dan penderitaanpenderitaan yang pernah dialami. Bermacam-macam penelitian dengan pendekatan bottom-up telah dilakukan. Faktor-faktor luar yang pernah diteliti adalah penghasilan dan kekayaan, kesehatan, prestasi belajar (Crocker et al., 2003), dan penampilan fisik. Hasil-hasil yang ditunjukkan dalam penelitian tersebut adalah bahwa faktor-faktor eksternal dapat meningkatkan kesejahteraan subjektif walaupun dalam jumlah sedikit.

b. Teori top-down.

Para peneliti sering kecewa terhadap pengaruh yang relatif kecil dari variabelvariabel eksternal. Karena efeknya yang kecil maka para peneliti berpaling pada daerah top-down.

Pada beberapa dekade terakhir, peneliti mulai beralih mengeksplorasi daerah dalam diri manusia. Misalnya nilai-nilai hidup, tujuan dan kepribadian individu. Ahli Psikologi menyebut pendekatan ini dengan teori top-down, yaitu seseorang menikmati kesenangan sebab dia bahagia, bukan sebaliknya. Struktur dalam diri manusia seperti nilai hidup, faktor genetik, temperamen dan kepribadian menyeluruh dianggap mempengaruhi cara orang bereaksi terhadap suatu peristiwa. Sebagai contoh, individu yang optimis, riang mungkin akan 
menafsirkan sejumlah besar peristiwa sebagai sesuatu yang positif.

Berdasarkan uraian yang telah diutarakan sebelumnya, maka dapat di simpulkan bahwa teori-teori kesej ahteraan subj ektif .dapat menjelaskan mengapa orang merasa bahagia dan dapat digunakan bagaimana menumbuhkan kebahagiaan atau meningkatkan kesejahteraan subjektif. Teori tertentu sering memperjelas teori yang lain.

Komponen kehidupan yang kait dengan kesej ahteraan subj ektifPenelitianpenelitian tentang Faktor yang mempengaruhi kesejahteraan subjektif dapatdikelompokkan menjadi dua: faktor eksternal dan internal. Penghasilan, kesehatan, bentuk tubuh, dan faktor demografis (usia, jenis kelamin dan pendidikan) merupakan faktor eksternal. Temperamen, nilai-nilai hidup yang ada pada diri manusia dan kepribadian merupakan faktor internal Selain itu, yang turut mempengaruhi adalah (1) Penghasilan, (2) Usia, (3)Tingkat pendidikan, (4) Budaya, dan (5) Agama.

\section{MASYARAKAT MIGRAN MUSLIM PANGKOH}

Nama permukiman Pangkoh dimulai dari pembentukan sebuah Unit Pemukiman Transmigran (UPT) Pangkoh yang dipimpin oleh Soepardi (60 tahun) seorang kepala UPT. Jabatan kepala UPT ditetapkan oleh Kepala Kantor Wilayah Transmigrasi Provinsi Kalimantan Tengah. Kepala berkantor di lokasi pemukiman. Kepala memanage 11 unit pemukiman, yang secara keseluruhan dikenal warga dan pemerintah kabupaten sebagai pemukiman Pangkoh Iblok A, I-B, I-C. Pangkoh II-blok A,B,C, dan Pangkoh III-blok A, B, C. Kantor kepala UPT terletak di Pangkoh III-B.

Lima tahun kemudian warga tarnsmigran mengajukan usul kepada 117 Sesudah otonomi Daerah Kalimantan Tengah, nama instansi dimaksud menjadi Dinas Tenaga Kerja, Kependudukan dan
Transmigrasi Provinsi Kalimantan Tengah. Lihat dokumen Surat Keputusan Gubernur Kalimantan Tengah Nomor:20 tahun 2004 Pemerintah Daerah untuk mendapatkan status desa yang definitif Status pemukiman meningkat sejak terbitnya surat keputusan bupati, sehingga menjadi desa-desa pemukiman transmigrasi yang berjumlah 11 dan menjadi wilayah Kecamatan Pandih Batu. Meskipun menjadi desa-desa yang definitif, akan tetapi penyebutan nama yang selalu dipakai oleh masyarakat Pangkoh maupun masyarakat dari kabupaten lain dan instansi dinas atau swasta tetap menyebutnya Pangkoh sekaligus melengkapi nama blok, seperti Pangkoh III-blok B, dan seterusnya secara turun temurun tanpa menyebut nama desa lain, pada SK Bupati, ditetapkan dengan sebutan Desa Pangkoh Blok tertentu.

Lokasi pemukiman dirancatig oleh Kanwil, sekarang Dinas Transmigrasi pada tahun 197,1 di mana dengan jelas digunakan pada terminal atau pelabuhan untuk jalur transportasi tujuan, tempat ibadah, pasar, lokasi sekolah, lokasi pemukiman penduduk, tempat olah raga dan rancangan jalan darat. Sedangkan awal pembangunan sarana transportasi penduduk dirancang hukan melalui jalan darat, akan tetapi menggunakan jalur air sungai besar.

Sedangkan persiapan jalan darat, dirintis pada tahun 2000-2003 baru berupa badan jalan belum difungsikan karena tidak ada jembatan yang menghubungkan badan jalan yang telah ada.

Dari sisi agama yang dipeluknya, transmigran lokal adalah $2 \mathrm{KK}$ memeluk agama Nasrani dan 5 KK memeluk Hindu Kaharingan.121 Setelah menjadi desa definitif pemukiman Pangkoh berkembang menjadi desa-desa, yang berjumlah 16 desa dengan jumlah penduduk 22.496 jiwa, lakilaki 11.736 dan perempuan 10.760 pada Agustus 2011 atau $6.287 \mathrm{KK}$ dengan jumlah rumah warga 5.866.122 
Di antara warga transmigran asal suku Jawa dan transmigran lokal yang suku Dayak, telah terjadi perkawinan, menjalani kehidupan berumah tangga dan menghasilkan keturun, beberapa diantara masyarakat transmigran lokal perempuan menjadi muslim karena ketertarikanya untuk membangun rumah tangga secara Islam.

\section{Etos Pendidikan dan Kesejahteraan Migran Muslim di Pangkoh}

Berikut ini diutarakan etos pendidikan pada keluarga migran muslim pelabuhan Tanjung Perak Surabaya, dan sebagian lain diberangkatkan dari pelabuhan Tanjung Priok. Meraka diangkut menggunakan perahu-perahu ukuran terbuat dari kayu ukuran 2 x 20 meter menelusuri kanal atau sungai-sungai buatan pemerintah yang menuju masuk ke sekitar pemukiman yang baru disiapkan pemerintah di Pangkoh. Ketika menggali informasi, penulis membuat dua kategori informan. Kategori ini didasari pertimbangan latar belakang pendidikan informan pada awal kedatangan di lokasi migran yaitu pertama, kepala keluarga yang berpendidikan menengah sampai sarjana; kategori kedua, kepala keluarga yang hanya memiliki pendidikan dasar (9 tahun), sekolah dasar atau yang sederajat

\section{METODE PENELITIAN}

\section{a. Lokasi Penelitian}

Penelitian ini dilakukan di pemukiman transmigran Pangkoh dalam waktu yang cukup lama sekitar tiga tahun meskipun tidak secara terus-menerus. Pangkoh Kecamatan Pandih Batu Kabupaten Pulang Pisau Provinsi Kalimantan Tengah. Penelitian difokuskan pada etos pendidikan dan kesejahteraan masyarakat muslim pindahan (migran) dari Jawa, dengan komunitasnya yang homogen. Karena penelitian ini bersifat deskriptif kualitatif, maka sampel yang diamati atau diwawancarai tidak ditetapkan secara presential untuk mewakili populasi, tetapi lebih menitikberatkan kepada terhimpunnya data sesuai obyek dari sumbernya yaitu komunitas orang pindahan yang berasal dari pulau Jawa.

\section{b. Jenis Penelitian}

Penelitian ini adalah penelitian lapangan yang bersifat deskriptif kualitatif yang erat kaitannya dengan penelitian budaya, yaitu penelitian dengan menggunakan emik dalam anti bahwa peneliti mengumpulkan data yang berupa cerita-cerita dari para informan dan diungkapkan apa adanya sesuai dengan hahasa dan pandangan para informan. Dari ungkapan konsep ini, jelas bahwa yang dikehendaki adalah suatu informasi yang bersifat deskripsi seperti yang telah disebutkan sebelumnya.

Penelitian mengenai etos pendidikan dan kesejahteraan ini dapat dikategorikan kepada penelitian etnografi. Etnografi adalah penelitian untuk mendeskripsikan kebudayaan - termasuk perilaku dan sikap, dan cara berpikir- sebagaimana adanya. Penelitian ini berupaya mempelajari peristiwa kultural yang menyajikan pandangan hidup subjek sebagai obyek studi. Studi ini akan terkait bagaimana subjek berpikir, hidup dan berperilaku. Tentu saja perlu dipilih peristiwa yang unik yang jarang teramati oleh kebanyakan orang.

Selain itu, tentang etos migrant muslim dekat dengan penelitian budaya dan agama model kedua, seperti yang dijelaskan oleh Mattulada. Pertama, merujuk kepada fenomena dalam masyarakat, yakni titik tekannya pada aspek sosio kulturalnya. Kedua, berusaha memahami tingkah laku manusia dalam masyarakat yang dimotivasi oleh keyakinan keagamaan, yaitu melalui penangkapan fakta untuk mengungkap latar belakang yang terdalam dari individu yakni sejauhmana nilai tersebut menjadi milik pribadinya. Nilai sebagai sesuatu yang terdalam atau sebagai suatu sistem kepercayaan terefleksi pada perilaku 
seseorang dalam arti yang luas. Demikian sebaliknya seseorang yang di dalam dirinya bersemi nilai-nilai keagamaan akan terefleksi pula dalam kehidupannya.

Etos pendidikan dan kesejahteraan pada masyarakat migran muslim didekati untuk memperoleh deskripsi etos yang tumbuh dalam individu dan kelompok migran yang berpendidikan menengah. Demikian halnya mendekati etos yang tumbuh dari aspek internal dan aspek eksternal kelompok migran muslim yang berpendidikan dasar pada awal tiba di Pangkoh, selanjutnya dibuat sistematisasi dan diberi pemaknaan reflektif, bolak-balik antara makna pendidikan dan psikologi serta makna agama.

\section{c. Pengumpulan Data}

Teknik pertama yang digunakan dalam penelitian ini adalah wawancara mendalam teknik observasi dan life history (riwayat hidup migran yang ada hubungannya). Di samping itu, dilakukan pula pengamatan terlibat sebagai

Adapun subjek penelitian ini, terdiri dari dua kategori pendidikan awal subjek tiba di Pangkoh, yaitu yang berlatar belakang pendidikan menengah atau tinggi sebagai kategori pertama, dan keluarga migrant muslim yang pada awalnya hanya berpendidikan dasar sebagai kategori dua.

Pengelompokan seperti ini bagi penyusun, dimaksudkan untuk mengetahui perbedaan awal latarbelakang pendidikan masyarakat migrant muslim, mengetahui etos yang mula-mula tumbuh pada keluarga migran, dan etos anak-anak migran pada dasawarsa pertama, kedua, dan ketiga di Pangkoh. Etos pendidikan pada keluarga migrant muslim dapat diamati dengan melihat latar belakang pendidikan yang berbeda sebagai representatif dari beberapa keluarga migrant muslim karena keluarga migrant muslim adalah termasuk masyarakat yang relatif homogen.

\section{d. Analisis Data}

Pada prinsipnya analisis data dilakukan bersamaan dengan pengumpulan data di lapangan. Informasi dan data yang berhasil dikumpulkan di lapangan dianalisis melalui analisis secara kualitatif yaitu dengan cara melakukan deskripsi secara naratif dan interpretatif terhadap fenomena etos pendidikan dan kesejahteraan pada masyarakat migran muslim. Dalam memaparkan informasi dari lapangan perlu kode dan tema yang disarikan dari data. Miles dan Hubberman menyatakan, kode adalah peralata yang mengorganisasikan ke dalam permasalahan atau tema. Kode membuat data menjadi mudah dimengerti, mengarahkan jalinan huburigan, dan mempermudah untuk menghubungkan bagian-bagian yang berbeda menjadi bermakna Sudut pandang psikologi, akan dicoba untuk menyoroti fenomena etos pendidikan dalam individu dan keluarga transmigran. Data lapangan akan dianalisis secara bersama dengan proses pengumpulan data, dengan demikian, analisis sejak di lapangan penelitian.

Cara Memasuki Permukiman Pangkoh Melalui Jalan Darat Pada minggu pagi tanggal 14 Juni 2008, bertiga menuju pemukiman warga transmigran diantara seorang informan Tura (22 tahun) didampingi seorang mekanik sebagai pengemudi sepeda motor yang dalam kesehariannya kerja di sebuah bengkel Jakarta motor. Mekanik bernama Ahmad Dahlan, 20 tahun. Penulis dan dua orang itu berangkat dari jl. G.Obos pukul $06.00 \mathrm{~W} 113$ menuju lokasi pemukiman transmigrasi yang menjadi pedesaan. Pemukiman itu di sebutnya Pangkoh. Pemukiman Pangkoh ini seluas 1000 hektar, sebutan Pangkoh dibedakan menjadi Pangkoh 1, 2 dan 3. Masing-masing sebutan Pangkoh terdiri dari Blok Pemukiman. Blok pemukiman 
Pangkoh 1 terdiri dari Blok A, B, dan C. Dengan demikian Pangkoh terdiri dari 9 Blok pemukiman. Masing-masing Blok dari 9 itu dipimpin oleh kepala Blok yang disebut kepala dusun. Semua atau 9 Blok itu termasuk wilayah kecamatan Pandih Batu kabupaten barn hasil pemekaran daerah bemama Kabupaten Pulang Pisau.

Perjalanan bersepeda motor sejauh 310 km (PP) dari kota Palangka Raya. Jalan yang ditempuh, terdiri dari $50 \mathrm{~km}$ beraspal mulus, 105 kilometer jalan dalam proses pengerasan dan 30 kilometer jalan berlubang-lubang lebar dan dalam, serta becek karena terendam air dari sungai yang pasang dari sebelah kanan jalan. Karena kondisi jalan yang demikian kasar, penulis menjalaninya dengan perlahan, selain itu banyak kendala karena belum ada satupun jembatan yang dapat dilalui kendaraan roda dua. Tiap kendaraan melewati jembatan darurat yang terbuat dari kayu-kayu galam bulat yang ditata melintangi di atas ruas jalan dengan posisi disebelah kanan pekerjaan jembatan yang rusak parah atau akan mulai diperbaiki.

Dengan demikian, pengendara perlu menurunkan boncengannya, yang demikian dilakukan sebanyak lokasi jembatan yang secara bersamaan dalam perbaikan, berjumlah (21 buah) dalam perjalanan, penulis berhenti untuk mendinginkan mesin kendaraan setiap $75 \mathrm{~km}$, selain butuh istirahat dan minum kopi untuk mengurangi rasa kantuk.

Di sebuah desa transmigran yang bernama Kanamit, Tura mengajak singgah ke rumah orangtuanya, pak Parlan. Perjalanan menelusuri jalan yang pas-pasan dilewati roda sepeda motor selama 1 jam, menembus sela-sela pohon karet milik penduduk trans, hari mulai hujan rintikrintik yang membuat hati penulis cemas dan menahan-nahan rasa lelah dan haus, baru melihat ada beberapa rumah kayu panggung di tengah lahan.

\section{HASIL PENELITIAN DAN PEMBAHASAN}

Etos Pendidikan Pada Keluarga

Migran Berpendidikan Menengah di Pangkoh. Fenomena etos pendidikan pada keluarga atau masyarakat migran muslim yang berpendidikan menengah sampai sarjana menjalani kehidupan sebagai pendidik sekitar tiga (3) dasawarsa (19822011) yang diilustrasikan sebagai berikut:

Kondisi keluarga migran di Pangkoh pada dasawarsa pertama (1982 $\neg 1991)$ dalam kehidupan yang lebih banyah susah, meskipun ada sedikit kemudahan. Kemudahan memenuhi kebutuhan dasar seperti sandang, pangan, dan papan atau tempat tinggal tetap diakui, karena kebutuhan sandang dan pangan disediakan pemerintah selama dua (2) tahun pertama dengan istilah jatah hidup, atau semacam living cost pada tingkatan tertentu. Kondisi susahnya diakui lebih banyak daripada kemudahannya, seperti susah pendidikan, komunikasi, pekerjaan yang dirasa sangat berbeda dari kerja di daerah asal, silaturakhim, bertemu famili dan tetangga di daerah asal, dan susah mendapatkan hiburan, terutama kerinduan melihat pasar, memerlukan transaksi jual-beli. Kondisi ini diakui dan dirasakan yang ikut menjadi semacam uji ketabahan, gambaran mengenai kondisi awal di lokasi transmigrasi, diceritakan oleh Duro 52 tahun sebagai berikut:

Pada awal tiba di lokasi ya bimbang karena belum menguasai lingkungan sekitar pemukiman, lokasi kantor kecamatan terdekat (Pulang Pisau) ketika itu terasa sangat jauh, hanya ada jalur transportasi kapal yang lewat sekali dalam tiga (3) hari, itupun memerlukan waktu 12 jam satukali jalan. Bertahan di sana menunggu kapal untuk kembali sekitar tiga (3) hari, baru bisa pulang. Kondisi demikian memposisikan kantor unit pemukiman transmigrasi (UPT) Pangkoh menjadi pusat informasi dan seperti pentingnya kantor kepala desa dan kantor Kecamatan di Pangkoh. Pengakuan Duro 
relevan dengan apa yang diakui Ghofir, 55 tahun tetapi Ghofir mengaitkan dengan pendidikan, katanya:

Keinginan meningkatkan pendidikan lanjut pada guru-guru baru CPNS ada, tetapi dalam impian karena hams bekerja mendidik dan mencerdaskan anakanak transmigran di lokasi yang sangat banyak tetapi banyak juga kendala menuju sekolah, dan sarana belajar yang bersahaja, seperti dikatakan oleh Duro yang lulusan SPG mendapat pengangkatan PNS untuk SD di lokasi pemukiman transmigrasi Pangkoh.

a. Pendidikan pada diri dan keluarga meningkat

Selain pengakuan dua orang guru di atas, Suban, 56 tahun seorang lulusan SPG pada awalnya, sekarang menjadi sarjana S.1 Ilmu Pemerintahan dari Universitas Tebuka, juga meng-iyakan informasi yang disampaikan oleh Duro dan Ghofir, tetapi Suban menambahkan impiannya yang berkaitan dengan masa depan orang tua dan anak yang muslim, dengan mengatakan bahwa:

Pokoknya putra-putri harus menjalani pendidikan sekolah Islam yang padu dengan umum, memiliki motif tertentu yang relevan dengan Islam; (1) anak jangan sampai menjadi pemeluk agama lain, karena pihak nenek dan kakek dari ibu (istriku) adalah Pendeta aktif di daerah Bukit Rawi, (2) anak harus punya kemampuan menolong abah dan mama melalui doa-doa yang dimohonkan kepada Tuhan (Allah SWT) minimal satu kali dalam 24 jam, (3) anak yang nantinya mampu mendidik diri dan keluarganya kelak, mampu membuat kehidupan masa depan lebih tentram dan lebih berkecukupan.

Suban, menurut strukturnya menikah dengan Priscilia, yang semula memeluk agama lain. Suban seorang migran yang meraih sarjana pada tahun 1999, bekerja sebagai PNS dengan tugas tambahan sebagai kepala SD Purwadadi 2 pemukiman transmigrasi dan memiliki sertifikat pendidik tahun 2007, isterinya juga mendapat sertifikat dan tunjangan sertifikasi.

Suban termasuk seorang transmigran muslim yang gigih mempertahankan iman Islam dan berhasil memikat istri menjadi muslim, meskipun orang tua pihak istri adalah seorang tokoh gereja dan pendeta. Suban mengarahkan putra-putrinya menempuh pendidikan pesantren dan sekolah, seperti halnya putra pertama, bernama Citra dan Ahmad. Pendidikan dasar (SMP) dan SMA kedua anaknya dipilihkan di Pesantren Lirboyo, Kediri yang termasuk pendidikan yang menerapkan kurikulum terpadu antara agama dan umum sampai tamat.

Suban dan istrinya termasuk transmigran berpendidikan menengah yaitu SPG. Keduanya memiliki gagasan maju dan harmonis artinya memiliki tekad yang kuat dan meraih pendidikan sampai sarjana meskipun di tengah-tengah kesibukan bekerja PNS di Sekolah Dasar yang terletak pada pemukiman yang jauh dari perguruan tinggi. Gelar sarjana S.1 dan peningkatan kesejahteraan yang melekat pada profesinya sebagai guru telah menjadi kenyataan, suami mendapat tugas tambahan memimpin sekolah dasar dan istrinya sebagai guru yang bersertifikat sehingga suami dan istri memperoleh penghasilan yang dirasa sangat memuaskan karena mendapat gaji dan tunjangan sertifikasi.

Suban, satu-satunya guru Sekolah Dasar yang pertama kali mendapat tunjangan sertifikasi di Dinas Pendidikan Kabupaten Pulang Pisau karena telah memiliki ijazah S.1, jauh sebelum disyahkannya undang-undang tentang kualifikasi guru yang minimal berpendidikan S.1. Selain itu, pernah mendapat tawaran dari Pemda sebagai sekretaris wilayah kecamatan, akan tetapi Suban menolak tawaran jabatan itu sesudah melakukan musyawarah dengan istri, anak dan salat Istikharah sebanyak tiga kali.

Suban menyiapkan lokasi rintisan 
pendidikan pesantern di J1. Cilik Riwut kilometer 19 terletak di Kelurahan Petuk Ketimpun, kota Palangka Raya. Tanah seluas 4.000 meter persegi dengan sertifikat hak milik. Selain tanah itu, di seberang rumah Suban juga tersedia tanah hak milik ukuran 40 x 40 meter di Pangkoh untuk dipersiapkan satu unit Musala dan tiga ruang belajar agama. Suban dan istri mempunyai empat (4) orang anak dan mengarahkan tiga di antaranya untuk belajar ilmu agama kemudian melengkapi dengan ilmu umum, seperti yang di ungkapkan berikut ini:

Anak pertama, Citra Priski Abadi, 23 tahun. Berpendidikan SD, SMP Pesantren Lirboyo dan SMA Pesantren tersebut berkuliah pada jurusan satra inggris semester 8. Sering mendapat tugas untuk membantu dosen pada mata kuliah Penulisan karya ilmiah. Menyelenggarakan kursus bahasa inggris dan membaca Al-Qur'an di rumah ketua RW. Citra memiliki pengalaman menjadi pengurus Ma'had atau pesantren mahasiswa pada semester 2 sampai 7. Ia mendapat beasiswa selama 4 semester berturut-turut. Ia pernah berhasil memperoleh beasiswa untuk belajar bahasa Arab di Maroko tetapi tidak direstui ibunya, sedangkan untuk pertukaran mahasiswa ke Australia juga mendapat hambatan Dana jaminan sebelum pemberangkatan. Anak kedua, Umar Adi, 21 tahun. Menyelesaikan pendidikan SD, SMP pesantren Lirboyo.Suban dan istrinya menyatakan bersyukur dan tetap pada pilihannya menjadi pendidik dan bertempat tinggal di Pangkoh karena dapat menikmati penghasilan yang relatif besar dari gaji dan tunjangan sertifikasi. Selain itu, berada dalam rumah tangga yang tenang, tidak hams menghadapi permasalahan yang kemungkinan muncul dalam waktu 24 jam bertugas sebagai pejabat. Menurut Suban, menjadi pendidik, kehidupan menjadi teratur, terencana, berinteraksi langsung dengan warga masyarakat lingkungan dan orang tua siswa, lain halnya dengan bayangan jika menajdi pejabat kantoran yang pasti menjalani rolling tempat tugas yang perlu dapur kedua.

Keluarga Suban memprioritaskan pemahaman terhadap ajaran agama Islam, sedangkan memelajari ilmu lainnya tetap dianggap penting akan tetapi bukan menempati posisi yang utama. Pemikiran Suban dan istrinya sepakat menitipkan anakanaknya ke Pondok Pesantren yang dipandang memiliki ilmu yang padu, saling melengkapi. Cara pengasuhan anak yang demikian memiliki relevansi dengan pendapat Agus Wibowo, 2012.

Suban tidak pernah mengambil keputusan secara sendiri, mengajak musyawarah dengan keluarga dan meminta petunjuk kepada yang mahakuasa. Diperhatikan dari sikius kehidupan, keluarga Suban sedang berada pada posisi yang membahagiakan. Wujud kebahagiaan itu diakuinya karena telah meraih kualifikasi pendidikan sarjana dan sebagai guru yang bersertifikat, istri yang telah mengenakan busana muslimah, dan menyatakan merasa senang beberapa kali mengunjungi Pesantren Lirboyo di Jawa Timur karena sebelumnya memeluk agama yang lain, selama ini tiga orang anaknya termasuk anak saleh atau baik-baik dan menyenangkan hati orang tua.

Selain Suban, yang juga sebagai pendidik adalah Ghofir yang menyatakan bahwa: berpindah atau bertransmigrasi adalah sebuah keputusan sikap dan perilaku yang penting karena, (1) Transmigrasi menopang anak mendapat pendidikan yang lebih tinggi, (2) Meningkatkan Status Sosial dirinya dan anak-anak, (3) banyak yang sukses meniru jejak Rasullullah yang berhijrah dari tempat kelahiran di Mekah menuju Madinah. Sukses bisa pada orang tua atau anak-anaknya, maka banyak anak yang dapat kuliah.

Anak dari kelaurga Ghofir juga bersekolah dan kuliah. Keluarga Ghofir mempunyai dua anak. Anak pertama, Arief Nurul Aziz, 22 tahun, menyelesaikan pendidikan SD, SMP, SMA, melanjutkan di STIKES program internasional pada 
semester IV. Kedua, Gita Safitri, 12 tahun, kelas VI SD Islam di Pesantren Darul Hijrah, Kalimantan Selatan.

Ghofir memiliki motif tersendiri, Ia bertransmigrasi untuk menopang masa depan anak dan meningkatkan status sosial serta tempat mencari sukses yang diridloi. Pada awal kedatangannya Ghofir berpendidikan sarjana muda Tarbiyah. Ia mengalami beberapa kemudahan di Pangkoh tempat yang baru sejak tahun 1982. Penampilan Ghofir menyenangkan, ramah, suka membantu ${ }^{\circ}$ rang lain, ketika bertemu dengan tamu kapan saja. Ia pasti menyapa "apa kabar?" kepada tamunya, jabat tangan erat-erat dan merangkulnya.

Ghofir, 55 tahun lahir di Slawi Kabupaten Tegal Jawa Tengah, menyelesaikan pendidikan $\mathrm{Si}$ Tarbiyah STAI Kapuas, sekarang kepala SMAN Pandih Batu. Menurut strukturnya, Ia menikah dengan Mustoliah, dari daerah yang sama, lahir tahun 1963. Menyelesaikan pendidikan di STAIN S.1. Istri bekerja sebagai PNS kepala Madrasah Ibtidaiyah swasta di Kecamatan Pandih Batu.

Pendidikan untuk diri-sendiri sebagai orang tua sekaligus pendidik dipandang peioritas karena relevan dengan pekerjaannya, terdapat kesamaan arah dan tindakannya, seperti dikemukakan Duro sebagai berikut:

Duro, 52 tahun lahir di Kediri, sebagai kepala sekolah SD golongan IV/A, bersertifikasi tahun 2011, isterinya bernama Wagirah lahir tahun 1960 menyelesaikan pendidikan SD, SMP, D.2 PGSD, pendidikan S.1 masih dalam tahap penyelesaian skripsi. Menurut strukturnya, Duro mempunyai tiga anak yang berhasil sarjana dan bekerja. Anak pertama, Ani Zulaiha R, 39 tahun. Menyelesaikan pendidikan SD, MTS, SMA, S.1 bimbingan konseling. Bekerja sebagai guru di MTSN Barabai.

Telah berkeluarga dengan Nurrahman S. PdI yang juga bekerja sebagai
PNS guru di sekolah yang sama. Kedua, Nurul Azizah, 31 tahun. Menyelesaikan pendidikan SD, MTS, MAN, pondok pesantren, kuliah akuntansi syariah dan diploma 3 poltekes di Banjarmasin. Bekerja sebagai karyawan perusahaan pada PT. Alun, cabang Banjarmasin heralamat di kilometer 8. Ketiga, Ikhsanuddin Bayu Nurrahman, 29 tahun. Menyelesaikan pendidikan SD, SMP, dan MA pesantren berkuliah di STIKIP S.1 Bahasa Indonesia. Bekerja sebagai asisten dosen pada jurusan tersebut.

Duro dalam rumah tangga menerapkan prinsip-prinsip tertentu sebagai pegangan membina anak-anak. Prinsip tersebut hams menjadi inspirasi dalam kerja, ibadah, dan bermasyarakat. Menurut cara pandang pendidikan, Duro dan istrinya telah melakukan perubahan status, antara lain dari lulusan Sekolah menengah menjadi lulusan Perguruan Tinggi, dan PNS. Putra-putri Duro diarahkan kepada keseimbangan dan berhasil menempuh pendidikan masdrasah termasuk pesantren sebagai modal dasar untuk memiliki karakter sebagai muslim yang baik. Pendidikan yang bukan agama juga berhasil diraih sampai sarjana S.1. Semua putra dan putri telah bekerja sesuai dengan ilmu yang dimilikinya. Anak pertama dan kedua bekerja sebagai PNS di lembaga pendidikan madrasah sedangkan yang kedua bekerja sebagai asisten dosen di sebuah Perguruan Tinggi Swasta berbasis Islam.

Duro dalam keluarga telah menanamkan kebiasaan untuk berbudi pekerti baik, jujur, berani mengemukakan pendapat, berteman dengan yang baik-baik atau soleh, memiliki tata karma serta disiplin melaksanakan ibadah. Pembinaan yang demikian relevan dengan tipe asuhan orang tua yang paranoid (Agus Wibowo, 2012) yaitu orang tua yang memprioritaskan pendidikan untuk anak-anaknya, orang tua beranggapan bahwa melalui pendidikan anak akan mendekatkan kenyamanan dan 
keselamatan. Anak kelak mampu bertahan dalam kehidupan yang kompetitif. Upaya mendidik anak dan berkeluarga seperti Duro memiliki makna yang luhur, selain pendidikan sekeluarga dan karir menigkat sejalan dengan amaliahnya.

Duro dan isterinya telah menunaikan ibadah umroh pada Agustus 2011 dan mendaftar ibadah haji pada awal bulan Mei 2012 berangkatnya masih menunggu panggilan. Dalam kemasyarakatan, Duro dituakan, mendapat amanah sebagai ketua pengurus masjid dan imam tetap pada masjid Attaqwa yang berjarak 100 meter dari rumahnya. Selain mendidik anaknya, juga memiliki anak asuh bernama Martono yang berhasil menyelesaikan pendidikan SD, SMP, MAN, dan S.1 Tarbiyah sekarang menjadi guru agama Islam pada SD yang di pimpin Duro.

Selain mereka yang disebutkan sebelumnya, juga seorang migran yang berpendidikan PGAN, yang bernama Marson punya impian yang menjadi kenyataan. Marson, 44 tahun lahir di Majenang Kebumen selesai pendidikan MI, SMP, PGA, Diploma 2 Tarbiyah dan berhasil Strata 1 Tarbiyah IAIN. Istrinya Mukhlisoh, 42 tahun asal Majenang Cilacap, menempuh pendidikan SD, SMP, SPG Kapuas, Diploma II PGSD, sedang melanjutkan S.1 sambil bekerja sebagai guru SD Negeri Kantan Muara 2 Pangkoh Pandih Batu. Suami dengan mendapat tugas sebagai kepala MTsN Maliku, $30 \mathrm{Km}$ dari rumahnya.

Berjumpa dengan Marson, bisa terkesan seram pada orang yang baru saja jumpa. Siswa banyak merasa takut menanyakan sesuatu kepadanya, apalagi siswa yang mendapat panggilan datang ke ruang kepala MTsN yang dipimpinnya. Tampilan rambutnya yang tersisa sekitar $30 \%$ dari laiknya, itupun hampir seluruhnya memutih, dengan tinggi badan $150 \mathrm{~cm}$ dan gendut, lincah dan tegas, terus terang, berapi-api dan lantang bicaranya. Pak Marson, nama panggilan akrabnya, memimpin madrasah sejak tahun 2007. Marson bermukim di Pangkoh-III/B, bersama istrinya mengelola usaha bisnisnya, toko sembako yang letaknya strategis di samping tiga jalan ke menuju perkebunan kelapa sawit, arah pasar dan dermaga kecamatan dan jalan arah Kota Kabupaten Pulang Pisau.

Marson punya rencana melanjutkan studi pascasarjana Strata-2 pada konsentrasi Manajemen Pendidikan Islam, di IAIN Antasari Banjarmasin tahun akademik 2012/2013, sekitar 3 jam jalan darat dari desanya. Anak pertama, Eka Setia Ningsih, 15 tahun menempuh pendidikan SD, SMP Negeri kelas III akan masuk MAN. Kedua, Zainur Rahman, 7 tahun, menempuh pendidikan SD negeri kelas I.

Marson dan istrinya tidak pernah berhenti menempuh pendidikan, meskipun bekerja dan bertugas di tempat yang relatif susah menjangkau pendidikan tinggi. Anaknya masih menempuh pendidikan dasar dan menengah. Sementara itu, Marson dan istri memanfaatkan dana dan hasil kerja untuk meningkatkan kualifikasi pendidikannya sendiri, karena kedua anaknya memerhikan biaya pendidikan yang relatif kccil.

Usaha toko sembako, yang ramai dikunjungi para pembeli karena berbagai kelebihan yang dimiliki oleh Marson dan istrinya. Istrinya termasuk guru yang suka bermasyarakat, giat dalam organisasi di Pangkoh, demikian pula Marson yang tidak pernah menolak ketika diminta oleh warga masyarakat untuk menyampaikan ceramah agama. Cara yang dimiliki Marson maupun istrinya relevan dengan tuntunan agama Islam mengenai usaha dan kemasyarakatan serta mencari ilmu yang tiada batas, dari buaian sampai keliang lahat.

Peningkatan pendidikan yang diraih Marson dan istrinya membawa peningkatan pendapatan dan pengaruh yang menguntungkan misalnya dengan meningkatnya kepercayaan Kantor Kementerian Agama yang menugasi 
menjadi kepala MTsN dan istrinya yang suka bermasyarakat sehingga usahanya terdukung oleh citra baik dari masyarakat, maka terjadi peningkatan pendapatan, yang berujung pada kemakmuran. Marson termasuk seorang ayah yang mampu memanfaatkan peluang pendidikan. Ia tidak menunda mencari ilmu di masa muda ketika putra-putrinya belum memerlukan banyak biaya, kondisi badan masih tegar, kemampuan berpikir dan mengingat masih kuat, relevan dengan kandungan sebuah syair yang maksudnya: gunakan masa mudamu sebelum masa tua, gunakan masa sehatmu sebelum datang masa sakitmu.

b. Mencari ilmu Agama yang pertama dan mencari ilmu dunia yang kedua

Dulfa, 58 tahun seorang migran di Pangkoh yang berlatar belakang pendidikan awalnya PGAN. Dulfa, menempuh pendidikan MI, I'ondok Pesantren, PGAN, dan S.1 Tarbiyah STAI Kapuas. Menikah dengan Solehah seorang guru SD lulusan D.2 PUSD, sebagai PNS guru di SDN 2 Pangkoh III-blok A. Dulfa dan solehah memiliki 3 orang anak yaitu Siti Aminah, M. Saefudin A. Majid, dan Abdul Zaeni. Solehah meninggal dunia pada Nopember tahun 2011, sehingga Dulfa menikah yang kedua kalinya dengan S.Pd, 45 tahun seorang PNS dan Kepala Sekolah Dasar di Pangkoh II-Blok A.

Ayah Dulfa menghendaki, anaknya untuk menuntut ilmu umum dan ilmu agama, seperti mewarisi apa yang dimau oleh mbah. Menurut Dulfa, mencari kekayaan itu nomor dua, yang terpenting adalah pendidikan, sesuai dawuh-he kanjeng Nabi. Ilmu yang di punya digunakan untuk makmur - sejahtera di dunia dan untuk senang selamat akhirat, kalau mau selamat dunia dan akhirat harus punya dan pakai ilmu, tidak ada yang pakai harta. Itulah sebabnya, anak cucu mewarisi dari orang yang terdahulu atau bisa dikatakan dari nenek moyang, sampai sekarang. Menyekolahkan anak meskipun atas keinginan sendiri tetapi tidak lepas dari kaitan dengan apa yang di contohkan kanjeng nabi.

Sementara itu dalam masyarakat masih ada orang yang punya anggapan keluarga orang Banjar yang dikenalnya, lebih suka anaknya diarahkan ke sekolah yang mengandung ajaran agama seperti pesantren, pondokan dan madrasah yang memprioritaskan agama dari pada sekolah pada umumnya.

Menurut Dulfa, Anak-anak terutama laki-laki pada keluarga migran muslim harus sarjana, mencari ilmu yang pertama adalah mencari ilmu agama, yang kedua ilmu dunia. Anak disekolahkan di Pesantren alFalah selama dua (2) tahun, kemudian dipindahkan ke MAN Maliku sampai lulus. Pesantren yang ditempati anak saya dulu dikelola sangat bagus, tetapi kurikulumnya memang "lama ditempuh", sehingga anakanak santri yang menjalani pendidikan hams tabah dan sabar. Artinya tak bertarget, kalau menempuh pendidikan sampai lama, mendapat banyak berkah dari guru, ilmu yang diajarkan melekat kuat. Bersekolah di sekolah umum, mudah sekali terpengaruh hal-hal yang negatif dan bermacam-macam dibandingkan dengan sekolah agama.

Anak pertama, Siti Amin* 25 tahun menyelesaikan pendidikan SD, MTs, Pesantren Darul Hijrah, MA, dan S.1 pendidikan agama Tarbiyah STAIN Palangka Raya, lulus tahun 2011. Bekerja sebagai guru honorer pada TK Perwanida Kanwil Kementerian Agama Kalteng. Kedua, M. Saefudin A. Majid, 22 tahun. Menyelesaikan pendidikan SD, MTs, SMA, dan dalam proses penyelesaian S.1 pendidikan Biologi FKIP UNPAR. Ketiga, Abdul Zaeni, 21 tahun menyelesaikan pendidikan SD, MTs, SMK Otomotif dan Semester 8 Fakultas Teknik UNPAR dan FKIP PJO universitas PGRI semester VII.

Dulfa sebagai seorang guru agama mengutamakan penanaman agama kepada anak-anaknya pada usia remaja mulai dari 
MTs sampai menengah. Bagi anak perampuan diarahkan untuk mendalami ilmu agama di Pesantren karena dipandang akan menjadi pendidik dalam rumah tangga khususnya anak-anaknya sendiri yang lebih dekat kepada ibu dari pada ayahnya. Bagi anak laki-laki, menurut Dulfa diarahkan kuliah ilmu umum karena harus bertanggungjawab untuk mencari nafkah, yang demikian relevan dengan pembagian tanggung jawab antara suami dan istri. Dulfa mengidealkan kemampuan anaknya di bidang agama yang praktis seperti kemampuan membaca al-Qur'an, mengimami salat dan melafalkan dalil alQur'an maupun Hadist lebih baik daripada kemampuan yang dimiliki oleh orang-orang yang berada di lingkungannya, akan tetapi merasa belum puas dengan output pendidikan yang dimiliki pemerintah meskipun keluaran dari lembaga pendidikan agama, yang dikagumi adalah output dari pondok pesantren yang diakui telah mencapai kepentingan praktis bagi masyarakat khususnya umat Islam.

Menurut konsep Islam, anak dilatih melakukan salat pada usia tujuh (7) tahun, dan pada usia sepuluh (10) tahun orang tua boleh memukul anak bila anak tidak melaksanakan ibadah salat. Pada sisi lain, dalam hal mencari ilmu harus dilaksanakan sepanjang hayat dari masa anak-anak, masa remaja, masa dewasa hingga masa tua. Mengenai materi ilmu yang dicarinya adalah ilmu pengetahuan agama Islam - tafaqquh fidden - yang mampu membimbing anakanak remaja dan orang dewasa sepaya tetap dalam iman dan Islam, serta materi ilmu lain yang dapat dituangkan sedemikian rupa untuk pembangunah, percepatan, perbaikan pendapatan, peningkatan kualitas hidup umat, tcrmasuk kesejahteraan keluarga dan anak serta family, sehingga mampu membantu orang lain dan mampu melaksanakan ibadah yang membutuhkan dana relatif besar, seperti ibadah haji dan sej enisnya.

Selain itu, Hamian salah seorang migran yang gigih dan punya kelebihan sebagai Qori, menempuh pendidikan sampai meraih gelar Magister. Hamian, 55 tahun lahir di Kediri, belajar di MI pesantren sampai dengan Madrasah al-Wustha, orang tua bertransmigrasi. Hamian melanjutkan pendidikan SMP persamaan dan SMA paket C bersamaan dengan bekerja sebagai staf pada kantor Departemen Agama (sekarang Kantor Kementerian Agama) Kapuas.

Melanjutkan kuliah S.1 Tarbiyah STAI Kapuas dan pendidikan S.2 program studi Administrasi Publik di Universitas Brawijawa Malang, selesai pada tahun 2011 mendapat bantuan sebesar $50 \%$ kebutuhan dana pemerintah daerah Pulang Pisau. Hamian menikah dengan Siti Aisyah asal Banjarmasin, Aisyah bekerja sebagai PNS guru agama SD dengan latar belakang pendidikan SD, PGA, dan S.1 Tarbiyah STAI. Aisyah memperoleh status guru bersertifikat pada tahun 2010, dan mendapat tunjangan pertama cair pada awal tahun 2011. Keluarga Hamian dikarunai tiga (3) putra seperti dijelaskan berikut ini:

Anak pertama, Ahmad Basir 28 tahun, menyelesaikan pendidikan SD, MTs, dan MA di Pondok Pesantren al-Fallah. Pendidikan S.1 di selesaikan di Fakultas Syariah jurusan al-Ahwalussasiyah IAIN Antasari Banjarmasin. Bekerja sebagai PNS pada kantor kementerian agama Kapuas. Kedua, Ahmad Baidowi, 27 tahun, menyelesaikan pendidikan SD, MTs, dan MA di Pondok Pesantren al-Fallah. Pendidikan S.1 di selesaikan di Fakultas Ussuluddin jurusan PerbandinganAgama IAIN Antasari Banjarmasin. Menghonor di kantor Kemenag Pulang Pisau. Ketiga, AbdulFatah, 20 tahun, menyelesaikan pendidikan SD, MTs, dan MA di Pondok Pesantren al-Fallah. Pendidikan S.1 dalam proses di Fakultas dakwah Jurusan Komunikasi dan Penyiaran Islam IAIN Antasari Banjarmasin.

Hamian memilihkan pendidikan anaknya dengan pendidikan agama, dimulai dari pendidikan dasar sampai impian jadi 
sarjana. Ketika pendidikan dasar, semua anak dipercayakan kepada pondok pesantren. Kelanjutan kuliahnya juga berkait erat dengan pendidikan sebelumnya sehingga tidak ada keluhan atau hambatan akademik yang berarti pada anak-anaknya. Semua anaknya mendapat jaminan biaya pendidikan dari orang tua secara penuh, berbeda dengan anak-anak transmigran Pangkoh lainnya. Kondisi ekonomi kelnarga Hamian bisa dikatakan termasuk mapan, Hamian seorang sarjana bekerja sebagai Naib atau Kepala KUA, golongan VI/A dan istrinya Aisyah yang juga PNS yang berstatus pendidik bersertipikat.

Lebih dari itu, Hamian mendapat kesempatan dan dukungan dana dari Bupati Pulang Pisau dan beberapa pejabat pemerintah daerah menempuh pendidikan S.2, sehingga Hamian menyelesaikan dan mendapat gelar akademik M.AP. Ia suka bekerja keras sejak golongan $\mathrm{I} / \mathrm{B}$ dan pengalamannya menajdi juara MTQ pada beberapa even tingkat kabupaten dan provinsi. Aktivitas ibadah Hamian dan istri termasuk meningkat, mampu bersyukur dan sudah menunaikan ibadah haji bersama istri.

Hamian menempatkan pendidikan agama sebagai prioritas untuk semua anaknya dengan impian sarjana S.1 minimal. Hamian mengakui telah mendapat rizeki yang banyak dari yang mahakuasa sebagai buah dari kebiasaan member memudahkan kepada orang, gigih dan kerja keras menempuh pendidikan tinggi selain melaksanakan tugas sebagai PNS. Hasil kerja Hamian diakui relatif melimpah, sehingga dapat digunakan untuk membiayai pendidikan anaknya, membantu dua orang kemenakan yang sedang mengaji di pesantren, merawat ayah kandungnya yang sudah sepuh, dan membantu biaya hidup ibu kandungnya yang masih ingin mendanai meskipun keduanya berdekatan rumah dengan Hamian.

Sebagai tanda syukur, Ia sudah merencanakan memberangkatkan anak yang ketiga ibadah umroh bilamana telah menyelesaikan pendidikan sarjana S.1 dan memotivasi anak pertama studi ke Pascasarjana Antasari B anjarmasin.

Hasyim menempuh pendidikan dasar dan menengah di Blitar, khusus untuk mengikuti ujian MAN di jalaninya sesudah pesantren selama enam tahun sehingga mengaku mudah menyelesaikan ujian Madrasan Aliyah, demikian juga ketika menj al ani perkuliahan pada jurusan pendidikan agama Islam juga tidak banyak kesulitan. Selain kuliah, waktu diatur secara ketat karena harus bekerja dan mengambil upah bersama kawan-kawan lain dan seniornya. Sedangkan semasa di pesantren biaya ditanggung orang tua sepenuhnya.

Menurut konsep Islam, orang tua Hasyim menanamkan dan mengutamakan pendidikan agama serta melengkapinya dengan ilmu umum. Ketika di Pesantren materi pelajaran dan aplikasinya dalam bentuk perkataan, perbuatan, ibadah dapat berangsur-angsur langsung dibiasakan. Lain lahnya dengan memperoleh ilmu pada lembaga pendidikan yang ansih sekolah. Konsep Islam tentang keseimbangan menjadi sebuah alternatif penyiapan anak didik, artinya keseimbangan antara pemahaman terhadap agama dan ilmu pengetahuan yang bukan agama dilakukan secara berimbang. Memahami ilmu umum tanpa memahami ilmu agama adalah bagaikan orang buta sedangkan menguasai ilmu agama tanpa memahami ilmu umum adalah kepincangan (Mukti Ali, 1999, halm. 10).

Dalam masyarakat, Hasyim diakui sebagai sesepuh, menjadi tempat bertanya dan berdialog warga masyarakat transmigran yang membutuhkan solusi dari masalah agama Islam. Didukung oleh istrinya yang merlatar belakang profesi kebidanan, tetapi berlainan persoalan. istri menjadi tempat warga masyarakat transmigran mengatasi masalah kesehatan yang dialaminya. Dengan demikian, dalam rumah tangga Hasyim 
terdapat dua fungsi sosial, yaitu fungsi layanan pengobatan lahiriah dan fungsi kelslaman yang ditangani oleh Hasyim, sedangkan fungsi pengobatan lahiriah atau fisik ditangani oleh istrinya. Kondisi rumah tangga seperti menerima tamu tidak terbatas pada jam dan hari tertentu, akan tetapi terbuka dan melayani sepanjang hari dan tidak menolak ketika tamu datang di tengah malam, atau yang dituju sedang istirahat.

Menurut konsep Islam, menolong atau membantu orang lain yang sedang menghadapi masalah adalah sebuah kebajikan, termasuk mambantu warga yang meminta pendapatnya karena suatu masalah, mengenai ibadah atau muamalah. Demikian juga membantu mencarikan solusi bagi warga yang sakit atau memerlukan pertolongan persalinan juga termasuk kebajikan.

Kebiasaan membantu orang lain dapat menimbulkan kesan positif atau citra baik bagi scscorang dart pihak yang dibantu. Kepercayaan pihak yang dibantu tumbuh dan meluas kepada orang-orang yang berkomunikasi dengannya karena sifat suka menolong, mambantu orang lain, sehingga orang lain menjadi terhindar dart kesulitan. Selain itu, Ia semakin mantap terhadap apa yang dikatakan, yang dijanjikan dan yang dicontohkan. Hal ini relevan dengan kandungan isi pendidikan karakter di mana setiap orang harus jujur, berkata benar, dapat dipercaya, toleran, kreatif, percaya dirt dan pantang penyerah, memiliki rasa kasih sayang, dan peduli terhadap kepentingan orang lain (Mulyasa, 2011).

Dalam keseharian, Hasyim 40 tahun, pakaian yang disuka adalah mengenakan pecis warna hitam, baju koko warna putih dan sarung tenunan samarinda, atau kemeja batik keris ketika menerima tamu di rumahnya. Celana dan motif baju yang dikenakannya selalu serasi, ketika baru jumpa bersalaman dengan erat-erat disertai cepat-cepat merangkul, suka mengucapkan assalamu'alaikum ketika mengajak seseorang memulai membicarakan sesuatu dengan tamu di rumahnya. Hasyim berperawakan tinggi $165 \mathrm{~cm}$, kulit tampak putih bersih, murah senyum, bibir tipis, rambut hitam tebal, berjabat tangan disertai genggaman yang kuat dan sorot mata yang menatap sambil sesekal; merangkul bagi yang sudah lama tak jumpa.

Hasyim dan istrinya yang sehariharinya sebagai bidan desa tarnsmigran sejak tahun 1985 membuka pintu rumah selama 24 jam untuk siapapun yang ingin bertemu Hasyim atau menemui bidan karena kepentingan kesehatan fisik. Sedangkan orang yang bertamu dengan Hasyim hampir semua berurusan dengan ibadah, akidah, muamalah yang berdasar ajaran Islam. Hasyim memiliki kekebiasaan menerima tamu sampai larut malam membicarakan persoalan kemasyarakatan dan keislaman termasuk memilih sekolah Islam, pesantren, madrasah dan ketreampilan hidup. Penampilannya mcnarik, suara lembut, dan santun. Selain itu, Hasyim memiliki ketrampilan terapi urut refleksi total yang memerlukan waktu sekitar dua (2) jam secara terus menerus meskipun imbalan jasa seikhlasnya.

Salah seorang migran yang berinisial Rusdianto, 53 tahun memiliki riwayat pendidikan awal, SPG tetapi mempunyai garis tangan yang lebih membanggakan daripada kawan migran seangkatan sesudah lulus sarjana S.1. Ia pernah bertugas sebagai guru SD, kepala SD, guru SMP, kepala SMPN 2 dan sekarang mendapat tugas sebagai kepala SMKN Perintis berbasis Jaringan Komputer di Pandih Batu. Istrinya bernama St Rahmah yang memiliki pendidikan awal SPG, asal Sulawesi, bekerja sebagai PNS Guru SD yang memiliki tiga (3) orang anak -yang menjadi sarjana dan abdi Negara.

Rusdianto dan anaknya memilih lembaga pendidikan yang khas pendidikan keguruan karena mendidik anak merupakan kebajikan yang nilai kebaikannya tiada akhir. Lebih daripada mendidik anaknya sendiri karena mendidik anak orang lain di 
kelas atau di sekolah didasari oleh rasa tanggungjawab profesinya. Bekerja sebagai pendidik menurut Rusdi sangat mulia, selain meningkatkan kemampuan anak didik tanpa terasa dan berlangsung secara alami meningkatkan jumlah pengetahuan" yang dimilikinya, dirinya didesak dengan kepentingan untuk mencari pengetahuan yang ba' dan dikagumi sehingga punya daya tank tersendiri. Pengetahuan yang barn disesuaikan dengan kebutuhan siswa dan kemajuan ilmu pengetahuan

Termasuk penggunaan alat-alat pendidikan yang dapat mempercepat diperolehnya ide-ide dan temuan penelitian dari lembaga pendidikan lainnya yang relevan dengan perkembangan pembelajaran, media dan sejenisnya.

Rusdi mengakui dengan menjadi pegawai (guru negeri) menjadi banyak dikenal karena pertemuan antar pendidik, pertemuan dengan wali siswa, pertemuan dengan siswa yang setiap tahun bertambah. Ini semua memotivasi dirinya untuk melakukan yang baik, berkarakter, dan bisa dijadikan figur bagi siswa dan masyarakat lingkungan.

Dengan demikian, seorang pendidik hams mampu mengendalikan din perilakunya, menjadi contoh dalam beragama, berilmu dan beramal. Lebih mulia bilamana seorang guru bisa memberiikan keteladanan kepada warga di lingkungannya dan meraih pendidikan kelompok siswa yang memiliki prestasi lebih tinggi tetapi terkendala dengan biaya pendidikan. Pasangan rusdiangan dan St Rahmah memiliki tiga (3) anak yang berhasil meraih pendidikan sarjana strata satu (1), Rusdi dengan berapi-api dan bangga menj el askan

Anak pertama, bernama Siti Mutmainah, 28 tahun lulusan SD, SMP, SMA, S.1 pendidikan matematatika. Ia bekerja sebagai PNS guru matematika di SMPN III Palangka Raya. Bersuami dengan Suratno, S.Pd., seorang guru IPA di sekolah yang sama. Memiliki satu orang anak berusia 2 tahun. Kedua, Hartono, 25 tahun, lulusan SD, MTs, MAN, dan sarjana S.1 Pendidikan Bahasa Inggris. Bekerja di SMAN Maliku sebagai CPNS dan belum berkeluarga. Kedua, Hartono, 25 tahun, lulusan SD, MTs, MAN, dan sarjana S.1 Pendidikan Bahasa Inggris. Bekerja di SMAN Maliku sebagai CPNS dan belum berkeluarga.

Lain halnya dengan Nurso 42 tahun, dan Winda 40 tahun yang memandangnya menjadi kewajiban orang tua menyekolahkan anak-anaknya. Nurso memilihkan pendidikan anaknya pada lembaga pendidikan umum. Menurut pendapatnya pendidikan ini lebih luas jangkauannya dan lebih banyak kesempatan kerjanya. Nurso dan istrinya memiliki ide yang sama bertekad untuk memberikan bekal pendidikan sampai sarjana, bukan memberikan harta warisan. Harta warisan menurut Nurso sangat relatif dan tidak stabil artinya mudah mengalami perubahan antara ada dan habis, berbeda dengan kepemilikan ilmu atau pendidikan yang melekat sepanjang hayat.

Manfaat pendidikan dipandang lebih stabil artinya selalu ada dan tidak habis dipakai. Hal demikian, sejalan dengan yang dialami Nurso setelah membandingkan dua kondisi antara susah mencari penkerjaan di daerah asalnya dengan keadaan sekarang di Pangkoh setelah memperoleh status sebagai guru tetap. Lebih lagi istri, Winda, yang cangkal, gigih, suka kerja keras. Ia mengelola jasa layanan kantin $\mathrm{dm}$. mengurus rumah tangga, meskipun tidak sempat menjadi seorang abdi Negara.

Oleh karena itu, Nurso merasa syukur dan harus membekali,pendidikan kepada anak untuk masa depan. Asset yang dimiliki Nurso memang secara kuantitas, belum melimpah masih menetap di rumah dinas guru, memelihara ternak besar sebagai tunjangan keluarga, rumah yang Baru memang sudah siap dihuni terletak berada di 
luar lingkungan sekolah (SMP). Rumah tersebut masih disewakan kepada guru barn yang bertugas di sekolah tersebut. Karena bilamana melanjutkan jasa kantin di rumah yang barn itu akan menglami pasang dari surut pelanggan yang drastis karena relatif jauh dari lingkungan sekolah dan siswa tidak datang ke sana.

Anak pertama, Khusnul, 23 tahun, menyelesaikan pendidikan SD, SMP, SMA IPA, melanjutkan ke FKIP PNPAR. Sambil bekerja di pusat perbelanjaan Mega Top Trade Center di Jln. Yos Sudarso $1 \mathrm{~km}$ dari kampus dimana Ia kuliah.

Kedua, Nana Nurdiana, 19 tahun, menempuh pendidikan SD, SMP, SMA, kuliah di tadris Bahasa Inggris STAIN Palangka Raya semester IL Ketiga, Akbar Kurnia, 13 tahun, bersekolah kelas I SMP-1 Pandih Batu, keempat, Ilham Krisnamukti, 11 tahun, masih bersekolah di kelas $\mathrm{V}$ di Pangkoh Besarnya pendapatan keluarga Nurso sudah meningkat. Peningkatannya terlihat dari beberapa aspek, antara lain kualifikasi pendidikan Nurso sedang menempuh pendidikan jenjang sarjana untuk S.1, Universitas Terbuka, mengulialikan dua orang anak, punya rumah yang barn, dan memiliki usaha jasa kantin. Nurso bin Masduki 42 tahun, menyelesaikan pendidikan SD, MTs dan SMA serta D.3 IPS di IKIP Semarang. la berangkat ke Pangkoh karena susah mendapat pekerjaan di daerah asalnya Kendal Jawa tengah. Awalnya, Nurso bertemu dengan salah seorang family bernama Ghofir yang telah menjadi guru agama Islam di SD (Ghofir sekarang sebagai kepala SMAN 1 Pandih Batu). Nurso tertarik mengikuti saran-saran Ghofir dan menyusul ke Pangkoh sekaligus menumpang di rumahnya selama 1 tahun, menghonor sebagai guru IPS di SMPN. Mendapat pengangkatan sebagai PNS di sekolah sampai sekarang. Nurso berkeluarga dengan Winda, 40 tahun yang lahir, dibesarkan, menyelesaikan pendidikan SD, SMP, SMA di Kendal. Ia bersama suami dan dua anaknya bertempat tinggal di rumah dinas guru SMP I, mengelola usaha kantin SMPN. Selain sebagai guru, Nurso masih memelihara 4 (empat) sapi di belakang rumahnya yang berjarak 15 meter. Nurso mengaku bersyukur pindah dari Kendal sudah mengalami perubahan besar. Dahulu Nurso selama 1,5 tahun membantu pekerjaan kedua orang tua, karena belum mendapat pekerjaan yang relevan dengan kuliahnya, dengan merantau ke Pangkoh malah mudah mendapat pekerjaan dan punya penghasilan yang tetap, maka suami dan istri sepakat agar Nana dan semua anaknya dikuliahkan minimal sampai S.1.

Nurso dan Bandi, memiliki provesi yang berbeda tetapi memiliki kesamaan etos menempuh pendidikan untuk dirinya dan untuk anaknya. Bandi, 47 tahun lahir di Kediri, menempuh pendidikan SD, SMP, SMA, pendidikan Bahasa Inggris FKIP UNPAR tidak diselesaikan, tetapi Ia berhasil sarjana S.1 Administrasi Negara FISIP UM Palangka Raya. Bandi punya kegemaran pada kegiatan organisasi, dari organisasi kemahasiswaan sampai dengan partai politik, Partai Golkar sedangkan Nurso bertekun pada pekerjaan rutin sebagai pendidik, menaati aturan disiplin mengajar, membuat RPP, masuk dan keluar dari kelas tepat waktu, sedangkan, kelanjutan dari penggalamannya, Bandi menjadi anggota DPRD Kota Palangka Raya periode, 2004 pertama dan sekarang periode dua. Bandi menikah dengan Khadijah, 37 tahun, lulusan MI, MTs, MA dan S.1 pendidikan Bahasa Indonesia FKIP UNPAR. Bekerja sebagai ibu rumah tangga dan guru honorer di SMPN 8 Palangka Raya. Pasangan Bandi memiliki tiga (3) anak yang kesemuanya perempuan, yang pertama sekolah di MTsN model kelas III, kedua SD kelas VI, dan yang ketiga SD kelas II.

Ketika kuliah pada semester pertama, Bandi bisa membayar regestrasi SPP kemudian pada pembayaran regestrasi kedua, tidak bisa lagi membayarnya. Ia mencari kerja seperti kerja bangunan, tukang sapu dan mengangkat getah karet dari 
Sungai Kahayan untuk dimuat dalam truck perusahaan. Pengalaman kerja di kantor KNPI sebagai tukang kebun dan staf administrasi, menjadi anggota legislatif. Bandi juga aktif di organisasi kepengurusan transmigrasi yang disebut Persatuan Anak Transmigran Republik Indonesia (PATRI) cabang Kalimantan Tengah dipimpin oleh Bapak Sukadi. Tujuan dibentuknya pengurus cabang PATRI adalah untuk membangun daerah oleh anak-anak trans dan mengembangkan potensi anak tranmigran.

Bandi menempuh pendidikan umum sampai dengan Sarjana S.1, sedangkan istrinya menempuh pendidikan pada lembaga pendidikan agama, dari ibtidaiyah sampai dengan Aliyah sedangkan sarjana S.1 tetap pendidikan umum. Bandi bekerja sebagai seorang politisi sedangkan istrinya bekerja sebagai seorang pendidik. Selama menempuh pendidikan, Bandi tidak pernah memperoleh dukungan financial yang memadai karena sambil bekerja dan mengambil upah. Bandi menjadi aktivis dalam organisasi kemahasiswaan dan organisasi di luar kampus. Usai menyelesaikan kuliahnya Bandi memperoleh peluang dengan mudah untuk menjadi anggota legislatif dari Partai Golkar.

Menurut sudut pandang psikologi pendidikan, Bandi termasuk orang yang achiever atau orang yang punya karakteristik tidak mau gagal, pantang mundur dan tents maju. Selain mengejar prestasi, Bandi juga orang yang sangat gigih menjalani pendidikan dan sekarang menggunakan ilmu yang didapatnya untuk bekerja. Dalam konsep Islam, setiap orang harus kerja keras termasuk mencari ilmu, karena dengan ilmu akan memperoleh harta, dengan ilmu seseorang akan memperoleh tahta atau jabatan dan dengan ilmu pula seseorang akan memperoleh derajat atau kedudukan atau posisi tertentu, ataupun pengkat yang lebih tinggi dari pada orang-orang yang tidak memiliki ilmu.

Ilmu yang dimaksud ada dua aspek yaitu ilmu keIslaman dan ilmu keduniaan, dari ilmu itu pula memperoleh pekerjaan, penghasilan, dan kesejahteraan. Apa yang didapat oleh Bandi sesudah memiliki ilmu dan pengalaman, Ia mendapat pekerjaan sebagai anggota legislatif sampai dua periode atau menjadi figur publik di Kota Palangka Raya yang sangat dikagumi oleh keluarga dan masyarakat migran Pangkoh, karena ada ikatan batin yang terbina melalui kunjungan silaturahim ke sanak saudara dan tempat ibadah di Pangkoh.

Bandi dalam keluarganya terlihat berbeda dengan Nurso, Ghofir ataupun Duro yang pulang kerja dan istirahat dapat terencanakan termasuk bersama-sama makan siang dan makan malam serta pulang kerja, sedangkan Bandi dapat dikatakan sebaliknya, karena seorang politisi sering harus bekerja yang tidak terbatas bada delapan (8) jam kerja atau lebih. Menurut pandangan orang lain termasuk penyusun, Bandi sudah sukses besar dibidangnya, tetapi dia masih menyatakan bahwa :

Sampai saat ini belum mencapai kesuksesan. Memang sudah mengakui dan menyatakan berkali-kali rasa syukurnya dengan kedudukan dan penghasilan yang selama ini telah didapat, namun belum sempat menunaikan ibadah haji karena masih mengalami kesulitan mengatur waktu dari padatnya pekerjaan di tempat kerjanya. Bandi juga merasa berbahagia dan beruntung berkeluarga dengan Khadijah yang selama ini sangat setia mengurus dan mendidik anak-anak karena Bandi sering bertugas dan kesibukannya yang menyita waktu sering sampai lewat tengah malam.

Pasangan Bandi- Khadijah mendapat karunia tiga (3) orang anak yang masih remaja yaitu: Anak pertama, Sabariyah, 16 tahun, pendidikan SD, dan MTs kelas III. Anak kedua, Ahmad Baihaki, 14 tahun, berpendidikan SD, MTs kelas II. Anak ketiga, Muzaki, 11 tahun, pendidikan MIN kelas VI.

Hasyim dan Sukar mempunyai 
pengalaman yang menibakan. Awalnya datang ke Pangkoh tidak memiliki orang tua, sedikit berbeda, Hasyim datangnya sudah remaja dan lulus madrasah Aliyah sedangkan Sukar tiba dilokasi mencari ayah ibunya, masih berusia 12 tahunan atau lulus $\mathrm{SD}$, menempuh perjalanan kapal selama enam (6) malam, Sukar menuturkan :

Sukar, 32 tahun, lahir di Lampung Utara. Menempuh pendidikan SD di Lampung, SMP dan SMAN 1 di Pangkoh, langsung bekerja selama dua tahun di hutan. Melanjutkan ke program D.2 STAIN Palangka Raya. Mengajar di SMP 3 Pandih Batu dan mengikuti kuliah universitas terbuka jurusan IPS. Membiayai adik ipar yang sekolah di kelas 2 SMK Tehnologi Kapuas dan MAN Palangka Raya.

Sukar disarankan kakaknya, yang juga warga transmigrasi di Lampung untuk berpindah ke pemukiman warga trans yang baru, menyusul orang tua yang sudah menetap di Pulang Pisau. Sukar diantar kakak naik bus, menuju Pelabuhan Tanjung Priok Jakarta, ikut kapal Taut tujuan ke Pelabuhan Trisakti Banjarmasin, rute pelayaran kapal menyusuri sungai menuju Pelabuhan Kapuas, kemudian merapat di Dermaga Pandih Batu, untuk bertemu orang tua memerlukan waktu 1 jam berjalan kaki di pemukiman Pangkoh. Perjalanan ini memakan waktu enam (6) malam, tetapi dengan senang hati di tempuh karena punya harapan nanti di Pangkoh sekolahnya mendapat dukungan orang tua, akan tetapi orang tua kembali ke Jawa karena alasan keluarga, khususnya orang tua ibu yang sakit keras dan sangat menunggu kedatangannya, sehingga Sukar seorang diri di Pangkoh.

\section{Etos Pendidikan pada Keluarga Migran Berpendidikan Dasar di Pangkoh}

(1) Dua orang Haji yang optimis dan sukses berbisnis

Disamakan dengan haji yang bernama Hadar, 72 Tahun, lahir di Kebumen, berhasil menyelesaikan Sekolah Rakyat. Istrinya yang bernama Martinem, lahir di Kebumen 66 tahun yang lalu. Keduanya dikaruniai enam (6) orang anak, tiga orang anak perempuan dan tiga orang laki-laki.

Anak pertama, Winarsih 51 tahun, selesai pendidikan: SD, SMP, SMA. Bersuami Yusran, 54 tahun guru agama Islam SDN Pangkoh-II blok B. Kedua, Winarni 50 tahun, menyelesaikan pendidikan: SD, SMP, SPP. Bersuami Rustam, 50 tahun lulusan STM, pekerjaan dagang sayur. Ketiga, Winarti 48 tahun, menyelesaikan pendidikan: SD, SMP, SMEA. Menikah dengan Rohim lulus SMEA, bekerja dagang. Keempat Wahyu Hidayat 46 tahun, menyelesaikan pendidikan: SD, SMP, SMA. Menikah dengan Mariah, yang bekerja sebagai pedagang sayur. Kelima Rahmat Hidayat 43 tahun, menyelesaikan pendidikan: SD, SMP, STM. Menikah dengan Ruminah, bekerja sebagai pedagang sayur. Suaminya mengembangkan usaha perkebunan kelapa sawit. Keenam Teguh Setiawan 40 tahun, menyelesaikan pendidikan: SD, SMP, SMEA. Menikah dengan Sunarti, bekerja dagang. Teguh memimpin usaha pengembangan perkebunan kelapa sawit bersama kakaknya.

Anak pertama sampai ke lima lahir di Lampung, sedangkan anak ke enam yaitu Teguh lahir di Pangkoh. Diperhatikan dari aspek pendidikan, Hadar, cenderung memilih lembaga pendidikan untuk putra dan putri pada ketrampilan kerja untuk mendekati masa depan. Masa depan yang dipersiapkan masih relevan dengan kondisi kehidupan pada awal dasawarsa pertama dari kehidupan susah ke arah yang mudah tidak susah memenuhi kebutuhan sandang, pangan dan papan. Kondisi kecukupan terlihat pada pemenuhan kebutuhan dasar keluarga, seperti mencukupi pangan, tempat tinggal, pakaian dan kesehatan, karena keluarga ini termasuk keluarga besar, dengan enam anak dan ayah-ibu yang menjadi delapan orang, oleh karena itu, memenuhi kebutuhan dasar keluarga 
diposisikan sebagai prioritas.

Sementara itu, pendidikan tinggi tidak dipandang perlu dan tidak mendesak, bahkan orang tua mengaturnya dengan mencegah semua anaknya berkuliah, terdapat semacam kecemasan mengganggu usaha yang telah dirintis. Rasa cemas yang diperhitungkan adalah terjadinya rasa irihati di antara putra-putrinya yang berujung pada apa yang disebut pilih-kasih dan ketidakadilan yang dapat menjadi benihbenih beda pendapat, antara kerja kasar dan kerja lembut dalam keluarga besar. Pengelolaan keluarga seperti ini pada zaman dan kurun waktu di bawah tahun 2000 dan kondisi kebutuhan jangka pendek masih dipandang wajar.

Kehendak orang tua membuahkan hasil yang luar biasa dalam bidang finansial atau bisajadi pada kesejahtcraan keluarga secara materi. Usaha keluarga Hadar menguat dan meluas dengan indikasi omsetnya yang menjadi terbesar di wilayah Kecamatan Pan' dih Batu sampai akhir 2011.

Keberhasilan ini pada sisi agama dan kemasyarakatan memiliki makna bagi sesama muslim dengan dibangunnya masjid dan tiga ruang belajar agama digunakan belajar baca-tulis al-Qur'an di Pangkoh IIIblok B. Kegiatan lain adalah di tempat ini juga secara rutin diselenggarakan penyembelihan hewan kurban sejak 8 tahun terakhir. Selain itu, semua cucu motivasi yang sedikit berbeda, simbah memberi beasiswa untuk pendidikan sampai sarjana. Sebagai keluarga besar yang muslim, Hadar, menggunakan sebagian hartanya untuk menunaikan zakat fitrah, zakat maal, dan menunaikan ibadah haji bersama semua anak kandung, anak menantu juga sudah di umrohkan, karena dipandang terlalu lama menunggu kesempatan berangkat ibadah haji sesuai aturan pemerintah.

Melihat penampilan subyek yang bernama Hadar ini, orang menjadi salah sangka. Postur tubuhnya setinggi $140 \mathrm{~cm}$ dan berat badan antara 47-52 kg hidup tanpa merokok. Suka ikut angkutan umum untuk bepergian mengurus usahanya. Kemanapun dia bepergian, hampir selalu mengenakan baju koko wama cokelat atau putih, lengkap dengan pecis wama hitam, tidak pernah menggunakan kacamata meskipun membaca atau menghitung uang dalam jumlah besar. Ia tidak mengendarai sepeda motor, dia mengaku lupa dan tidak terampil lagi mengemudikan kendaraan roda dua ataupun yang roda empat (4) mengaku sudah terlalu tua. Hadar, panggilan akrabnya, menempuh pendidikan Sekolah Rakyat di Kebumen, sedangkan istri anal Klirong kabupaten yang sarna. Usai menikah, keduanya berangkat transmigrasi tahun 1958-1981 ke Lampung. Sedangkan mendaftar transmigrasi kc Pangkoh adalah transmigrasi yang kedua pada tahun 1982. Ia terlihat merokok sejak menunaikan ibadah Haji. Ibadah Haji bersama keluarga, istri dan anak yang berjumlah 8 orang. Usai ibadah haji yang pertama, mengaku bertambah sehat, berat badan bertambah, merasa lebih ringan jalan pagi bcrsama istri dan beberapa cucu setiap minggu pagi.

Hadar pernah bekerja di perusahan CV Gemor yang menerima kulit kayu hutan, sampai mendapat kepercayaan sebagai pemasok, pernah kena musibah. Penjualan sampai satu (1) ton tenggelam, dan insyaf salat istikharah dan memilih ganti usaha.

Meski berat dengan musibah yang menyebabkan kerugian besar itu, beruntung karena mengaku bahwa dalam hidup ini sebenarnya tidak hidup sendiri, percaya ada yang maha kuasa dan maha kaya. Ia tetap melanjutkan hidup, melanjutkan usaha yang mula-mula dirintis jualan sayur dan buahbuahan ke Palangka Raya pulang-bulik ke Pangkoh. Hadar mendapat amanat dari Haji Cahyono pada akhir tahun 2000 untuk jualan sayur dengan modal "dengkul saya". Hanya bermodalkan kepercayaan dari orang yang baru kenal. Mulai dagang sayur dari kenalan asal kota Batu Malang, sejak awal tahun 2001 saya mendapat beberapa kemudahan 
menjalankan amanah mengelola usaha sayur sampai sekarang.

Tahun 2005 ibadah ke Mekah sekeluarga,bersyukur, mungkin bocah-bocah sudah pada umroh semua. Ada satu orang anak menantu di Pangkoh yang jadi guru agama dan mengurus kebun sayur di tanah dan pemerintah. Semua anak diberikan mobil satu-satu supaya mandiri, kalau sudah bisa mandiri dan berhasil saya kasih modal, timbangan dan peralatan dagang. Pada tahun 2012 Hadar akan menunaikan ibadah Hajji lagi bersama menantu-menantunya, sedangkan anak kandung dan cucunya supaya bergantian antara berangkat ibadah haji dan mengurus usaha.

Saya tidak menyuruh anak-anak berkuliah tinggi-tinggi, jane ya ora bener angger saiki, mbiyen ya pas bae, maka dari itu sebagai penggantinya adalah cucu-cucu saya sekarang disiapkan menabung biaya pendidikan. Cucu yang sekolah MTs Negeri atau swasta dibuatkan buku tabungan persiapan pendidikan dengan isi Rp 50.000.000; soko mbah. Cucu yang mau masuk sekolah Aliyah atau menengah lainya ditambah lagi sebesar Rp 50.000.000, lagi sehingga sedikitnya menjadi punya Rp 100 juta. Itu hadiah tabungan pendidikan dari embah haji untuk persiapan kuliah, sedangkan untuk biaya sekolah sehari-hari tetap biaya dari orang tuanya masingmasing, bukan mengurangi uang itu, biar menjadi beranak-cucu juga di rekening. Ada dua putu yang kuliah, setunggal di Akbid dan setunggal fakultas ekonomi di UNPAR.

Putra yang dipercaya adalah Wahyu Hidayat, 46 tahun sebagai penerusnya tetapi keenam kelihatan sepakat semua, misalnya satu dikasih mandate yang enam juga percaya saja. Hadar sekarang sedang mengembangkan usaha lahan perkebunan kelapa sawit 30-100 hektar, dan direncanakan bisa tambah luas. Usaha sawit di pedalaman Takaras masih wilayah Palangka Raya. Peluang untuk jualan pasar tidak ada habisnya sampai kapanpun tetapi kalau lahan bisa habis untuk pemukiman penduduk atau pembangunana. Saya bina anak-anak buat usaha semoga diberi petunjuk oleh yang maha kaya dan maha kuasa. Modal pokok dan utama adalah kebiasaan jujur, berani menghadapi risiko, dan temen-temen (serious) nyambut gawe .

Omset di Palangka dalam satu (1) bulan ada tiga (3) miliar; ditambah omset di wilayah Banjarmasin, Barabai, Kandangan sudah sama seperti di Palangka Raya yang kira-kira tiga (3) miliar juga. Usaha sayur adalah usaha layanan yang utama tetapi juga tidak menolak bilamana ada muatan buahbuahan, membawa barang bekas atau rongsok serta membawa temak untuk menutup ongkos armada menyebrang ikut di dalam kapal laut.

Pemilihan lembaga pendidikan untuk anak-anak Hadar relevan dengan pendirian yang bersangkutan bahwa tidak diperlukan berkuliah tinggi-tinggi cukup dengan menyelesaikan sekolah menengah seperti SMA, STM, SMEA, dan yang sederajat. Memperhatikan kondisi Hadar yang memiliki enam (6) orang anak hidup di pedesaan yang susah mendapatkan transportasi darat demikian pula transportasi air karena terpencil pada awal dasawarsa pertama, keadaan ekonomi keluarga belum menguat, memiliki penggalaman kerj a keras dengan hasil yang tidak memuaskan di Lampung, latar belakang pendidikan suami istri yang pas-pasan dan lahan pertanian yang susah diolah dibandingkan dengan kesuburan tanah di Jawa. Sarana transportasi penjualan hasil tani di lokasi transmigrasi lamban dan susah. Semua anak jangan sampai lebih susah daripada orang tuanya. Anak dilatih bekerja meniru pekerjaan orang tuanya dan meneruskan usaha yang dirintis orang tuanya. Hadar mengakui keberhasilan ini atas kerjasama dan mendapat ridlo dari yang maha kuasa, oleh karena itu merasa usaha yang dirintisnya harus dilanjutkan karena banyak membawa keberuntungan dan menjadi puncak keberhasilan yang tertinggi dan dikagum oleh warga trans yang lain di tingkat kecamatan. Kebijakan hadar 
relevan dengan kategori atau kateristik orang tua yang instant, seperti disebutkan Agus Wibowo, 2011.

Pada puncak keberhasilan usahanya Hadar mengubah pendirian tentang pendidikan, yang semula tidak menyuruh satupun kepada anaknya untuk berkkuliah, sekarang memotifasi dalam bentuk mendukung dan memodali cucu-cucunya dengan dana yang relatif bes-ar supaya memiliki semangat menempuh sekolah dan kuliah untuk memiliki kesarjanaan sebagai modal awal dalam menjalani kehiduan pada era yang kompetitif atau sarat dengan persaingan.

Hadar menaruh perhatian pada ibadah, menunaikan ibadah haji bersama keluarga secara lengkap. Artinya eman (6) orang anaknya diberi contoh yang langsung untuk melakukan ibadah yang dianggapnya paling bergengsi, karena tidak semua warga trans mampu melaksanakannya ke sana (Makkah). Hadar menetapkan daya cekal yang kuat kepada anak-anaknya dalam bidang iman Islam. Ia punya cara dengan mengajak semua anaknya menunaikan ibadah haji, menantunya semua dibiayai untuk melakukan ibadah umroh. Dilihat dari segi pendidikan cara yang dilakukan Hadar termasuk pendidikan yang langsung dan Hadar berperan sebagai orang tua yang memberi contoh dengan harapan semua anak dan menantu tetap menjadi muslim dan memiliki iman yang relatif kuat.

Dilihat dari segi pilihan ilmu/lembaga pendidikan yang dipilih untuk anak-anaknya memang hampir tidak ada yang menyelesaikan Madrasah atau mengalami proses pendidikan di Pesantren. Kondisi ini relevan dengan keadaan keluarga hadar pada masa itu. Kenyataan Hadar memilih lembaga pendidikan yang dekat dengan keterampilan, rupanya juga mengarahkan anaknya untuk cepat memperoleh pekerjaan yang berkaitan dengan kecakapan hidup seperti STM, SMEA, dan SPP.
Cara Hadar hampir sama dengan impian salah seorang migran muslim yang disamarkan dengan nama Hakarji yang berhasil dalam mengelola usaha, akan tetapi berbeda bidang usaha. Hakarji berhasil dalam bidang jasa layanan pengadaan ternak dan jas transportasi angkutan barang. Kedua pengusaha jasa ini berbeda visinya terhadap pendidikan, jika Hadar mencegah, tetapi Hakarji meminta pendapat putra — putrinya. Anak boleh menempuh pendidikan setingitingginya asalkan bertanggung jawab, harus pulang membawa ijasah. Hal ini menjadi kenyataan, pada anak pertama, sebagai mana diceritakan Hakarji berikut ini:

Anak pertama, Sunarto, 27 tahun. Menyelesaikan pendidikan SD, MTs, MAN., STAIN. Guru MAN Maliku. Narto menikah dengan Nuryulita yang lahir tahun 1983, pendidikannya SD, SMP, MA dan S-1 Tarbiyah STAI Kapuas. Bekerja sebagai Guru honorer mata pelajaran al-Qur'an Hadits di MAN Maliku, status dalam proses pemberkasan CPNS. Memiliki seorang anak perempuan bernama Faizah Sa'adi yang berusia 11 bulan. Kedua, Nyarminati, 20 tahun. Menyelesaikan pendidikan SD., MTs., SMA, Pesantren Darul Hijrah Banjarmasin. D3 kebidanan STIKES. Ketiga, Ahmad Wahyudi, 18 tahun. Menyelesaikan pendidikan SD., MTs. Darul Hijrah, SMA Darul Hijrah.

Hakarji, 54 tahun lahir di Nganjuk Jawa Timur, demikian pula Suminten yang lahir pada tahun 1961. Pendidikan yang diselesaikannya adalah sekolah dasar (SD) sedangkan istrinya hanya sampai kelas V SD karena dinikahkan. Keduanya tiba di Pangkoh pada tahun 1981didanai pemerintah. Keduanya bekerja sebagai pedagang ternak kecil — kecilan termasuk ayam dan kambing Kemudian ditingkatkan menjadi pengusaha ternak sapi dan jasa transportasi jasa angkutan barang dan hewan, bahan-bahan bangunan seperti pasir, tanah uruk, dan ternak.

Pembelian ternak dilakukan dengan 
cara tidak membayar secara langsung akan tetapi menetapkan kesepakatan atau janji jadi lebih dahulu dengan pembayaran pada waktu tahun ajaran baru anak masuk sekolah, kuliah atau pada menjelang hari raya lebaran. Di lingkungan tempat tinggal Hakarji, sekitar 100 meter telah dibangun Masjid Baiturrahman yang sebagian besar dana berasal dari Hakarji, akan tetapi pemanfaatannya untuk lingkungan sekitarnya atau untuk umum.

Ia menjual ternak di dua wilayah yaitu wilayah Banjarmasin dan Palangka Raya. Penjualan ke Palangka Raya cukup dikirim dua (2) bulan sekali antara $10-15$ ekor sapi, sedangkan penjualan ke Banjarmasin dilakukan sebulan dua kali dengan jumlah sapi antara 15 - 20 ekor sapi, untuk kepentingan usaha itu, lancar tanpa kendala karena tersedia tiga orang supir tetap selain ada dua (2) orang supir cadangan, armada relatif baru dan para karyawan baik-baik, jujur, suka kerj a, dan bertanggungjawab dengan tugasnya.

Dikaji dari spirit menempuh pendidikan anak yang berpendidikan tampak nyata. Keluarga ini memilihkan dan memberi kepercayaan kepada lembaga pendidikan agama kepada semua anak, artinya dan anak pertama sampai ketiga menempuh pendidikan madrasah, baik yang sekaligus pesantren ataupun madrasah berstatus negeri. Pembelajaran di madrasah, meskipun belum terjamin, akan tetapi sekurangnya pembelaran agama Islam terletak dalam lingkungan Islam, sehingga memungkinkan anak-anak ini berteman dengan sesama muslim, bertemu dan berinteraksi dengan guru-guru agama dan guru mata pelajaran umum yang juga muslim. Tidak memungkiri, bahwa madrasah negeri menyelenggarakan pembelajaran ilmu umum dengan persentase lebih besar.

Keluarga Hakarji mempercayakan anaknya pada usia antara 13- 15 tahun masuk ke dalam lingkungan madrasah. Mengarahkan anak berteman dengan sesama iman, berpakaian Islarni, bercakap santun, menyediakan kesempatan shalat berjamaah, membiasakan membaca al-Qur'an pada awal kegiatan kelas. Hal ini relevan dengan pentingnya interaksi, lingkungan pergaulan, dan pembiasaan yang banyak ditulis dalam referensi, dan dibicarakan dalam forum ilmiah.

Hakarji dengan caranya sendiri seperti disebut sebelumnya adalah relevan dengan apa yang disebut orang tua tipe instan, oleh Agus Wibowo, 2011. Lain halnya dengan impian Bukus 49 tahun yang punya usaha rumah makan Pecel Jawi, pandai bersyukur dan selalu memotivasi anaknya supaya memiliki etos kerja tinggi, berkarakter, dan mengemban amanah atau tugas sebagai abdi Negara didinas perusahaan listrik Negara (PLN) Palangka Raya. Lebih lanjut Bukus menuturkan sebagai berikut:

Anaknya bernama Rudianto, 30 tahun menyelesaikan pendidikan SD, SMP, STM listrik. Rudianto bekerja sebagai PNS di PLN cabang Palangka Raya. Menikah dengan Suparti lulusan MAN, bekerja bersama mertua mengelola rumah makan khas masakan pecel jawa di jalan Rinjani. Keluarga Rudianto

Memiliki 2 orang putra, yang pertama kelas VI SD dan yang kedua kelas IV SD. Istri mendampingi ibu mertua mengelola usaha di Rumah Makan Pecel Jawi, dibantu ayah mertua dan dua karyawan yang masih hubungan family dari Kebumen.

Datang di Pangkoh Kalimantan tahun 1981 di Pangkoh IV, tahun 1985 bapak kulo pak Cola() Winoto kulo pendet lan kulo purugi mriko wonten Jawi, lajeng bapak kerja dijadikan mekarsari/ajudannya pak wali kota ngantos gangsal tahun. Salajengipun, ayah ditugasi ketua keamanan Pasar Kahayan sambil mbah cokro menjual sayur yang diambil dari lokasi trans Pangkoh. Diberi rumah dinas ukuran 8 X 6 m2 oleh pak wali kota.

Menurut ukuran besar-kecilnya 
kebutuhan konsumsi keluarga Bukus bisa dikatan relatif, demikian pula biaya pendidikan pada sekolah menengah dan perguruan tinggi dalam kota dan daerah Kalimantan Tengah. Keluarga ini memulai usaha tani di pemukiman transmigrasi. Bukus berulang-kali ke kota Palangka Raya membantu pekerjaan orang tuanya yang membuka jasa rumah Makan Peeel Jawi yang ramai pengunjung dan nyaris tanpa pesaing, ketika itu pendapatan perhari mencapai 4.5 - 5 juta Rupiah. Kondisi usaha ini mengalami penurunan pemasukan sesudah mbah Cokro meninggal karena sepuh, dalam usia 85 tahun.

Usaha dilanjutkan Kusniani dan memindah tempat usahanya, sekitar 500 meter ke arah Barat, mengikuti aturan pemda kota, di mana semua usaha non-ruko bertingkat hams keluar dari kompleks bangunan pasar yang sejak tahun 2010 menjadi pasar modern, kompleks pertokoan bebas dari bangunan milik perorangan.

Rumah Makan Bukus sudah sering menjadi langganan makan siang bagi banyak warga Palangka Raya, sehingga yang sering mengajak kawan kerja lembur menikmati masakan nasi-pecel ini. Posisi Rumah makan ini masih dalam kota, lingkungan pasar modern Kahayan, atau $1,5 \mathrm{~km}$ dan kantor Pemda Provinsi arah kantor Pemda Kota Palangka Raya. Rumah asal pemberian dari kanwil transmigrasi masih ada di Pangkoh masih tetap dilestarikan untuk dikunjungi dan menyelenggarakan .acara syukuran, tasmiyahan keluarga, Ary san bersama warga masyarakat Pangkoh IV. Di rumahnya bukan untuk mengerjakan usaha atau dagang tetapi kepentingan silaturrahim dan istirahat satu sampai dua hari ketika liburan atau acara khajatan. Kulo asale orang tidak punya dan hidup susah di Pangkoh. Di Pangkoh kulo gadah sawah dua (2) hektar dan memelihara 2 sapi serta 6 kambing.

Ibu saya tidak ada yang membantu, maka saya ikut kerja orang tua di rumah makan pecel jawa seperti masak nasi, cuci piring dan lairs-lain. Saya, dirumah beserta suami dan satu orang anak laki-laki namanya rudianto tamatan STM jurusan listrik dan kerja di dinas PLN, Palangka Raya ditambah punya menantu dan dua cucu.

Dahulu kontrak 3 tahun, sekarang sudah menjadi hak milik sendiri harga $\mathrm{Rp}$. 400 juta dibayar kontan. Saya merasa syukur sanget, sampun berhasil bisa beli mobil Daihatshu, padahal dulu rumahnya kecil. Saya juga sudah mbantu keluarga dari Kebumen tetapi belum seluruhya karena berjumblah sepuluh, meskipun bare bisa enam orang.

Mulai membuka usaha waning adalah jam gangsal sudah buka, tutup usaha ini adalah jam sekawan. Usaha meniko mboten wonten libur amargi ingkang kerjo kalebet keluargi jumlahe yoga tigo, ingkang kakung kaleh denten ingkang setri setunggal.

Tanah yang diberi pemerintah masih ada, digarap oleh keluraga karena saya menyuruhnya dan paling saya hanya membayar pajaknya dan hasilnya biarlah keluarga yang mengambil asalkan dirawat tanahnya. Pekarangan ada seperampat hektar ditanami pohon kelapa, cempedak dan dipelihara keluarga di Pangkoh.

Bukus, Hakarji dan Hadar ketiganya termasuk migran yang berhasil di bidang jasa, tetapi masing-masing punya cara pandang berbeda terhadap pendidikan, akan tetapi perhatian kepada sanak kerabat dan ibadah serta bersyukur hampir sama kuat.

(2) Anak sebagai amanah yang mengayomi di masa tua

Hampir bertolak belakang dengan cara pandang salah seorang petani yang punya keluarga besar. Wagimin, 72 tahun asal Kebumen. Pendidikan SR bekerja sebagai petani dan pemelihara ternak sapi. Dibantu istrinya Waginah 68 tahun asal Kebumen menyelesaikan Sekolah Rakyat di daerahnya. Memiliki enam (6) orang anak. Selanjutnya Wagimin menceritakan putra- 
putrinya yang haus pendidikan sebagai berikut:

Anak pertama, Paryo, 49 tahun. Menlelesaikan pendidikan SD, SMP, SMA, D2 Tarbiyah, D3 Tarbiyah, Si Tarbiyah dan S2 MPI UNISMA. Bekerja sebagai guru/kepala MAN Maliku. Golongan IV/a status sertifikasi diperoleh pada tahun 2009. Menikah dengan Dwi Yuniarti SPdI lulusan Tarbiyah bekerja sebagai kepala desa Pangkoh VI. memiliki 3 orang anak yaitu Mukhlis kelas 3 SMP, Muklas kelas 2 SD, dan Andika Nogroho usia 2 tahun. Kedua Siti Halimah, 47 tahun. Menyelesai kan pendidikan SD, MTs, SMA, Tarbiyah STAIN, bekerja sebagai guru MTsN. Ketiga, Lestari, 45 tahun. Menlelesai-kan pendidikan SD, MTs, SMA, STIE Si ekonomi, bekerja sebagai wiraswasta. Mengikuti suami yang menjadi PNS di dinas industri dan perdagangan. Keempat, Fitriani, 41 tahun. Menyelesaikan pendidikan SD, MTs, SMA, Matematika FKIP UNPAR bekerja sebagai guru SMPN. Kelima Taufikur-rahman, 40 tahun. Menyelesaikan pendidikan SD, MTs, SMA bekerja sebagai polisi di Buntok.

Wagimin mempercayakan kepada madrasah sebagai tempat bcrsekolah anakanaknya belajar agama dari anak pertama sampai yang kclima. Belajar di madrasah dimulai pada usia anak remaja, tingkatan pendidikan madrsah tsanawiyah dan madrasah aliyah. Pada pendidikan awal semuanya mempercayai sekolah dasar untuk semua anak karena di lokasi transmigran tidak tersedia madrasah ibtidaiyah negeri maupun swasta dari tahun 1982-2009, padahal mayoritas orang migran yang berdomisili di Pangkoh memeluk agama Islam. Pendidikan tinggi yang dipilih oleh anak-anak Wagimin dua orang sarjana pendidikan agama. Waginin dan Waginah hanya sempat menyelesaikan pendidikan setara pendidikan dasar, namun semua anaknya lebih dari pendidikan menengah atas bahkan empat (4) orang dari lima (5) anaknya meraih impian sarjana S.1., lebih dari itu anak pertama menyelesaikan program Magister Pendidikan Islam dan sedang menjabat kepala Madrasah Aliyah Negeri (MAN) dengan golongan IV/A, telah bersetifikat dan menerima tunjangan sertifikasi guru.

Dilihat dari sisi agama, Supar dan istri termasuk orang yang suka ibadah meskipun yang dilakukan secara berjamaah rata-rata hanya tiga waktu, Magrib, Isya dan Subuh. Tura termasuk contoh yang membangkitkan semangat melanjutkan kuliah kepada kakaknya yang hampir kadaluarsa, adiknya, Hartini dengan gigih dan hidup sederhana artinya berjalan kaki pulang pergi kegiatan ke kampus dan hidup bergabung membantu keluarga orang, tetapi juga tidak mau ketinggalan di bidang pendidikan.

Dan segi sosiologi, seorang mahasiswi yang hidup bergabung dengan keluarga yang diikutinya yang kebetulan adalah keluarga berpendidikan tinggi dan bekerja sebagai PNS dalam waktu yang lama, terns menerus, rutin dan bcrulang kali dapat menimbulkan dampak positif terhadap pemikiran dan cita-cita untuk mampu menycicsaikan pendidikan sarjana dan bekerja. Dengan bckerja keluarga menjadi lingkungan yang kondusif bagi Hartini karena beberapa kebiasaan dalam keluarga yang diikuti bisa diamati, didegarkan, dan dilihat dalam bentuk perilaku orang-orang yang berhasil. Menurut Mulyasa pembiasaan dan melihat contoh teladan dari orang dekat adalah salah satu dari cara menanarnkan karakter ke dalam aktifitas sehari-hari (Mulasa 2011, hlm. 165-170). Lebih lanjut Mulyasa menyatakan bahwa kegiatan pembiasaan yang tidak terprogram tetapi dilaksanakan secara rutin, secara spontan termasuk penanaman karakter yang dilakukan secara informal.

(3) Modal ngelmu kanggo saumure Mustofa, 65 tahun lahir di Ambarawa Kabupaten Semarang Jawa Tengah, tiba di Pangkoh tahun 1982 biaya perjalanan ditanggung oleh pemerintah. Ia 
menikah dengan Nurhasanah, 60 tahun berasal - dari tetangga di desanya. Pendidikan pasangan ini adalah sekolah rakyat sama dengan isterinya. Mustafa bekerja sebagai petani, tukang mebeler dan memelihara ternak sapi. Isterinya sebagai ibu rumah tangga dan membantu pekerjaan di ladang serta memelihara ternak. Memiliki seorang anak yaitu anak pertama bernama Dono.

Mustofa memilihkan pendidikan untuk anak-anak remajanya pada pendidikan umum, akan tetapi pada pendidikan sarjana yang memilih pendidikan agama sebanyak tiga orang pada anak pertama sampai ketiga, sedangkan anak keempat dan kelima memilih pendidikan umum yang dipadukan dengan kurikulum agama yang diselenggarakan di STAIN. Etos pendidikannya dapat dikategorikan tinggi, mereka menyelesaikan S.1 meski semuanya bekerja part time selama menempuh kuliah.

Pekerjaan anak-anaknya bervariasi, bagi yang laki-laki bekerja dengan mengambil upah pada pekerjaan bangunan, jasa pengetikan, memperbaiki rumah di mana Ia menempuh pendidikan. Seperti yang dilakukan oleh Dono, sudah menjadi PNS dan mendapat status sertifikasi. Secara fisik rumah tangga Dono tergolong maju dengan pesat karena telah memiliki rumah sendiri yang permanen dan bagus dengan posisi yang strategis dan terbaik di lingkungan Perumahan Carita Permai jalan G. Obos IX. Istrinya juga PNS guru baru menyelesaikan pendidikan sarjana S.1 Tarbiyah.

Menurut konsep Islam, Dono termasuk kepala keluarga yang memiliki tanggungjawab tinggi, semua anaknya dimotivasi untuk menjadi sarjana, dilatihnya untuk ikut bertanggungjawab terhadap keperluan dana pendidikan. Semua anaknya tidak ada yang terlibat perilaku yang mengakibatkan citra kurang baik. Mustofa suka kerja keras dan menjaga nama baik keluarga, bekerja sebagai tukang mebeler atau kerajinan mebelair dan memborong perbaikan/rehab rumah sampai ke provinsi tetangga, Banjarmasin dan sekitarnya karena memperoleh order melalui informasi dari mulut ke mulut khususnya karena kwalitas kerja yang memuaskan pelanggan.

Menurut konesp Islam Mustofa termasuk keluarga yang berhasil, bukan hanya berhasil mendukung pendidikan anaknya akan tetapi menjaga keutuhan rumah tangga dan anaknya menjadi sarjana. Menurut sudut pandang pendidikan Musfota dan anak-anaknya secara kualitas meningkat, di mana kedua orang tuanya hanya menamatkan sekolah dasar, kondisi ekonomi yang pas-pasan, akan tetapi terjalin kekompakan antara orang tua dan anak untuk menjalankan tanggungjawabnya masing-masing, anak ikut menanggung biaya pendidikan dengan mengisi waktunya dengan kesibukan kerja dan ayahnya keraja keras untuk mendapatkan dana pendukung pendidikan dan memenuhi keperluan dasar rumah tangganya, istrtinya berada di tempat dengan memelihara ternak sapinya dan beberapa kapling tanah pertanian.

\section{Pembahasan: Tumbuhnya Etos Pendidikan pada Keluarga Migran Muslim.}

Observasi yang dilakukan penyusun memperoleh informasi bahwa para transmigran muslim Pangkoh sudah banyak memahami ayat-ayat atau ajran Islam yang berkenaan dengan hijrah atau berpindah. Walaupun mereka tidak hafal, tetapi pemahaman tentang hal ini nampak jelas. Misalnya ayat berikut ini:

"Sesungguhnya orang-orang yang beriman dan berhijrah serta berjihad dengan harta dan jiwanya pada jalan Allah dan orang-orang yang memberikan tempat kediaman dan pertolongan (kepada orangorang muhajirin), mereka itu satu sama lain lindung-melindungi. Dan (terhadap) orangorang yang beriman, tetapi belum berhijrah, maka tidak ada kewajiban sedikitpun atasmu 
melindungi mereka, sebelum mereka berhijrah. (Akan tetapi) jika mereka meminta pertolongan kepadamu dalam (urusan pembelaan) agama, maka kamu wajib memberikan pertolongan kecuali terhadap kaum yang telah ada perjanjian antara kamu dengan mereka. Dan Allah Maha Melihat apa yang kamu kerjakan. Dan orang-orang yang beriman dan berhijrah serta berjihad pada jalan Allah, dan orangorang yang membcri tcmpat kediaman dan memberi pertolongan (kepada orang-orang muhajirin), mereka itulah orang-orang yang benar-benar beriman. Mereka memperoleh ampunan dan rezki (nikmat) yang mulia. Dan orang-orang yang beriman sesudah itu kemudian berhijrah serta berjihad bersamamu maka orang-orang itu termasuk golonganmu (juga). Orang-orang yang mempunyai hubungan kerabat itu sebagiannya lebih berhak terhadap sesamanya (daripada yang bukan kerabat) di dalam kitab Allah.

Sesungguhnya Allah Maha Mengetahui segala sesuatu". (al-Anfal: 7275). Ayat-ayat ini merupakan rangkaian ayat-ayat tentang pindah atau hijrah yang paling lengkap dan tersusun secara berurutan dari sekitar dua puluh ayat yang berbicara tentang hijrah. Karena ayat hijrah yang lain tersebar di beberapa tempat secara terpisah dan berdiri sendiri.

Dalam konteks hijrah, ditampilkan dua kelompok manusia yang sama-sama secara berdampingan mendapat penghargaan dan tempat istimewa di sisi Allah atas ketulusan pengorbanan dan pengabdian mereka. Dua kelompok tersebut diabadikan dengan istilah yang indah dalam al-Qur'an, yaitu Muhajirin dan Anshar. Muhajirin adalah orang-orang yang dengan suka rela meninggalkan semua yang mereka miliki beserta tanah air tempat tinggal mereka demi menyambut seruan Allah dan Rasul-Nya. Sedangkan kelompok Anshar adalah mereka yang siap mencrima, membela, memberi perlindungan dan bantuan kepada orangorang yang berhijrah dengan tanpa mengharapkan imbalan selain balasan pahala dari Allah swt.

Kedua kelompok manusia ini diabadikan oleh Allah dalam al-Qur'an dengan penghargaan dan jaminan yang tertinggi; Ridho Allah dan syurga-Nya yang abadi. Allah berfirman:

"Orang-orang yang terdahulu lagi yang pertama-tama (masuk Islam) dari golongan Muhajirin dan Anshar dan orangorang yang mengikuti mereka dengan baik, Allah ridha kepada mereka dan merekapun ridha kepada Allah dan Allah menyediakan bagi mereka surga-surga yang mengalir sungai-sungai di dalamnya selama-lamanya. Mereka kekal di dalamnya. Itulah kemenangan yang besar". (At-Taubah: 100).

Ayat dengan redaksi yang sama dengan ayat ini berulang di surat At-taubah: 117, An-Nur: 22, Al-Ahzab: 6, dan AlHasyr: 8 Yang menarik untuk dicermati dari ayat yang menyebut aktor pelaku hijrah bahwa selain dari kelompok Muhajirin dan Anshar, Allah masih membuka peluang jaminan dan penghargaan yang sama dengan mereka bagi siapapun yang mampu mengikuti jejak teladan kedua kelompok itu dengan baik pasca hijrah yang tersirat dari firmanNya: "dan orang-orang yang mengikuti mereka (Muhajirin dan Anshar) dengan baik, Allah ridha kepada mereka dan merekapun ridha kepada Allah dan Allah menyediakan bagi mereka surga-surga yang mengalir sungai-sungai di dalamnya selamalamanya. Mereka kekal di dalamnya. Itulah kemenangan yang besar". Demikian gambaran hijrah Rasul dengan para sahabatnya dalam konteks sejarah ayat di atas ternyata sarat dengan nilai perjuangan, pengorbanan, kepeduliaan terhadap sesama, kesabaran dan persaudaraan (ukhuwah) yang melebihi batas kekeluargaan dan kekerabatan karena direkat dengan ikatan akidah. Nilai luhur ini merupakan nilai universal yang berlaku sepanjang zaman pasca sabda Rasulullah saw tentang hijrah: "Tidak ada hijrah setelah pembebasan kota Mekah, tetapi jihad dan niat". (H.R. 
Bukhari). Justru ujian nilai hijrah akan tetap menjadi neraca ketulusan dan kualitas iman seseorang dengan sebuah jaminan bahwa hijrah yang diperintahkan Allah tidak ada lain adalah untuk kebaikan dan kemaslahatan bersama. Allah berfirman menjelaskan $\mathrm{j}$ aminan-Nya:

"Barangsiapa berhijrah di jalan Allah, niscaya mereka mendapati di muka bumi ini tempat hijrah yang luas dan rezki yang banyak. Barangsiapa keluar dari rumahnya dengan maksud berhijrah kepada Allah dan Rasul-Nya, kemudian kematian men i mpanya (sebelum sampai ke tempat yang dituju), maka sungguh telah tetap pahalanya di sisi Allah. Dan adalah Allah Maha Pengampun lagi Maha Penyayang". (An-Nisa': 100).

Sungguh begitu mempesona Fragmen kehidupan dan interaksi harmonis yang tercermin antara orang-orang Muhajirin dan Anshar dalam konteks AlItsar (mengutamakan dan lebih mementingkan saudaranya meskipun is sangat membutuhkan) yang merupakan tahapan tertinggi dari sebuah implementasi bangunan ukhuwah (persaudaraan) yang telah ditunjukkan dalam sejarah hijrah sahabat Rasulullah:

"Dan orang-orang yang telah menempati kota Madinah dan telah beriman (Anshar) sebelum (kedatangan) mereka (Muhajirin), mereka (Anshar) 'mencintaf orang yang berhijrah kepada mereka (Muhajirin). Dan mereka (Anshar) tiada menaruh keinginan dalam hati mereka terhadap apa-apa yang diberikan kepada mereka (Muhajirin); dan mereka mengutamakan (orang-orang Muhajirin), atas diri mereka sendiri, sekalipun mereka dalam kesusahan. Dan siapa yang dipelihara dari kekikiran dirinya, mereka itulah orang orang yang beruntung".(A/-Hasyr: 9).

Pembacaan lain dari ayat-ayat hijrah, bahwa aktifitas hijrah tidak terlepas dan selalu diapit dengan iman sebagai pondasi dan perjuangan (jihad) sebagai nilai aplikatif dari hijrah. Pendampingan dan pengapitan hijrah dengan iman dan jihad di dalam al-Qur'an tentu bukan sebatas memenuhi standar keindahan bahasa alQur'an, tetapi lebih dari itu terdapat nilai dan hikmah yang dikehendaki oleh Allah agar kita senantiasa memaknainya; bahwa hijrah memang merupakan bukti ketulusan iman seseorang, sedangkan jihad merupakan buah sekaligus konsekuensi logis dari aktifitas hijrah. Iman tanpa hijrah tidak akan bermakna, begitupula hijrah tanpa jihad berarti tidak berbuah. Makanya pendampingan ini berulang sebanyak sembilan kali, diawali dengan surat alBaqarah: 218 yang berbunyi:

"Sesungguhnya orang-orang yang beriman, orang-orang yang berhijrah dan berjihad di jalan Allah, mereka itu mengharapkan rahmat Allah, dan Allah Maha Pengampun lagi Maha Penyayang. Sesungguhnya orang-orang yang beriman, orang-orang yang berhijrah dan berjihad di jalan Allah, mereka itu mengharapkan rahmat Allah, dan Allah Maha Pengampun lagi Maha Penyayang". Kemudian disusul secara berurutan dengan surat Ali Imran: 195, Al-Anfal; 72-75, At-Taubah: 20, AnNahl: 41 dan 110, serta surat Al-Hajj: 58.

Semua ayat yang berbicara tentang hijrah di atas adalah dalam konteks hijrah makaniyah (hijrah fisik; perpindahan dari suatu tempat ke tempat yang lain) untuk mempertahankan akidah. Terdapat hanya satu ayat yang berbicara dalam konteks hijrah ma'nawiyah (hijrah nilai; berubah dari satu keadaan menuju keadaan yang lebih baik), yaitu firman Allah swt:

"Maka Luth membenarkan (kenabian)nya. Dan berkatalah Ibrahim: "Sesungguhnya aku senantiasa berhijrah kepada Tuhanku; sesungguhnya Dialah Yang Maha Perkasa lagi Maha Bijaksana". (al-Ankabut: 26). Dan di antara yang harus ditinggalkan dalam konteks hijrah maknawiyah seperti yang pernah Allah perintahkan kepada Rasulullah di era awal 
turunnya al-Qur'an adalah perbuatan dosa dan maksiat seperti yang disebutkan dalam surat al-Muddatsir: 5 yang bermaksud: "Dan perbuatan dosa tinggalkanlah".

Memang hijrah makaniyah sangat kondisional dan mungkin tidak akan berulang seperti yang pernah terjadi di era Rasul, tetapi nilai dan pelajaran hijrah makaniyah masih tetap relevan, yaitu pelajaran kesabaran, kesiapan berkorban dan berjuang, kepeduliaan terhadap sesama, pelajaran persaudaraan yang dibangun atas dasar iman dengan itsar sebagai peringkat yang tertinggi serta pelajaran ta'awun untuk memperkuat posisi Islam dan umatnya. Kehidupan sosial yang ideal dan harmonis justru dirasakan oleh para sahabat saat peristiwa hijrah berlangsung. Sungguh betapa bernilai memang pelajaran hijrah para sahabat Rasul sehingga layak dijadikan momentum untuk melakukan perubahan dan perbaikan arah yang lebih baik, baik dalam skala pribadi, keluarga dan sosial. Ditambah dengan hijrah ma'nawiyah yang merupakan media komunikasi dan harmonisasi hubungan dengan sang Khaliq.

Menggaris bawahi tentang adanya peluang untuk melakukan hijrah sebagaimana orang muhajirin adalah transmigran yang memiliki semangat keislaman dan untuk mempetahankan Islam mereka. Masjid-masjid dan kelompok pengajian di Pangkoh menunjukkan hal itu.

$$
\text { Melihat keluarga transmigran }
$$

Pangkoh yang diobservasi aktif dalam bidang keagamaan atau agama Islam, maka dapat diduga pengaruh aktivitas keagamaan mempengaruhi etos pendidikan mereka secara positif. Aktivitas keagamaan yang salah satunya berupa pengajian, biasanya tidak meninggalkan dalil untuk bekerja keras dan berpendidikan atau menuntut ilmu. Sebagaimana firman Allah: dan jika dikatakan kepada kamu semua berlapanglah kamu maka melapangkanlah kamu, allah mengangkat mereka yang beriman dari kamu dan diberi ilmu beberapa derajat. (surat al Hujurat). Penting pendidikan dalam
Islam pun dapat dilihat dari kisah-kisah popular dalam al Qur'an. Misalnya kisah nabi-nabi. Sejak nabi Adam, Yusuf dan nabi Musa bersama Khidr hingga nabi Muhammad s a w, kata-kata ilmu dan pendidikan tidak pernah hilang dalam percaturan pembicaraan mereka.

Mengenai Nabi Adam Allah dalam awal pembicaraannya pada surat al-Bagarah menjelaskan bahwa Ia mengajarkan namanama kepada Adam. Pengajaran Adam tentang seluruh nama-nama dan kemampuannya menyebut kembali merupakan kelebihan. Anak turun Adam yang memahami nama-nama dan kemudian menganalisis dan mensintesiskan akan mampu membuat temuan-temuan baru. Misalnya di daerah Pangkoh, para transmigran yang sudah memahami jenis jenis tanaman dan hewan hewan yang ada di daerah asal, kemudian ia menemukannya di Pangkoh, maka dengan mudah ia akan melakukan sintesis dan analisis. Melihat babi is akan memahami bahwa sesuai ajarannya yaitu agama Islam, babi adalah binatang haram. Maka ia akan menjauhi. Binatang-binatang yang baru dilihat atau jenis tanaman yang barn dilihat di daerah Pangkoh, ia akan melakukan analisis dan pengambilan kesimpulan mana jenis hewan yang baik dan tanaman yang berbahaya untuk dimakan tetapi dapat beinianfaat untuk karya lainnya. Islam memandang hal ini sebagai suatu ijtihad. Rasulullah memberi nilai ijtihad yang benar dengan dua pahala dan ijtihad salah dengan satu pahala, terutama bila situasi memang harus membuat individu berijtihad, sebagaimana transmigran Pangkoh yang memang baru menempati daerah daerah yang belum mereka kenal.

Keija keras nampaknya terlihat pada para transmigran di daerah Pangkoh. Menurut al-Qur'an yang paling tidak menjadi bacaan dan bahan ajar subyek penelitian di Pangkoh kerja keras memang harus dilakukan. Sahabat-sahabat nabi Muhammad digambarkan sebagai kuda yang 
hebat di siang hari, dan pada waktu malam sebagai pendeta yang taat beribadah. Allah berfirman: mereka berjihad dengan harta dan diri mereka. Berpindah untuk menyelamatkan agama dan diri merupakan perjuangan yang diperintahkan nabi Muhammad. Beliau bersabda; berpindahlah maka akan anak anakmu akan mulia. AlQur'an juga menyebutkan: Wahai keluarga Dawud, bekerjalah kamu untuk mewujudkan rasa syukurmu. Firman Allah yang lain dan bekerjalah dengan melakukan karya yang baik. Bekerjalah pekerjaan yang baik, sungguh saya dengan perbuatanmu melihat.

Para penyampai ajaran agama seperti Hasyim nampaknya juga ikut membakar semangat transmigran lewat pengajian yang diadakan di rumahnya. Pengajian-pengajian yang ada di daerah transmigran umumnya member nasihat tentang kesabaran, teguh pendirian, ridlo dengan apa yang telah allahn berikan.

Hubungan keluarga yang penuh harapan dari orang tua sebagaimana tercermin dari keluarga Supar. Supar yang berpendidikan dasar Nampak memiliki semangat besar untuk memperoleh anak dengan pendidikan yang baik. Ungkapan kata-kata yang penuh harap dan cemas bahwa anak itu nasibnya tidak selalu sama. Kadang mereka memiliki harta yang cukup tetapi belum tentu akan berhasil. Ungkapan ini mencerminkan firman Allah: bahwa jika Allah menghendaki kebaikan pada seseorang maka tidak ada yang akan mampu menahannya, dan sebaliknya. Juga perilaku Supar dan hablumminallah searah dengan apa yang termaktub dalam al-Qur'an: Mereka berdoa dengan penuh harap dan cemas.

Supar ternyata menuai hasil. Putrinya Tura walaupun hams bekerja keras ternyata termasuk anak yang cukup berhasil. Dua saudaranya pun nampaknya menapak searah dengan Tura. Langkah Supar untuk mendahulukan pendidikan agama merupakan langkah tepat dan sesuai dengan ajaran agama yang dianutnya. Nabi Muhammad saw bersabda: menuntut ilmu agama adalah wajib. Allah berfirman: wahai orang orang yang beriman jika dikatakan pada kamu berlapanglah dalam majlis maka merapatlah dan jika dikatakan merapatlah merapatlah, Allah mengangkat orang yang beriman dan diberi ilmu derajat.

(surat al-Hujurat), Hadis nabi Muhammad menjelaskan bahwa siapa yang berusaha meraih akhirat maka is akan memperolah duna dan akhirat. Supar nampak mengutamakan dan mendahulukan urusan putra putrinya terbukti dengan masuknya mereka ke pesantren. Para pakar psikologi positif sering menunjukkan bahwa keberagamaan yang searah dengan ajaran Islam memang dapat membuat sejahtera individu.

Misalnya Akhter pernah mengungkapkan dalam bukunya bahwa kepercayaan pada hari akhir dan adanya surga neraka membuat individu lebih tentram dan bahagia. Sehingga dalam bekerja mereka menunjukkan kepasrahan dan ketekunan sebagaimana yang dapat dilihat dalam keluarga Supar.

Berbeda dengan keluarga Supar, keluarga santamin yang petani membutuhkan dukungan dalam usaha kepala keluarga. Ia meminta putra putri para menantu untuk bergotong royong membantu meringankan hidup seluruh keluarga dengan bertani. Bekerja ternyata merupakan salah satu kunci menuju hidup sejahtera. Walaupun dengan pengetahuan terbatas. Keluarga ini ternyata juga memiliki cita-cita memasukkan putra-putrinya ke sekolah atau perguruan tinggi. Terbukti dengan dua anggota keluarganya yang berhasil menyelesaikan di perguruan tinggi, bahkan sampai jenjang S2, dan sekarang menjabat dekan di perguruan tinggi swasta. Aktivitas keluarga yang menunjukkan kesungguhan dalam berkarya dan belajar tentu saja tidak luput dari agama yang dianut yang selalu mendorong pemeluknya untuk selalu belajar, 
beramal baik dalam urusan dunia maupun akhirat. Bekerj a dengan pekerjaan yang halal seperti bertani ini dalam al-Qur'an dapat ditemukan dalam ayat yang berbunyi: wahai keluarga Dawud, bekerjalah kamu sebagai rasa syukur kamu, sedikit dari hamba-hambaku yang bersyukur.

Penelitian psikologi hampir memastikan bahwa bekerja dengan jujur dan benar dapat meningkatkan kesejahteraan psikologi maupun psiologis. keuntungan lain dari keluarga ini dan yang juga menimbulkan rasa sejahtera dan kebebasan mereka adalah menjadi bos untuk diri sendiri dan tidak diperintah orang lain (being your own boss)

Pendidikan dipandang perlu oleh mereka yang berasal dari pendidikan dasar dan menengah, karena memang dapat dilihat bahwa untuk menjangkau kehidupan yang lebih sejahtera perlu pendidikan.I27 Secara agama Islampun pendidikan akan membawa kesejahteraan dunia dan akhirat sebagaimana dapat dibaca dalam ungkapan berikut: Barangsiapa yang meninginkan dunia maka hendaknya dengan ilmu

pengetahuan; barangsiapa yang menghendaki akhirat maka hendaknya dengan ilmu pengetahuan; dan barangsiapa yang menghendaki keduanya maka hendaknya dengan pengetahuan.

Tolabul 'ilmi atau menuntut ilmu rupanya sudah menjadi pembicaraan dan cita-cita para mingran di Pangkoh. Terbukti banyaknya pengajian yang merupakan ajang nasehat, ajang menyebarkan etos pendidikan dan tentu saja tumpuan dukungan social. Nampak sekali perwujudan sabda nabi Muhammad saw bahwa ummat Islam itu bagaikan bangunan yang satu mendukung yang lain. Ungkapan ini banyak mendapat dukungan dari berbagai penelitian psikologi, terutama psikologi yang berkecimpung di bidang kesejahteraan. Misalnya banyak penelitian psikologi yang dilakukan di daerah yang relative sering dianggap miskin atau sebagaimana terlihat di daerah transmigran mencerminkan hal itu.
Melihat keluarga migrant lebih mengerucut akan ditemukan bahwa dukungan keluarga (family support) juga merupakan tumbuhnya etos pendidikan di kalangan mereka. Family support yang dalam agama Islam sering dikaitkan dengan silaturrohim memang dapat memperluas rizki dan memanjangkan umur sebagaimana sabda nabi Muhammad: barangsiapa yang ingin diluaskan rizkinya dan dipanjangkan umurnya hendaknya menyambung sanak keluarganya. Dari perspective hioculutural, super dan Harkness menganalisa keluarga sebagai salah stu komponen yang melengkapi faktor-faktor yang berpengaruh terhadap pertumbuhan dan perilaku Reis, Collins dan Berscheid menunjukkan bahwa sejumlah besar penelitian menunjukkan bahwa keluarga adalah merupakan mediator yang sangat kuat untuk mewujudkan aturan budaya dan norma khususnya yang berkaitan dengan hubungan personal.

Jadi bila para pemimpin keluarga sepakat untuk menumbuhkan etos pendidikan pada anak turun mereka, maka dengan adanya hubungan keluarga yang erat maka akan mudah etos pendidikan ini tumbuh dan bersemai di kalangan mereka. Suasana ini dapat dilihat dari beberapa keluarga transmigran. Misalnya keluarga Tura, Santamin dan Mustafa. Hal serupa dapat ditemukan pada suku Inuit.133 Tatkala mereka memiliki hubungan keluarga yang baik maka tumbuhlah kebahagiaan dan kesejahteraan. Telapi adanya koloniallisme membuat perubahan pada struktur keluarga dan fungsi keluarga yang mengakibatkan munculnya banyak masalah-masalah sosial seperti bunuh diri di kalangan remaja mereka.

Wagimin, Situn, Junaid, Tamid, Santamin, Mustofa dan Parlani, merupakan sosok yang berbeda dibandingkan dengan suku yang sudah tercemar oleh budaya colonial. Wagimin dan kawan- kawan merupakan individu individu yang barn bangkit dengan etos pendidikan menuju hidup yang lebih sejahtera di tanah yang 
relative masih penuh dengan semangat alami yang secara pelan tetapi tidak menyalahi noitna norma yang ada.

Hubungan yang lebih erat didasarkan agama Islam dan pengamalan ajarannya seperti solat lima waktu secara berjamaah, majlis ta'lim atau pegajian rutin merupakan sarana penyemai etos pendidikan yang jitu dengan tambahan hasil hidup sejatera di dunia dan akhirat. Pembicaraan tentang hal ini nampaknya selalu didengungkan dalam setiap pertemuan, bahkan diarahkan oleh para pemuka agama semisal Hasyim dan keluarganya.Hasyim yang pandai memijat nampaknya tidak saja hanya mengendorkan urat saraf maupun otot, tetapi juga meniupkan benih-benih etos ke dalam siapa saja yang bertandang ke rumahnya.

Apabila diperhatikan dari segi periodesasi keluarga transmigran muslim di Pangkoh, maka dapat dibedakan menjadi tiga (3) dasawarsa, yaitu sepuluh tahun pertama, 1982-1991, dasawarsa kedua dari tahun 1992-2001, dan dasawarsa ketiga dan tahun 2002-2011. Dilihat dari segi kondisi tempat tinggal keluarga migran di Pangkoh, tiap-tiap dasawarsa seperti di atas memiliki karakteristik yang sedikit berbeda akan tetap meningkat. Peningkatan terjadi pada beberapa aspek, yaitu aspek pendidikan yang tersedia, sarana pendidikan, kondisi jalan menuju sekolah, kepemilikan alat transportasi, pendapatan, dan kesejahteraan, serta partisipasinya dalam kegiatan agama Islam.

\section{KESIMPULAN}

Etos menempuh pendidikan pada masyarakat migran muslim tergambar pada dua versi, yaitu versi kelompok pertama, migrant muslim yang pendidikan awalnya menengah, dan versi kelompok kedua yang awal tiba hanya berpendidikan dasar. Kelompok pertama, menempuh pendidikan bersamaan dengan tugas abdi Negara, mengambil waktu pada akhir pekan atau waktu libur pengajaran sekolah pada perguruan tinggi sewasta terdekat, di Kuala Kapuas atau perguruan tinggi neggri di kota provinsi tetangga, Banjarmasin dengan jarak tempuh 3 3,5 jam. Beberapa diantaranya menempuh pcndidikan bersamaan.

Dengan anak-anak berkuliah, bedanya abdi Negara ini mendapat dana bantuan belajar Diploma II, selang dua atau tiga tahun melanjutkan ke jenjang sarjana S-1 yang didukung bantuan belajar dari dinas pendidikan atau kantor Kementrian Agama.

Pendidikan tingginya ditempuh pada pertengahan dasawarsa sampai pertengahan dasawarsa III. Pada dasawarsa III, kelompok ini mayoritas sudah sarjana, ada yang Strata-2, memiliki anak yang sarjana dan bekerja menjadi abdi Negara. Pekerjaan pokok usai sarjana meningkat tugas memimpin, kepangkatan dan pendapatan sehingga mereka mampu meningkatkan ibadah, termasuk ibadah umrah, haji, dan membantu sanak saudara kuliah.

Kelompok Kedua, masyarakat migran muslim yang awal kedatangannya berpendidikan dasar, sekolah dasar atau yang sederajat, memiliki etos pendidikan yang tidak langsung. Ketika dasawarsa I, mereka merintis pekerjaan dan kerja keras akan tetapi banyak menghadapi kendala, mengalami hidup susah. Etos menempuh pendidikan mayoritas terkendala, terbatasnya lembaga pendidikan, sarana transportasi, kondisi ekonomi orang tua yang relative lemah. Anak migran mcnempuh pendidikan menengah dan tinggi hampir semua kerjapart time yang 
mengambil upah ketika di kota. Hal ini ditempuh setelah musyawarah dengan orang tua, sebagian keperluan dana pendidikan mencari sendiri, sedangkan bahan mentah konsumsi dipersiapkan dari hasil bertani, bahkan sering orang tua mengantar bahan-bahan itu sekaligus silaturahmi memonitor anaknya. Dasawarsa II - III, Kelompok tidak kalah disbanding anak abdi Negara. Anak migrant dari keluarga berpendidikan dasar juga banyak yang berhasil menjadi sarjana, bahkan ada yang menyelsaikan S-2 dan bekerja, menjadi pemimpin, aktif dalam organisasi Islam dan berkeluarga dengan sarjana.

Keberhasilan orang migran muslim di bidang pendidikan berkaitan dengan etosnya, spirit to fight yang kuat disertai doa, baik doanya sendiri maupun doa kedua orang tuanya. Dengan alasan memudahkan, Variasi kesejahteraan dibedakan menurut kelompok, seperti disebutkan sebelumnya. Kelompok migrant yang awalnya berpendidikan menengah, menjadi sarjana, meningkat penghasilannya, suka bersyukur dan mendanai pendidikan anak-anaknya. Anaknya di sekolahkan pada lembaga pendidikan Agama (pesantren atau madrasah) dan Ia menggunakan sebagian hartanya untuk kebajikan, dan menjadi lebih rajin ke masjid, khususnya pada dasawarsa III.

Kelompok migrant yang awalnya berpendidikan dasar, banyak merasa senang dan mensyukuri keberhasilan anak-anaknya. Anak-anak bekerja seperti yang dimimpikan untuk menjadi abdi Negara. Orang tua merasa sangat berbahagia, karena anaknya baik-baik dan mampu menyenangkan orang tua serta membantu pendidikan adik atau kerabat.

Sebagian kecil dari keluarga migrant yang pendidikan rendah ada meraih sukses luar biasa pada usahanya, uniknuya anak-anaknya tidak boleh sarjana tetapi ketika usai ibadah hajji berubah pikiran. Suami istri menjadi sependapat mengharuskan cucu-cucunya kuliah sampai setinggi-tingginya, dia motivasi dengan hadiah tabungan pendidikan Haji semakin dermawan, banyak ibadahnya dan memperhatikan kerabat dan tetangga yang belum bekerja, termasuk mengundang tenaga kerja dari Jawa.

\section{REFERENSI}

A Conoley, Collie W., and Jane Close Conoley, Positive Psychology and Family Therapy: Creative Techniques and Practical Tools for Guiding Change and Enhancing Growth, Hoboken, N.J.: Wiley, 2009.

Abdul Qodir, Akses Pendidikan Anak Transmigran Kec. Pandih Batt Hasil Penelitian tidak dipublikasikan. Jurusan Tarbiyah, Sekolah Tinggi Agama Islam Negeri Palangka Raya, 2005.

Abdul Wahid, "Origin of Genetic Information and Evolution of Biological Species", Islam \& Science, Vol. 3 Issue: 1, 2005.

Abin Syamsuddin Makmun, 2007, http//, on line 2 Juli 2008.

Achir,Y.C.A., Bakat dan Prestasi disertasi S3, Jakarta: Fakultas Pascasarjana UI. 1990.

Adinugroho, Wahyu Catur, and Bambang Hero Saharjo, Panduan pengendalian kebakaran hutan dan lahan gambut, Bogor: Wetlands InternationalIndonesia Programme : Wildlife Habitat Canada $=$ Habitat Fauniqiie Canada : GEC, 2005. 
Ahmad Janan Assifuddin, Etos Kerja Islami sebuah telaah psikologi, Disertasi Doktor UIN Yogyakarta, 2003.

Ahzami Samiun Jazuli DR., Kehidupan Dalam Pandangan Al Qur'an,-Jakarta: penerbitbukuGemalsnanti press 2006.

Alder, Beth, Motivation, Emotion and Stress, British Psychological Society open learning units Leicester: British Psychological Society, 1999.

Allison, Lincoln, Ecology and Utility: The Philosophical Dilemmas of Planetary Management, Rutherford u.a: Fairleigh Dickinson Univ. Press, 1991.

Allyson Weseley, Robert Mc Entarffer, dan Robert Mc Entarffer. APO Psychology, Hauppauge, N.Y: Barron's Educational Series, 2010.

Kementrian Agama RI. Al- $Q u$ 'an dan Tafsirnya

Amidin, A.S, Kebaikan Air Putih, Yogyakarta: Media Pressindo 2010.

Ardenne, Manfred, Oxygen Multistep Therapy: Physiological and Technical Foundations, Stuttgart ; New York: G. Thieme ; New York : Thieme Medical, 1990.

Ardenne, Manfred. Oxygen Multistep Therapy: Physiological and Technical Foundations, Stuttgart ; New York: G. Thieme ; New York : Thieme Medical, 1990.

Argyle, Michael, The Psychology of Happiness, London: Methuen, 1987.

Argyle, The Psychology of Happiness, New York: Taylor \& Francis. 2001.

Arief, Arifin, Hutan \& kehutanan Deresan, Yogyakarta: Penerbit Kanisius, 2001.

Arshaysky YI. Prog Neurobiol, 2006 Oct; 803:99-113. Epub 2006 Oct 30.

Aspinwall, Lisa G., Ed, US. Staudingcr, Ursula M., Ed, A psychology of human strengths: Fundamental questions and future directions for a positive psychology,
Washington, DC, US: American Psychological Association, 2003.

Atkinson, Paul, Amanda Coffey, dan Sara Delamont, Key Themes in

Qualitative Research: Continuities and Changes, Walnut Creek, Calif: AltaMira Press, 2003.

Avi Kaplan, Stuart A. Karabenick, and Elizabeth de Groot. Culture, Sett; and, Motivation: Essays in Honor of Martin L. Maehr Charlotte, NC: Information Sage Pub, 2009.

Ayala, Francisco Jose, and Theodosius Grigorievich Dobzhansky. Studies in the Philosophy of Biology: Reduction and Related Problems, Berkeley: University of California Press, 1974.

Ayers, Susan, Cambridge Handbook of Psychology, Health and Medicine, Cambridge [etc.]: Cambridge University Press, 2007.

Badan Pusat Statistik, Kalimantan Tengah Dalam Angka, Palangka Raya:BPS., 2010.

Bagodsudjdjadi, M.ed.dan Sitilaila, M.pd., Biologi Sains Dalam Kehidupan, Jakarta,: Yudhistira 2007.

Baranoski, Sharon, and Elizabeth A. Ayello, Wound Care Essentials: Practice Principles, Philadelphia: Lippincott Williams \& Wilkins 2008.

Barbara S. Wallston, Women, gender, and Social Psychology, New Jersey: Lawrence Erlbaum Associates, 1985.

Barrett, Lisa Feldman, dan Peter Salovey, The Wisdom in Feeling Psychological Processes in Emotional Intelligence, New York: Guilford Press, 2002. http://site.ebrary.com/id/1017227 4 .

Barrett, Lisa Feldman, Emotion and Consciousness, New York [u.a.]: Guilford Press, 2005, hlm. 336.

Barton, Len, dan Felicity Armstrong, Policy, Experience and Change: CrossCultural Reflections on Inclusive Education, Inclusive education: cross 
cultural perspectives Dordrecht: Springer, 2008.

Barvosa, Edwina, Wealth of Selves: Multiple Identities, Mestiza Consciousness, and the Subject of Politics, College Station: Texas A\&M University Press, 2008.

Basok, Tanya, Tortillas and Tomatoes Transmigrant Mexican Harvesters in Canad, McGill-Queen's studies in ethnic history Montreal, Que: McGillQueen's University Press, 2002. http://site.ebrary.com/lib/librarytit les/Docid=10119956.

Baudry, M., Thompson, R. F., \& Davis, J. L., Synaptic plasticity:Molecular, cellular, and functional aspects Cambridge, Mass: MIT Press, 1993.

Baudry, M., Thompson, R. F., \& Davis, J. L., Synaptic plasticity: Molecular, cellular, and functional aspects, Cambridge, Mass: MIT Press, 1993.

Baumeister, Roy F., dan Brad J. Bushman, Social Psychology and Human Nature, Belmont, CA: Cengage Learning, 2011.

Belzen, Jacob A., dan Antoon Geels, Mysticism: A Variety of Psychological Perspectives, Amsterdam: Rodopi, 2003.

Benoit, Daniel, dan Marc. Pain, Transmigration et migrations spontanees en Indonesie: provinsi Lampung $=$ Transmigration and spontaneous migrations in Indonesia, Bondy: ORSTOM u.a, 1989.

Bentz, Valerie Malhotra, dan Jeremy J. Shapiro, Mindful Inquiry in Social Research, Thousand Oaks, Calif. [u.a.]: Sage, 1998..

Ben-Ze'ev, Aaron, dan Aaron Ben-Ze'ev, The Subtlety of Emotions, Cambridge, Mass: MIT Press, 2001.

Bernstein, Douglas A, Psychology Belmont, CA: Wadsworth, Cengage Learning, 2012.
Berry, John Widdup, Handbook of CrossCultural Psychology, Boston, MA: Allyn dan Bacon, 1996.

Beverley A, Well-Being: In Search of a Good Life? Bristol, UK: Policy Press, 2008, hlm. 56.

Boller, F., Grafman, J., \& Cermak, L. S., Handbook of neuropsychology, Vol. 2 Amsterdam: Elsevier 2000.

Booth, Char, Reflective Teaching, Effective Learning: Instructional Literacy for Library Educators, Chicago: American Library Association, 2011.

Borkowski, Nancy, Organizational Behavior, Theory, and Design in Health Care, Sudbury, Mass: Jones and Bartlett

Publishers, 2009.

Bosacki, Sandra Leanne, The Culture of Classroom Silence, New York [u.a.]: Lang, 2005.

Breakwell, Glynis M., Research Methods in Psychology, London: Sage Publications, 2006.

Brickman, P. D. Coates, \& R.J. JanoffBulman, Lottery winners and accident victims: Is happiness relative?, Journal of Personality and Social Psychology, 1978.

Bryan, Nathan S, Nitrite and Nitrate in Human Health and Disease, New

York: Humana Press, 2011.

Budiman

Chandra,

PengantarKesehatanLingkungan, Jakarta : EGC 2006.

Bulan, yulistria, Khasiat ikan pada tubuh kita; khasiat ikan pada tubuh kita \& kandungannya, Jakarta; Wahyu Media, 2009.

Burhan Bungin, ed., Analisis Data Penelitian Kualitatif, Jakarta: PT. Raja Grafindo Persada, 2003.

Burns, Nancy, dan Susan K. Grove, The Practice of Nursing Research:

Conduct, Critique, and Utilization, St. Louis, Mo: Elsevier/Saunders, 2005.

Bused, Kamrani, Ilahiah Remaja Pelajar.Telaah Fenomenologis do 
Pendidikan Keluarga Dalam Islam dan Gagasan Implementasi, Banjarmasin: Lanting Media Aksara,2010.

Reinventing Pendidikan Islam:

Menggagas Kembali Pendidikan Islam yang Lebih Baik, Banjarmasin: Antasari Press, 2010.

Buvinie, Mayra, Jacqueline Mazza, dan Ruthanne Deutsch, Social Inclusion and Economic Development in Latin America, Washington, D.C.: Published by the Inter-American Development Bank, 2004.

Byrne, J. H., Concise learning and memory: The editors selection, London, UK: Elsevier/Academic, 2009.

C.R. Snyder dalam Giacalone, Robdrt A., Carole L. Jurkiewicz, dan Craig Dunn, Positive Psychology in Business Ethics and Corporate Responsibility, Greenwich CT: Information Age, 2005.

Cafer Efendi, and Howard Crane. Risale-I MimaTiyye: An Early-SeventeenthCentury Ottoman Treatise on Architecture: Facsimile with Translation and Notes. Studies in Islamic art and architecture, vol. 1 Leiden: E.J. Brill, 1987.

Campbell, Karlyn Kohrs, dan Susan Schultz Huxman, The Rhetorical Act Thinking, Speaking and Writing Critically Belmont, Calif: Wadsworth Pub. Co, 2009, hlm. 238.

Carlson, John G., Edward Smith, Ernest Ropiequet Hilgard, Rita L. Atkinson, dan Patrice Dow-Nelson, Atkinson and Hilgard's Introduction to Psychology, Belmont, CA [u.a]: Wadsworth, 2005.

Caruso, David, dan Peter Salovey, The Emotionally Intelligent Manager: How to Develop and Use the Four Key Emotional Skills of Leadership, San Francisco: Jossey-Bass, 2004.
Chandramohan, A., Human Resource Management New, Delhi: S.B. Nangia, 2008.

Charras, Muriel dan Marc. Pain, Spontaneous Settlements in Indonesia: Agricultural Pioneers in Southern Sumatra, Pemukiman spontan di Indonesia: Perintis Pertanian di Sumatera Selatan Jakarta: Departemen Transmigrasi, 1993.

Chia, Lin Sien, Southeast Asia Transformed A Geography of Change, Singapore: Institute of Southeast Asian Studies, 2003.

Chiras, Daniel D., Human Biology, Boston: Jones and Bartlett Publishers, 2005.

Chisholm, Hugh. The Encyclopcedia Britannica; A Dictionary of Arts, Sciences, Literature and General Information, Cambridge, Eng: At the University press, 1910.

Chisum, W.J., Turvey, B. E., \& ScienceDirect Online service, Crime reconstruction, Amsterdam: Elsevier/Academic Press. 2007.

Clark, Reginald, Family Life and School Achievement: Why Poor Black Children Succeed or Fail, Chicago: University of Chicago Press, 1984.

Cliford Geert dalam Ahmad Janan Assifuddin, 2003.

Cobbs, Elizabeth Lipton, Edmund $\mathrm{H}$. Duthie, dan John B. Murphy,

Geriatrics Review Syllabus: A Core Curriculum in Geriatric Medicine, New York, NY: Blackwell Pub. for the American Geriatrics Society, 2002.

Cohen, Marlene Zichi, David L. Kahn, dan Richard H. Steeves, Hermeneutic Phenomenological Research: A Practical Guide for Nurse Researchers. Methods in nursing research, v. 2 Thousand Oaks, Calif: Sage Pub, 2000. 
Columbus, Frank H, Asian Economic and Political Issues, Huntington, NY: Nova Science Publishers, 1998.

Conny Semiawan, Pendidikan Tinggi: peningkatan kemampuan manusia sepanjang hayat seoptimal mungkin, Jakarta: Grasindo, 1999.

Coon, Dennis, dan John 0. Mitterer, Psychology: A Journey, Belmont, CA: Wadsworth/Cengage Learning, 2011.

Coon, Dennis, John 0. Mitterer, Shawn Talbot, dan Christine M. Vanchella, Introduction to Psychology: Gateways to Mind and Behavior, Belmont, Calif: Wadsworth Cengage Learning, 2010.

Craighead, W. Edward, dan Charles B. Nemeroff, jA - DJ New York [u.a.]: Wiley, 2001, hlm. 149.

Cranney, Jacquelyn, and Dana Dunn, The Psychologically Literate Citizen: Foundations and Global Perspectives, New York: Oxford University Press, 2011.

Cribb, Robert, dan Audrey Kahin dalam Historical Dictionary of Indonesia, Lanham Maryland: Scarecrow Press, 2004.

Cropley, David, The Dark Side of Creativity, Cambridge: Cambridge University Press, 2010. http://lib.myilibrary.com?id=2658 00 .

Csikszentmihalyi, 1999. If we are so rich, why aren't we happy? Diener, E., Subjective well-being: the science of happiness and a proposal for a national index, American Psychologist, 2000.

Csikszentmihalyi, Mihaly, A Life Worth Living: Contributions to Positive Psychology, Oxford: Oxford Univ. Press, 2006.

Danandjaya, James, Antropologi Psikologi, Jakarta: PT. RaJawali Press, cet.I11,1988.

Dantzker, Ronald D. Hunter dalam bukunya "Research Methods for Criminology and Criminal .Justice" 2011, him. 246
David Charles, dan Daniel J. Ozer, Pieces of the Personality Puzzle: Readings in Theory and Research, New York: W. W. Norton, 2007.

David, Arthur De Silva, New Testament Themes, Chalice Press, 2001.

Davies, Alan, dan C. Elder, The Handbook of Applied Linguistics, Blackwell handbooks in linguistics, 17. Malden, Mass: Blackwell Pub, 2004.

Deary, I. J, Intelligence: A very short introduction, Oxford [u.a.]:

Oxford Univ. Press, 2001.

Delinom, Robert M., and Dyah Marganingrum, Sumber daya air dan lingkungan: potensi, degradasi, dan masa depan, Jakarta: Lembaga Ilmu Pengetahuan Indonesia, 2007.

Delle Fave, Antonella, Fausto Massimini, dan Marta Bassi, Psychological Selection and Optimal Experience Across Cultures: Social Empowerment Through Personal Growth, Dordrecht: Springer Science Business Media B.V., 2011.

Departemen Pendidikan Nasional, Penjelasan Peraturan Pemerintah RI Nomor 19 tahun 2005.

Dere, E., Handbook of episodic memory, Amsterdam: Elsevier Science, 2008.

Diener dan Scollon, Subjective well being is desirable, but not the summun bonum. Paper delivered at the University of Minnesota interdisciplinary Workshop on Well-Being, October $23-25$, 2003, Minneapolis.

Diener E., Assessing well-being: the collected works of Ed Diener, New York: Springer; 2009.

, Subjective Well-being. The Science of Happiness and Proposal for a national index, American psychologist, 55; 2000.

Diener, E.M. Suh, R.E. Lucas, \& H.L. Smith, Subjective Well-Being: Three Decades of Progress, Psychological bulletin, 1999 .. 
Diener, Ed, and Robert Biswas-Diener Happiness: Unlocking the Mysteries of Psychological Wealth, Blackwell Publishing, Malden, MA. 2011.

Diener, Ed, Culture and Well-Being: The Collected Works of Ed Diener, Dordrecht: Springer, 2009.

Diener, Ed, dan Ed Diener, Assessing WellBeing: The Collected Works of Ed Diener, Dordrecht: Springer, 2009.

Diener, Ed, dan Eunkook M. Suh, Culture and Subjective Well-Being, Cambridge, Mass: MIT Press, 2000.

Diener, Ed, dan Robert Biswas-Diener, Happiness: Unlocking the Mysteries of Psychological Wealth, Malden, MA: Blackwell Pub, 2008.

Diener, Ed, Daniel Kahneman, dan Norbert Schwarz, Well-Being: The Foundations of Hedonic Psychology, New York, NY: Russell Sage Foundation, 2003.

Diener, Ed, The Science of Well-Being: The Collected Works of Ed Diener, Dordrecht:

Springer, 2009. Diener, Ed,dan Raksha Arora, Assessing Well-Being, Dordrecht: Springer, 2009. Diener, Edward dkk. Subjective Well Being, Three Decades of Progress, Psychological Bulletin, 1999.

Dilip G. Saraf, The 7 Keys to a Dream Job, Nirvana Books, 2004.

Ding, Sharon, dan Karen Littleton, Children's Personal and Social Development, Malden, MA: Blackwell Pub, 2005.

Djanius Djamin, Suatu Analisis Sosial, Pengawasan dan Pelaksanaan Undang-undang Lingkungan, Jakarta: Yayasan Obor Indonesia, 2007.

DOrnyei, Zoltan, and Richard W. Schmidt, Motivation and Second Language Acquisition, Honolulu, Hawaii: Second Language Teaching \& Curriculum Center, University of Hawai'i at Manoa, 2001.
Drane, J. F. Becoming a good doctor: The place of virtue and character in medical ethics, Kansas City, MO: Sheed \& Ward, 1988.

Duggan, Christopher, John B. Watkins, and W. Allan Walker. Nutrition in Pediatrics: Basic Science, Clinical Application, Hamilton: BC Decker, 2008.

E. Diener, \& R. B. Diener, Finding on Subjective Well-Being and Their Implications for Empowerment This paper was presented at the Workshop on Measuring Empowerment: Cross Disciplinary Perspectives held at the World Bank in Washington, DC on February 4 and 5, 2003. Eckersley, Richard, Jane Dixon dan Bob Douglas, The Social Origins of Health and Well-Being, Cambridge: Cambridge University Press, 2001.

Edlin, Gordon, dan Eric Golanty, Health \& Wellness Sudbury, Mass: Jones and Bartlett Publishers, 2010.

Edward Artin dkk., Webster The New International Dictionary, USA: G \& C Merriam CO., Vol. I, 1981.

Ehrlich, C. S., Saul in story and tradition, Tubingen: Mohr Siebeck 2006.

Eleanor H. Porter in which Pollyanna is always able to look on the bright side of any event.

Emma PandiWirakusuinali, M.Sc., Sehal Cara Al 'quran Dan Hadits, Jakarta, selatan: hikmah Ptmizan publika 2010.

Enghag, Per, Encyclopedia of the Elements Technical Data, History,

Processing, Applications, Weinheim: Wiley$\mathrm{VCH}, 2004$.

Eric Schroeder transltr, Muhammad's People: A Tale by Anthology, Portland, ME: Bond Wheelwright, 1955.

F.X. Sri Sudewo, Burhan Bungin eds, 2003, hlm.186. dan Suwardi 
Endraswara, Penelitian Kebudayaan, Yogyakarta: Pustaka Widyatama, 2006.

Fahey, Tony, Bernadette C. Hayes, dan Richard Sinnott, Conflict and Consensus: A Study of Values and Attitudes in the Republic of Ireland and Northern Ireland,

Dublin: Institute of Public Administration, 2005.

Fahraeus, A., \& Jonsson, A. K., Textual ethos studies or locating ethics, Amsterdam: Rodopi 2005.

Farndon, John, Oxygen, New York: Benchmark Books/Marshall Cavendish, 1999.

Feinstein, Sheryl, The Praeger Handbook of Learning and the Brain, Westport, Conn: Praeger, 2006.

Feldman, Fred, What Is This Thing Called Happiness?, Oxford [etc.]: Oxford University Press, 2010.

Fiske, S. T., Gilbert, D. T., \& Lindzey, G., The handbook of social psychology, Hoboken, N.J: Wiley 2010.

Flick, Uwe, Ernst von Kardorff, dan Ines Steinke, A Companion to Qualitative Research, London [u.a.]: SAGE, 2004.

Francis, Leslie J., dan Jeff Astley, Psychological Perspectives on Prayer: A Reader, Leominster: Gracewing, 2001..

Gade, Anna M., Perfection Makes Practice: Learning, Emotion, and the Recited Qur'an in Indonesia, Honolulu: University of Hawai'i Press, $2004 .$.

Ganguly, A. P., Netaji Subhas confrontedthe Indian ethos, 1900-1921:- Yogi Sri Aurobindo's 'Terrorism, poetTagore's 'Universalism, and Mahatma Gandhi's 'Experimental non-violence, Dehra Dun, Uttaranchal, India: Vedantic Res. Publ 2003.

Gardner, William L., Bruce J. Avolio, dan Fred 0. Walumbwa, Authentic Leadership Theory and Practice: Origins, Effects and Development,
Amsterdam, Netherlands: Elsevier, 2005.

Gary Anderson \& Michael Stone eds, Literature on Adam and Eve: Collected Essays, Boston: Brill, 2000.

Geiger, Roger Edt, History of Higher Education Annual: 1996 V, [S.1.]: History Of Higher Educ, 1996.

Gerda Sian, Educational Psychology in Changing World, London: Unwin Hymen, 1988.

Giacalone, Robert A., Carole L. Jurkiewicz, dan Craig Dunn, Positive Psychology in Business Ethics and Corporate Responsibility, Greenwich, CT: Information Age Pub. Inc, 2005.

Gibbs, Paul T., Trusting in the University: The Contribution of Temporality and Trust to a Praxis of Higher Learning, Dordrecht [u.a.]: Kluwer Academic, 2004.

Glowinkowski, Steve, It's Behaviour, Stupid!: What Really Drives the Performance of Your Organisation, Penryn: Ecademy Press, 2009.

Good, Mary-Jo Del Vechio, American Medicine, Berkeley: University of California Press, 1998.

Gorman, Tom, Motivation: Spark Initiative, Inspire Action, Achieve Your Goal, Avon, Mass: Adams Media, 2007.

Gorsuch, Richard L, Integrating Psychology and Spirituality?, Westport, Conn: Praeger, 2002.

Gracia, J. J. E., \& Young, J., Uses and abuses of the classics: Western Interpretations of Greek philosophy, Aldershot: Ashgate, 2004.

Gregerson, Mary Banks, The cinematic mirror for psychology and life coaching, New York, N.Y: Springer, 2010.

Grim, John, The Shaman: Patterns of Religious Healing Among the Ojibway Indians, Norman, Okla: University of Oklahoma Press, 1987. 
Gross, James J, Handbook of Emotion Regulation, New York: Guilford Press, 2007.

Gudykunst, William B, Theorizing About InterculturalCommunication, Thousand Oaks [u.a.]: Sage Publ, 2005.

H.R. Daeng Naja, SH., MHum., Mkn Kebijakan kredit yang berwawasan lingkungan, Yogyakarta, 2007.

Hall, P. A., Russell, S. E. H., \& Pringle, J. R., The septins, Oxford: John WileyBlackwell, 2008.

Harry, Wied Apriadji, Good Mood Food, Jakarta: Gramedia Pustaka Utama, 2007.

Harvey Russell Bernard dalam buku berjudul "Social Research Methods: qualitative and quantitative aproach" ,Sage Pub. Thousand Oaks, California: 2000,

Hatab, Lawrence J., Ethics and Finitude: Heideggerian Contributions to Moral Philosophy, Lanham [u.a.]: Rowman \& Littlefield, 2000.

Haydon, Graham, Values for Educational Leadership, Los Angeles, CAL: Paul Chapman, 2007.

Heidegger, Martin, History of the Concept of Time: Prolegomena, Bloomington: Indiana University Press, 1992.

Heimbrock, Hans-Gtinter, dan Christopher P. Scholtz, Religion: immediate experience and the mediacy of research interdisciplinary studies, concepts and methodology of empirical research in religion, GOttingen: Vandenhoeck \& Ruprecht, 2007.

Helth, vitha, Rahasia sehat clengan makan berkhasiat, Jakarta: Kompas Media Nusantara, 2009.

Hembing Wijayakusuma, Bebas Diabetes Mellitus Ala Hembing Jakarta: Puspa Swara, 2004.
Hendro Sunarjono, Berkebun 21 Jenis Tanaman Buah, Jakarta; Penebar Swadaya, 2008..

Hersen, Michel, dan Jay C. Thomas, Personality and Everyday Functioning: Comprehensive handbook of personality and psychopathology, Michel Hersen eds.in-chief, Vol. 1 Hoboken, NJ: John Wiley, 2006.

Hershock, Peter D., Mark Mason, dan John N. Hawkins, Changing Education: Leadership, Innovation and Development in a Globalizing Asia Pacific, [S.1.]: Springer, 2007..

Higbee, K. L., Your memory: How it works and how to improve it, Cambridge, MA: Da Capo, 2001.

Hindery, Roderick, Comparative Ethics in Hindu and Buddhist Traditions, Delhi, [India]: Motilal Banarsidass, 1996.

Hof, Patrick R., and Charles V. Mobbs. Handbook of the Neuroscience of Aging, Amsterdam: Elsevier/Academic Press, 2009. Hogan, Robert, Stephen R. Briggs, dan John Johnson, Handbook of Personality Psycholog, San Diego: Academic Press, 1995.

Holleman, A. F., Egon Wiberg, Nils Wiberg, Mary Eagleson, William Brewer, dan Bernhard J. Aylett. Inorganic Chemistry, San Diego: Academic Press, 2001.

Hollway, Wendy, dan Tony Jefferson, Doing Qualitative Research Differently: Free Association, Narrative and the Interview Method, London [u.a.]: SAGE Publ, 2000.

Holodynski, Manfred, dan Wolfgang Friedlmeier, Development of Emotions and Emotion Regulation New York: Springer, 2006, http://site.ebrary.com/id/1015084 7, hlm. 60 .

Holt, Larry C., dan Marcella L. Kysilka, Instructional Patterns: Strategies for

Etos Pendidikan dan Kesejahteraan Migran Muslim Studi Kasus di Pemukiman Migran Pangkoh Kab. Pulang Pisau Provinsi Kalimantan Tengah. 
Maximizing Student Learning, Thousand Oaks, Calif: SAGE Publications, 2006. http://akhmad sudrajat.wordpress.2008/02/06 on line 6 Pebruari 2010.

Horowitz, Leonard M., dan Stephen Strack, Handbook of Interpersonal Psychology:Theory, Research, Assessment and Therapeutic Interventions, Hoboken, N.J.: Wiley, 2011.

Hoshmand, Lisa Tsoi, Culture, Psychotherapy, and Counseling: Critical and Integrative Perspectives, Thousand Oaks, Calif: Sage Publications, 2006.

Hota, Ashok K., Creativity: cultural perspective, New Delhi: Discovery Pub. House, 2000.

Humphrey, Ronald H., Affect and Emotion: New Directions in Management : Theory and Research, Charlotte, NC: Information Age Pub, 2008.

Hunt, Andrew, and Robin Millar. AS Science for Public Understanding, Oxford [u.a.]: Heinemann Educational, 2000.

Hyde, Michael J., The Ethos of Rhetoric, Columbia, SC: Univ. of South Carolina Press, 2004.

Ibn al-Arabi, The Bezels of Wisdom, New York: Paulist Press, 1980.

Ide, pangkalan, Diet Atkins; diet mulai dari tubuh kita dan makanannya, Jakarta: Elex Media Komputindo, 2007.

Imam Setyobudi, Menari di antara sawah dan kota: ambiguitas diri petanipetani terakhir di Yogyakarta, Magelang: IndonesiaTera, 2001.

Ing. Sunarto Tjahj ad, Data Arsitek Jakarta: Erlangga 1996, hlm. 112.

Inglehart, Ronald, Islam, Gender, Culture, and Democracy: Findings from the World Values Survey and the European Values Survey, Willowdale, Ont: De Sitter Publ, 2003.

Ingrid E. Josephs, Dialogicality in Development, Westport, Conn. [u.a.]: Praeger, 2003.
International Business Publications, USA., Indonesia Business Law Handbook, International Business Pubns USA, 2007 ,

Irving, T. B., Ahmad, K., dan Ahsan, M. M., The Qur'an Basic teachings : an anthology of selected passages from the Qur'an, translated into contemporary English with an introduction to the message of the Qur'an, Leicester Leicestershire: 1979.

Ismanthono, Henricus W., Kamus istilah ekonomi populer, Jakarta: Penerbit Buku Kompas, 2003.

Jackson, Paul, and Manfusa Shams, Developments in Work and Organizational Psychology: Implications for International Business, International business and management series, 20 Amsterdam [u.a.]: Elsevier, 2006.

James Dananjaya, Antropologi Psikolog Cet.10 Jakarta:Rinke Cipta,1988, hlm. 8.

Janette B. Benson, dan Marshall M. Haith, Social and Emotional Development in Infancy and Early Childhood, Amsterdam: Elsevier/Academic Press, 2009.

Jarvis, Matt, Teori-Teori Psikologi: Pendekatan Modern Untuk Memahami Perilaku, Perasaan dan Pikiran Manusia Terjemahan SPA Teamwork, Cet IV Bandung: Nusa Media, 2010.

John D. Caputo Caputo, John D, Radical Hermeneutics: Repetition,

Deconstruction, and the Hermeneutic Project,Bloomington: Indiana University Press, 1987.

John Hirst. The Shortest History of Europe, Melbourne: Black Inc., 2009.

John, Oliver P., Richard W. Robins, dan Lawrence A. Pervin, Handbook of Personality: Theory and Research New York: Guilford Press, 2008, him. 639. 
Johnson, William C., Child Development and Teaming, New York: MSS Information Corp, 1973.

Josephson, Michael S., dan Wes Hanson, The Power of Character: Prominent Americans Talk About Life, Family, Work Values, and More, Bloomington, Ind: Unlimited Pub, 2004.

Jumarani, louise, The essense of Indonesian spa Jakarta: Gramedia Pustaka Utama, 2009, him. 1-7.

Kaltner, J. Introducing the Qur'an: For today's reader, Minneapolis: Fortress Press 2011

Kantor Biro Statistik Provinsi Kalimantan Tengah tahun 2009; dan bandingkan dengan data pada Kantor Biro Statistik Kabupaten Pulang Pisau Januari 2010.

Kantor wilayah transmigrasi, Dokumen Kantor Wilayah Transmigrasi Provinsi Kalimantan Tengah, mulai otonomi Daerah instansi ini berubah nama menjadi Dinas Kependudukan, Tenaga Kerja dan Transmigrasi.

Kasinitz, Philip, Inheriting the City: The Children of Immigrants Come of Age, New York: Russell Sage Foundation [u.a.], 2008.

Kebschull, Dietrich, Transmigration in Indonesia: An Empirical Analysis of Motivation, Expectations, dan Experiences, Hamburg: Verlag Weltarchive, 1986.

Kecamatan Pandih Batu, Dokumen kantor kecamatan Pandih Batu tentang data desa di wilayah kecamatan Pandih Batu tahun 2011.

Kelner, Stephen P, Motivate Your Writing!, Hanover, NH: University Press of New England, 2005.

Kementerian Agama RI, Al-Qur'an dan Tafsirnya, edisi yang disempurnakan, Jakarta: Kementerian Agama RI, 2009.
Kevin Marjoribanks, Families and their learning environments: an empirical analysis.

Kidd, and Renee 2006, hlm.10,

Kitayama, Shinobu, dan Dov Cohen, Handbook of Cultural Psychology, New York: Guilford, 2001.

Kitayama, Shinobu, dan Hazel Markus,

Emotion and Culture: Empirical Studies of Mutual Influence, Washington, DC: American Psychological Association, 1997.

Kitayama, Shinobu, Handbook of Cultural Psychology, New York, NY [u.a.]: Guilford Press, 2010.

Klausen, M. P., Neurogenesis research advances, New York: Nova Science Publishers, 2007.

Kluegel, James R., David S. Mason, dan Bernd Wegener, Social Justice and Political Change: Public Opinion in Capitalist and Post-Communist States, New York: A. de Gruyter, 1995.

Kodoatie, Robert J., Roestam Sjarief, and Suci Nurasih, Tata ruang air, Yogyakarta: Andi, 2010.

Koentjaraningrat, Metode-Metode Penelitian Masyarakat, Jakarta: Gramedia,1996.

Koontz, Harold, dan Heinz Weihrich, Essentials of Management: An International Perspective, New Delhi: Tata McGraw-Hill, 2007.

Kopala, Mary, dan Lisa A. Suzuki, Using Qualitative Methods in Psychology, Thousand Oaks, Calif: Sage, 1998.

Kring, Ann M., and Denise M. Sloan, Emotion Regulation and Psychopathology A Transdiagnostic Approach to Etiology and Treatment, New York, NY: Guilford Press, 2010. http://public.eblib.com/EBLPublic /PublicView.do?ptiID=464910, hlm. 233.

Krueger, Alan B, Measuring the Subjective Well-Being of Nations National Accounts of Time Use and Well-Being, Chicago: University of Chicago Press, 
2009.

http://www.myilibrary.com?id=24

2665, hlm. 233;

Krumhardt, Barbara, I. Edward Alcamo, and

I. Edward Alcamo. Barron's E-Z Anatomy and Physiology, Hauppauge, N.Y.: Barron's Educational Series, 2010.

Kundu, C. L., dan D. N. Tutoo, Educational Psychology, New Delhi: Sterling, 1985.

Kvale, Steinar, Interviews An Introduction to Qualitative research Interviewing, Thousand Oaks [u.a]: Sage publ, 1997.

Lamb, Michael E., The Role of the Father in Child Development, Hoboken, N.J: Wiley, 2010.

Laming, D. R. J., Understanding Human Motivation What Makes People Tick?, Malden, Mass: Blackwell Pub, 2004. http://site.ebrary.com/id/1023301 3 .

Landy, Frank J., dan Jeffrey M. Conte, Work in the 21st Century: An Introduction to Industrial and Organizational Psychology,Hoboken, NJ: Wiley, 2010.

Lang, Susan S., dan Richard B. Patt, You Don't Have to Suffer: A Complete Guide to Relieving Cancer Pain for Patients and Their Families, New York: Oxford University Press, 1995.

Larsen, Randy J., and Michael Eid. The Science of Subjective Well-Being, New York: Guilford Press, 2008.

Latham, Gary P., Work Motivation: History, Theory, Research, and Practice, Thousand Oaks: Sage Publications, 2007.

Lazarus, Richard S, Stress and Emotion: A New Synthesis, New York, NY: Springer, 2006.

Leary, Mark R., dan Rick H. Hoyle, Handbook of Individual Differences in Social Behavior, New York, N.Y., [etc.]: The Guilford Press, 2009.

Leavitt, Harold. J., Louis R. Pondy, dan David M. Boje, Readings in
Managerial Psychology, Chicago: University of Chicago Press, 1989.

Lehrer, Paul M., Robert L. Woolfolk, dan Wesley E. Sime, Principles and Practice of Stress Management, Ncw York: Guilford Press, 2007.

Leo Jones, Cambridge University Press, 2002.

Levang, P., Ayo ke tanah sabrang: transmigrasi di Indonesia, Jakarta: Kepustakaan Populer Gramedia, 2003.

Lewis, Michael, Handbook of Emotions New, York, NY [u.a.]: Guilford, 2010.

Lex Hixon and Neil Douglas-Klotz. The heart of the Qur'an: an Introduction to Islamic spirituality, Wheaton, Ill. [u.a.]: Quest, 2003..

LGunawan, I. Ketut, The Politics of the Indonesian Rainforest: A Rise of Forest Conflicts in East Kalimantan During Indonesia's Early Stage of Democratisation, Gottingen: Cuvillier, 2004.

Lichtman, Marilyn, Qualitative Research in Education: A User's Guide, Los Angeles: SAGE, 2010.

Lightfoot, Anthony, Dr. Parallel of Words, [S.1.]: Authorhouse, 2010..

Lightman, Dana, Power Optimism: Enjoy the Life You Have, Create the Success You Want Abington, PA: Power Optimism, 2004.

Lopez, Shane J, Positive Psychology: Exploring the Best in People, Westport: Praeger, 2008.

Lopez, Shane J, The Encyclopedia of Positive Psychology, Chichester, U.K.: Wiley-Blackwell Pub, 2009. http://public.eblib.comlEBLPublic /PublicView.do?ptiID=437527, him. 455.

Louie dan Vivian S., Compelled to Excel: Immigration, Education, and Opportunity Among Chinese Americans, Stanford, Calif: Stanford University Press, 2004..

Lucas, Robert W., People Strategies for Trainers: 165 Tips and Techniques for 
Dealing with Difficult Classroom Situations, New York: American

Management Association, 2005.

Lyubomirsky K. M., 2006., Ross, L. 1999, Changes in attractiveness of Selected and Precluded Alternatives: A Comparation of happy and unhappy individuals. Journal of personality and Social Psychology. 76, 988-1007.

M. Csikszentmihalyi, If we are so rich, why aren't we happy?, American Psychologist, 1999.

M. Rajamanickam dalam bukunya berjudul "Statistical Methods In Psychological And Educational Research" 2001.

M.J. Packer, Hermeneutics inquiry.

Mace, N. L., \& Rabins, The 36-hour day: A family guide to caring for people with alzheimer disease, other dementias, and memory loss in later life, Baltimore, Md: John Hopkins University Press, 2006.

Macintyre, Stuart, dan Anna Clark, The History Wars, Carlton: Melbourne University Press, 2004.

Maddux, James E., dan June Price Tangney, Social Psychological Foundations of Clinical Psychology, New York: Guilford Press, 2010.

Made Astawan dan Andreas Leomitro Kasih, Khasiat Warna-Warni Makanan, Jakarta: Gramedia, 2008.

Maio, Gregory R., dan Geoffrey Haddock, The Psychology of Attitudes and Attitude Change, London: SAGE, 2009.

Maisto, S. A., Galizio, M., \& Connors, G. J, Drug use and abuse, Belmont, CA: Wadsworth. Maisto, 2011.

Mallon, Brenda, Dying: Working with Adult Bereavement, London: Sage, 2008.

Marendra, zulfito, Ikan sehat dan tubuh kita; Pemberian sejak dini, Jakarta: Wahyu Media, 2009.

Marendra, zulfito, Sehat Dan Permainan Untuk Meningkatkan Kccerdasan Anak, Jakarta: Gagas Media, 2009.
Marks, David F., Health Psychology: Theory, Research and Practice, Los Angeles, Calif. ; London: Sage, 2011.

Martin SJ, Grimwood PD, Morris RG. Synaptic plasticity and memory: an evaluation of the hypothesis. Masters, R. D., \& McGuire, M. T., The Neurotransmitter revolution: Serotonin, social behavior, and the law, Carbondale: Southern Illinois University Press, 1994.

Masiimian, Farnaz, Life After Death: A Study of the Afterlife in World Religions, Los Angeles: Kalimat Press, 2002.

Mayne, Tracy, Emotions: Current Issues and Future Directions, NewYork: Guilford Press, 2001.

McArdle, William D., Frank I. Katch, and Victor L. Katch, Essentials of Exercise Physiology, Baltimore, Mar: Lippincott Williams \& Wilkins, 2006.

McConnell, J. V., \& Philipchalk, R. P., Understanding human behavior, Fort Worth: Harcourt Brace Jovanovich College Publishers, 1992.

McCrae, R.R. Mainstream personality psychology and the study of religion, Journal of Personality, 1999.

McDowell, Julie, Encyclopedia of Human Body Systems, Santa Barbara: Greenwood, 2010.

McManus, I. C. Right Hand, Left Hand: The Origins of Asymmetry in Brains, Bodies, Atoms, and Cultures, Cambridge, Mass: Harvard University Press, 2002.

McWhorter, Ladelle dan Gail Stenstad, Heidegger and the Earth: Essays in Environmental Philosophy, Toronto: University of Toronto Press, 2009.

Merriam, Sharan B., dan Sharan B. Merriam, Qualitative Research: A Guide to Design and Implementation, San Francisco: Jossey-Bass, 2009.

Michael D. Eldridge, Dying Adam with

Etos Pendidikan dan Kesejahteraan Migran Muslim Studi Kasus di Pemukiman Migran Pangkoh Kab. Pulang Pisau Provinsi Kalimantan Tengah. 
His Multiethnic Family:

Understanding the Yunani Life of Adam and Eve, Boston: Brill, 2001.

Michael E. Lamb, The Role of the Father in

Child Development, Hoboken, N.J.: Wiley, 2010.

Michael J. Hyde, The Ethos of Rhetoric, Columbia: Univ of South Carolina Press, 2004.

Michalos, Alex C, Citation Classics from Social Indicators Research: The Most Cited Articles Edited and Introduced, Dordrecht: Springer, 2005.

Mien Ahmad Rifai, Manusia Madura, Yogyakarta: Pilar Media, 2007.

Mike Howarth, Britain's Educational Reform: A Comparison with Japan, London: Routledge, 1990.

Miles, Matthew B., dan A. Michael Huberman, Qualitative data analysis, Thousand Oaks [etc.]: Sage, 1994.

Misra, Girishwar, and Ajit K. Mohanty, Perspectives on Indigenous Psychology, New Delhi: Concept Pub. Co, 2002.

Mobile Reference, Neurophysiology Study Guide, Boston: MobileReference.com, 2007.

Moehd. Baga Kalie, Rambutan Varietas Unggul, Yogyakarta; Kanisius, 1994.

Moh. Ali Aziz, Rr. Suhartini, dan A. Halim, Dakwah pemberdayaan masyarakat: paradigma aksi metodologi Sewon, Bantul, Yogyakarta: Pustaka Pesantren atas kerjasama dengan Dakwah Press, Fakult2s Dakwah, IAIN Sunan Ampel Surabaya, 2005..

Moleong, Metodologi Penelitian Kualitatif

Bandung: CV. Rosda Karya, 1995.

Monferrer Sala, Juan Pedro, dan Angel Urban, Sacred text: explorations

in lexicography, Frankfurt am Main: Peter Lang, 2009.;

Mortensen, Kurt W., Maximum Influence

The 12 Universal Laws of Power Persuasion, New York: American Management Association, 2004.
Muchlisin, Saatnya Orang Transmigran Angkat Bicara, Harian Kalteng Pos, tanggal 22 Pebruari 2008.

Muchtar Buchori, Penelitian Pendidikan dan Pendidikan Islam di Indonesia, Jakarta: IKIP Muhammadiyah Press, 1994.

Muhadjir, Noeng, Metodologi Penelitian Kualitatif Edisi 4 Yogyakarta: Rake Sarasin, 2002.

Muhammad 'Aliy al-Khuliy, Dictionary of Education, English - Arabic, Bairut: Darul-"Ilmil-Malayin, 1981 dalam Ahmad Janan Asifuddin, 2003.

Muhammad Noor, Pertanian Lahan Gambut Potensi dan Kendala, Yogyakarta:Kanisius, 2001.

Muhammad Nur, Pertanian Lahan Gambut, Yogyakarta: Kanisius, 2001..

Mulyasa.E, Manajemen Pendidikan Karakter, Jakarta: PT. Bumi Aksara, 2011.

Munroe, Myles, Kingdom Principles: Preparing for Kingdom Experience and Expansion, Shippensburg, PA: Destiny Image Publishers, 2006.

Musa Asy'arie, Islam, Etos Kerja dan Pemberdayaan Ekonomi Umat, Yogyakarta: Lesfi, 1997.

Myers, American Paradox, New York: Worth publishers. 2004. , Funds, friends, and faith of happy

people, American Psychologist, 2000.

Nash, Jeffrey E., dan James M. Calonico, The Meanings of Social Interaction: An Introduction to Social Psychology, Dix Hills, N.Y.: General Hall, 1996.

Nasir, Muhammad, Rahasia kecerdasan anak, Jakarta: Kompas Media Nusantara, 2010.

Nasr, Seyyed Hossein, Traditional Islam in the Modern World, London: KPI, 1987.

Negi, Nalini, and Furman Rich, Transnalional Social Work Practice, New York: Columbia University Press, 2010. 
Nel, Philip Johannes, The Structure and Ethos of the Wisdom Admonitions in Proverbs, Berlin: W. de Gruyter, 1982.

Nelson, James M., Psychology, Religion, and Spirituality, New York: Springer, 2009.

Nicholas S, An Introduction to the Sociology of Law, New Brunswick, N.J.: Transaction Publishers, 2002..

Nuralamsyah, Andi, Minyak penakluk aneka penyakit, Jakarta: Agro Media, 2005.

Nurcholis Majid, Fatsoen, Jakarta: Penerbit Republika, 2002. Islam Doktrin dan Peradaban, Jakarta: Yayasan Wakaf Paramadina, Cet. ke-3. 1995.

Nurul Chomaria, Membabat Virus Nganggur: Saatnya menciptakan pekerjaan bukan mencari pekerjaan, Solo: Samudera, 2007.

NykliZek, Ivan, A. J. J. M. Vingerhoets dan Marcel Zeelenberg, Emotion Regulation and Well-Being, New York: Springer, 2011. < http: //dx. doi. or g/ 10. 1007/978- 14419-69538 .

Pastorino, Ellen, dan Susann Doyle-Portillo, What Is Psychology?: Essentials, Australia: Wadsworth Cengage, 2010.

Perretta, Lorraine, Makanan Untuk Otak dan tubuh, Jakarta: Erlangga, 2007.

Peruniak, Geoffrey, A Quality of Life Approachto Career, Development University of Toronto Press, 2010.

Phillip L. Harriman, Pedoman untuk Mengetahui Istilah Psikologi, Handbook of Psychology Term, Ted. MW. Husodo Jakarta: Restu Agung, 1995.

Phillips, Jean, dan Stanley Morris Gully, Organizational Behavior: Tools for Success, Mason, Ohio: South-Western Cengage Learning, 2012.

Piedmont, Ralph L, Research in the Social Scientific Study of Religion, Leiden: Brill, 2007.
Pinel, John. P. J., Biopsychology seventh edition, Boston, Mass: Pearson Allyn and Bacon, 2008. Terjemahan Helly Prajitno Soetjipto dan Sri Mulyantini Soetjipto, 2009.

Plotnik, R., \& Kouyoumjian, H., Introduction to psychology,Belmont, CA: Wadsworth/Cengage Learning, 2011.

Poon, Leonard W., dan Jiska CohenMansfield, Understanding Well-Being in the Oldest Old Psychological Perspectives on Aging, Cambridge: Cambridge University Press, 2011.

Poon, Leonard W.,dan Thomas T. Perls, Biopsychosocial Approaches to Longevity, New York: Springer, 2008.

Preiser, Wolfgang F. E, Building Evaluation, New York: Plenum Press, 1989.

Rachael C. Murrihy, Antony D. Kidman, dan Thomas H. 011endick, Clinical Handbook of Assessing and Treating Conduct Problems in Youth, New York: Springer, 2010.

Radical Hermeneutics: Repetition, Caputo, John D., Deconstruction, and the Hermeneutic Project, Bloomington: Indiana University Press, 1987.

Radway, Janice A., American Studies: An Anthology, Chichester, U.K: WileyBlackwell, 2009.

Rafiabadi, H. N., World Religions and Islam: A Critical Study, New Delhi: Sarup \& Sons, 2003.

Rahmat Rukmana dan Yuyun Yuniarsih, Rambutan Komoditas Unggulan Prospek Agribisnis, Yogyakarta; Kanisius, 2002.

Rajawali Foundation Jakarta, Indonesia menentukan nasib: dari reformasi ke transformasi kelembagaan, Jakarta: Buku Kompas, 2010.

Reginald Clark, Family Life and School Achievement: Why Poor Black Children Succeed or Fail, Chicago: University of Chicago Press, 1984. 
Repetto, Robert C., Public Policies and the Misuse of Forest Resources, Cambridge United Kingdom Academic [u.a.]: Cambridge Univ. Press, 1988.

Richard Swedberg, The Max Weber Dictionary Key Words and Central Concepts, Stanford, Calif: Stanford Social Sciences, 2005.

Richardson, John The Handbook of Qualitative Research Methods for Psychology and the Social Sciences, Leicester: BPS Books, 1996.

Riepe, Dale, dan Marvin Farber, Phenomenology and Natural Existence: Essays in Honor of Marvin Farber, Albany: State University of New York Press, 1973.

Risza, Suyatno, Masa depan perkebunan Kelapa sawit Indonesia, Yogyakarta, Indonesia: Penerbit Kanisius, 2010.

Robak, Rostyslaw, A Primer for Today's Substance Abuse Counselor, New York: Lexington Books, 1991.

Robbins, Stephen P., Organizational Behavior : Global and Southern African Perspectives, Cape Town: Pearson Education South Africa, 2009.

Robert R. Bianchi, Guests of God:Pilgrimage and Politics in the Islamic World, New York: Oxford University Press, 2004.

Roeckelein, Jhon E., Elsevier's Dictionary of Psychological Theories, Amsterdam [u.a.]: Elsevier, 2006.

Rogers, dan Rebecca, From the Salon to the Schoolroom: Educating Bourgeois Girls in Nineteenth-Century France, University Park, Pa: Pennsylvania State University Press, 2005.

Rosemary C. Salomone, True American: Language, Identity, and the Education of Immigrant Children, Cambridge, Mass: Harvard University Press, 2010. Rouse, William B., dan Kenneth R. Boff, Organizational Simulation, New York: John Wiley \& Sons, 2005.
Routh, D. K., The experimental psychology of mental retardation, New Brunswick, N.J: AldineTransaction, 2006.

Rushton, James, dan John Derfel Turner, Education and Deprivation, Manchester: Manchester University Press, 1975.

Russell Hobby, Sharon Crabtree, The school recruitment handbook: a guide to attracting, selecting and ... termite.

Sachiko Murata and William C. Chittick, The Vision of Islam, London: I.B. Tauris, 2006.

Sahoo, F. M., Sex Roles in Transition: The Changing Dialogues between Men and Women, Dehli: Kalpaz Publications, 2004.

Samovar, Larry A., Richard E. Porter, dan Edwin R. McDaniel, Communication between Cultures, Belmont, CA: Wads w orth/C engage Learning, 2010.

San Gabriel, A.M. T. Maekawa, H. Uneyama, S. Yoshie and K. Torii 2007.

Sander, David, dan Klaus R. Scherer, The Oxford Companion to Emotion and the Affective Sciences, Oxford: Oxford University Press, 2009.

Sanderson, Catherine Ashley, Social Psychology Hoboken: Wiley, 2010, hlm. 98 .

Sarafino, Edward P, Health Psychology: Biopsychosocial Interactions, Hoboken, NJ: John Wiley, 2006, hlm. 550; Winfield, A. J., Judith A. Rees, dan Ian Smith, Pharmaceutical Practice Edinburgh: Churchill Livingstone/Elsevier, 2009.

Scher, Philip W., Perspectives on the Caribbean: A Reader in Culture, History, and Representation, Chichester, U.K.: Wiley Blackwell, 2010.

Schermerhorn, John R, Organizational Behavior, Hoboken, N.J.: Wiley, 2011. 
Schultz, Duane P., dan Sydney Ellen Schultz, Theories of Personality, Australia: Wadsworth, Cengage Learning, 2009.

Selekat, Membangun Rumah Walet Hemat Biaya, Jakarta: PT Agro Media Pustaka, 2009.

Seligman, ME.P., Positive Psychology, Positive Prevention, dan Positive Therapy. pp 3-12 in The Handbook of positive Psychology eds.

Selkirk, Alaleh K., Subjective well-being and exercise: A causal-comparative study of regular and non-regular, exercisers by Capella University, 2008.

Seyyed Hossein Nasr, Islamic Spirituality: Foundations, -New York: Crossroad, 1987.

Shadid, Wasif A. R, Islam in Dutch Society: Current Developments and Future Prospects, Kampen: Kok Pharos Publ. House, 1992.

Shaffer, David R., Social and Personality Development, Belmont, Calif: Wadsworth/Cengage Learning, 2009.

Shaleh, Abdul Rahman dan Muhbib Wahab, Psikologi suatu Pengantar dalam Perspektif Islam, Jakarta:Prenata Media,2005.

Sherman, Howard J., dan E. K. Hunt, Economics: An Introduction to Traditional and Progressive Views, Armonk, N.Y.: M.E. Sharpe, 2008.

Sherwood, L., Human physiology: From cells to systems, Belmont, CA: Brooks/Cole, Cengage Learning, 2010.

Shihab, M. Quraish, and Ihsan Ali-Fauzi, "Membumikan" Al-Al-Qur 'an: fungsi dan pecan wahyu dalam kehidupan masyarakat, Bandung: Mizan, 2002.

Shiota, Michelle N., dan James W. Kalat, Emotion, Belmont, CA:Wadsworth, Cengage Learning, 2012.
Shohov, Serge P., dan Susan Bluck. Advances in Psychology Research, Vol. 30 New York, N.Y.: Nova, 2004.

Singarimbun, Masri, Penelitian Survey, Jakarta: LP3 ES, 1982.

Slipp, Samuel, Curative Factors in Dynamic Psychotherapy, New York: McGrawHill, 1982.

Smeyers, Paul, Philosophy and Education: Accepting Wittgenstein's Challenge, Dordrecht [u.a.]: Kluwer, 1995.

Snyder, C.R., Loprez, S.J., Oxford: Oxford University Press Ltd. 2006.

Snyder, C.R., Loprez, S.J., Lopez, and Jennifer Teramoto Pedrotti, Positive psychology: the scientific and practical explorations of human strengths, Thousand Oaks, Calif. [u.a.]: SAGE, 2011.

Soerjono Soekanto, Kamus Sosiologi, Jakarta: C-V-Raj awali, 1983. Soumyen Bandyopadhyay, The humanities in architectural design: a contemporary and historical perspective, Taylor \& Francis, 2010.

Sperry, Willard Learoyd, What We Mean by Religion, Freeport, N.Y.: Books for Libraries Press, 1971.

Spradley, James P., Participant Observation, New York: Holt,

Rinehart dan Winston, 1980.

Stephen A., Mark Galizio, and Gerard J. Connors, Drug Use and Abuse, Belmont, CA: Wadsworth, 2011.

Stephen K. White, The Ethos of a LateModern Citizen, Cambridge, Mass: Harvard University Press, 2009.

Stets, Jan E., dan Jonathan H. Turner, Handbook of the Sociology of Emotions, New York, NY: Springer, 2007 ,

Stevens, Tom G, You Can Choose to Be Happy: "Rise Above" Anxiety, Anger, and Depression, with Research Evidence, Seal Beach, CA: WheelerSutton Pub. Co, 2010. 
Sunardi, tuti, Meningkatkan imunitas dan kecerdasan otak bayi-balita, Jakarta: Gramedia Pustaka Utama. 2009.

Sundt, Wilbur A., dan Richard R. Hobbs, Naval Science: An Illustrated Text for the NJROTC Student, Annapolis, Md: Naval Institute Press, 1991.

Surat Keputusan Bupati Kapuas Nomor: 15 tentang perubahan status pemukiman lokasi transmigrasi

Suryabrata, Sumadi. Belajar dan Mengajar di Perguruan Tinggi, Yogyakarta: Andi Offset.

Sweatt, J. David, Mechanisms of Memory, Amsterdam: Elsevier/Academic Press, 2010.

Sweet, William, God and argument Actexpress, Ottawa [Ont.]: University of Ottawa Press, 1999.

Syaiful Sagala, Konsep dan Makna Pembelajaran, Bandung: CV. Alfabeta, 2003.

Syibli Dalam kitab "Akaamu-l-Marjan fi Ahkamil Jan".

Taji-Farouki, S., Modern Muslim intellectuals and the Qur'an, Oxford [u.a].: Oxford Univ Pr., 2006.

Taliziduhu Ndraha, Teori Budaya Organisasi, Jakarta:Rineka Cipta, 2004.

Taylor, Robert Joseph, James S. Jackson, dan Linda M Chatters, Family Life in Black America, Thousand Oaks Calif.: Sage publ, 1997.

Tilbury, Daniella. Education and Sustainability, Cambridge: IUCN, 2002.

Tomkins, Silvan S, Affect Imagery Consciousness: The Complete Edition. 1, New York: Springer, 2008.

Toncich, D. J., Study and Learning in the Australian University System,

Brighton, Vic: Chrystobel Engineering, 2008.

Toto Tasmara, Membudayakan Etos Kerja Islam!, Jakarta: PT. Raja Grafindo Persada, 2004.
Undang-undang RI No: 20 tahun 2003, Sistem pendidikan Nasional bab I pasal 1.

Utomo dalam Suwardi Endraswara, Penelitian Kebudayaan, Yogyakarta: Pustaka Widyatama, 2006.

Vaisutis, Justine, Indonesia: Lonely Planet travel survival kit, Melbourne [etc.]: Lonely Planet, 2007.

Vajpeyi, Dhirendra K. Deforestation, Environment, and Sustainable Development: A Comparative Analysis, Westport, Conn. [u.a.]: Praeger, 2001.

Verhagen, Peter J., Herman M. Van Praag, Juan Jose Lopez-Ibor, John Cox, dan Driss Moussaoui, Religion and Psychiatry Beyond Boundaries, Chichester: John Wiley \& Sons, 2009, http://public.eblib.com/EBLPublic /PublieView.do?ptiID=470062, him. 359.

Watson, David, Mood and Temperament, New York, NY [u.a.]: Guilford Press, 2000.

Weinberg, Robert S., dan Daniel Gould, Foundations of Sport and Exercise Psychology, Champaign, Ill: Human Kinetics, 2007.

Weiner, Bernard, Human Motivation: Metaphors, Theories, and Research, London [u.a.]: Sage, 1996.

Weiner, Irving B., Handbook of Psychology and Educational Psychology, Hoboken, NJ: Wiley, 2003,

Weiten, Wayne, Psychology: Themes and Variations, Australia: Wadsworth Cengage Learning, 2011.

White, Nicholas, A Brief History of Happiness, Malden: Blackwell, 2007.

Whitten, Tony, Transmigration and the Environment in Indonesia: The Past, Present, and Future, Gland: Uni Internasional untuk Konservasi Alam dan Sumber Daya Alam, 1987.

Wibowo, Agus, Pendidikan Karakter: Strategi Membangun Karakter Bangsa 
Berperadaban-

cet.

I,

Yogyakarta: Pustaka Pelajar, 2012.

Wierzbicka, Ann a, Emotions Across Languages and Cultures: Diversity and Universals, Cambridge [u.a.]: Cambridge Univ. Press [u.a.], 1999.

Wigfield, Allan, dan Jacquelynne S. Eccle, Development of Achievement Motivation, San Diego: Academic Press, 2002. http ://www. engineeringvill age. co $\mathrm{m} /$ controller/servlet/OpenURL?ge nre $=$ book\&isbn $=9780127500539$.

William C. Chittick trans. Faith and Practice of Islam: Three Thirteenth Century Sufi Texts, Albany NY: State University of New York Press, 1992.

William P. Brown, The Ethos of the Cosmos: The Genesis of Moral Imagination in the Bible, Grand Rapids, Mich. [u.a.]: Eerdmans, 1999.

Wong, Roderick, Motivation: A Biobehavioural Approach, Cambridge [gb]: Cambridge University Press, 2000.

Woodin, M. A., \& Maffei, A., Inhibitory synaptic plasticity, New York: Springer Verlag, 2010.

Wootton, S., Home, T., \& Wootton, S., Strategic thinking: A step-by-step approach to strategy and leadership, Philadelphia: Kogan Page Limited, 2010.

WoreII, Judith, Encyclopedia of Women and Gender: Sex Similarities and Differences and the Impact of Society on Gender, San Diego, Calif: Academic, 2001.

Workman, Lance, dan Will Reader, Evolutionary Psychology: An Introduction, Cambridge [u.a.]: Cambridge Univ. Press, 2006.

World Congress on Medical Physics and Biomedical Engineering <2006, Sail>, World Congress on Medical Physics and Biomedical Engineering 2006 6, Berlin: Springer, 2007.

Yang, Guoshu, Progress in Asian Social Psychology: Conceptual and Empirical Contributions ,Westport, Conn. [u.a.]: Praeger, 2003.

Young, M. J. L., John Derek Latham, and Robert Bertram Serjeant, Religion, Learning and Science in the Abbasid Period, Cambridge: Cambridge University Press, 1990.

Yow, Valerie Raleigh, Recording Oral History: A Guide for the Humanities and Social Sciences, Walnut Creek, CA: AltaMira Press, 2005,

Zan Meyer Goncalves, Sexuality and the Politics of Ethos in the Writing Classroom, Carbondale: Southern Illinois University Press, 2005.

Zarate-Hoyos, G., New perspectives on remittances from Mexicans and Central Americans in the United States, Kassel: Kassel Univ. Press, 2007.

Abu Musa al-Ash'ari, the Prophet (SAW) said, 'Believers are like the different parts of a building, each one supporting the other.' Then he demonstrated what he meant by interlocking his fingers. (Al-Bukhari and Muslim).

Akhter, Shamim. Faith \& Philosophy of Islam (Delhi: Kalpaz Publications, 2009), hlm. 50;

Cameron, Kim S., and Gretchen M. Spreitzer. The Oxford Handbook of Positive Organizational Scholarship (New York: Oxford University Press, 2012), hlm. 178.

Chapman, Laura, and John West-Burnham. Education for Social Justice: Achieving Wellbeing for All (London: Continuum, 2010), hlm. 86

Cornell, Vincent J. Voices of Islam. Westport, Conn: Praeger Publishers, 2007.

http://ebooks.greenwood.com/browse/ 
indexj

$\underline{\mathrm{sp}}$ ? $\mathrm{x}=\mathrm{C} 8733 \& \mathrm{bc}=\mathrm{EC} 8733 \& \mathrm{p}=67$,

hlm. 163. Delle Fave, Antonella,

Fausto Massimini, and Marta Bassi.

Psychological Selection and Optimal

Experience Across Cultures Social

Empowerment Through Personal

Growth.Dordrecht: Springer

Science+Business Media B.V., 2011.

Hlm. 200.

Dewe, Philip, and Cary Cooper. Well-Being and Work: Towards a Balanced Agenda: Psychology for Organizational Success (New York, USA: Palgrave, 2011), hlm. 65.

Eid, Michael, and Larsen, Randy J. The Science of Subjective Well-Being. Guilford Pubn, 2008. Him. 364.

Georgas, James. Families Across Cultures: A 30-Nation Psychological Study. Cambridge: Cambridge Univ. Press, 2006.

<http://catdir.loc.govicatdir/enhance ments/fy0702/2006297165-d.html>. hlm. 78

Grzyma•la-Moszczyriska, Halina. Religion, Psychopathology and Coping (Amsterdam: Rodopi, 1996), hlm. 196.

Mababaya, Mamarinta. The Role of Multinational Companies in the Middle East: The Case of Saudia Arabia. Univ.of Westminster, Diss.-London, 2002, him. 322.

Misrawi, Zuhairi, Mira Rainayati, and Anjelita Noverina. Al-Quran kitab toleransi: tafsir tematik Islam rahmatan (Jakarta: Pustaka Oasis, 2010), hlm. 40.

Rikoon, J. Sanford. Rachel Calofs Story Jewish Homesteader on the Northern Plains. Bloomington: Indiana Univ. Press, 1995, hlm. 109.

Schulz, Richard. Encyclopedia of Aging 1. (A-K] . (New York: Springer, 2006), hlm. 1147.

Selin, Helaine, and Gareth Davey. Happiness Across Cultures Views of
Happiness and Quality of Life in Non-

Western Cultures. Dordrecht:

Springer, 2012.

http://dx.doi.org/10.1007/978-94-0072700-7, hlm.390-391. 
